Miscellaneous Publication 160

\title{
ACTIVE FAULTING AND SEISMIC HAZARDS IN ALASKA
}

R.D. Koehler and G.A. Carver
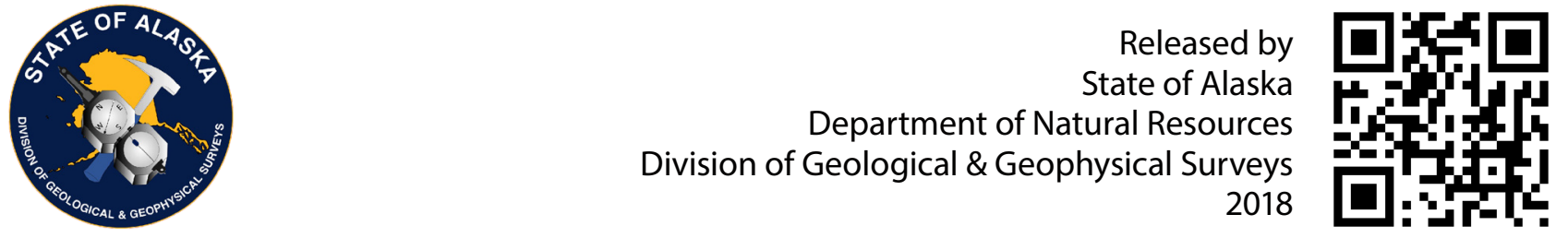
Cover. The Denali fault is clearly expressed in the landscape by linear valleys, uphill-facing scarps, and sag ponds where it projects into Denali National Park immediately west of the Parks Highway. The fault poses a significant seismic hazard to south-central and Interior Alaska and was the source of the M7.9 November 3, 2002 Denali fault earthquake. Photo credit: Rich Koehler. 


\section{ACTIVE FAULTING AND SEISMIC HAZARDS IN ALASKA}

R.D. Koehler and G.A. Carver

Miscellaneous Publication 160

State of Alaska

Department of Natural Resources

Division of Geological \& Geophysical Surveys 


\section{STATE OF ALASKA}

Bill Walker, Governor

\section{DEPARTMENT OF NATURAL RESOURCES}

Andrew T. Mack, Commissioner

DIVISION OF GEOLOGICAL \& GEOPHYSICAL SURVEYS

Steve Masterman, State Geologist and Director

Publications produced by the Division of Geological \& Geophysical Surveys (DGGS) are available for free download from the DGGS website (dggs.alaska.gov). Publications on hard-copy or digital media can be examined or purchased in the Fairbanks office:

Alaska Division of Geological \& Geophysical Surveys 3354 College Rd., Fairbanks, Alaska 99709-3707

Phone: (907) 451-5010 Fax (907) 451-5050

dggspubs@alaska.gov |dggs.alaska.gov

DGGS publications are also available at:

Alaska State Library,

Historical Collections \& Talking Book Center

395 Whittier Street

Juneau, Alaska 99811

Alaska Resource Library and Information Services (ARLIS)

3150 C Street, Suite 100

Anchorage, Alaska 99503

\section{Suggested citation:}

Koehler, R.D., Carver, G.A., and Alaska Seismic Hazards Safety Commission, 2018, Active faults and seismic hazards in Alaska: Alaska Division of Geological \& Geophysical Surveys Miscellaneous Publication 160, 59p.

http://doi.org/10.14509/29705
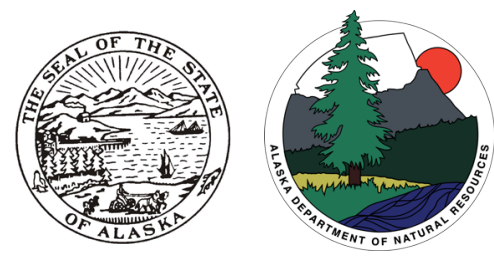


\section{CONTENTS}

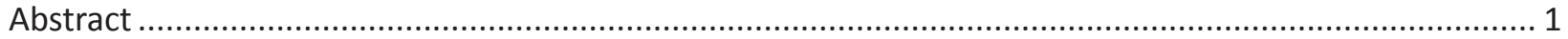

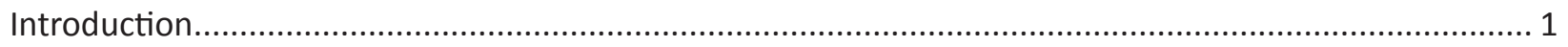

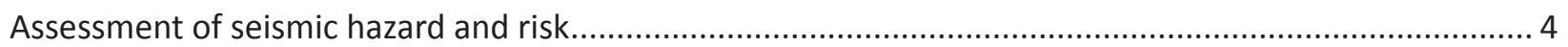

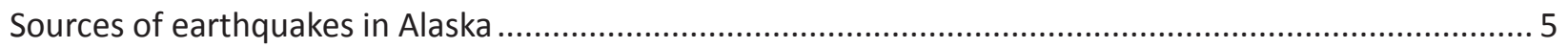

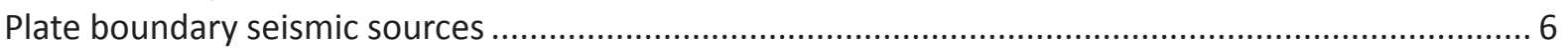

Alaska-Aleutian subduction zone and Alaska Peninsula source region ......................................... 6

Fairweather-Queen Charlotte fault system and southeastern Alaska source region ...................... 9

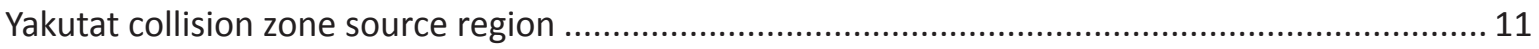

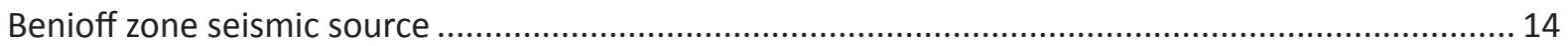

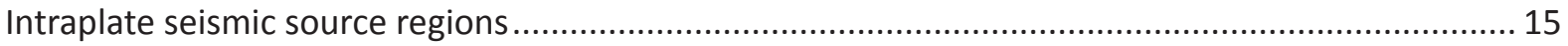

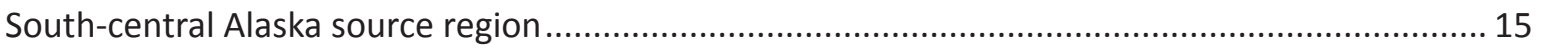

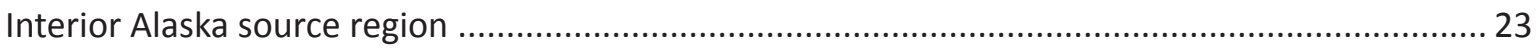

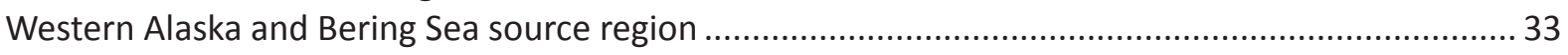

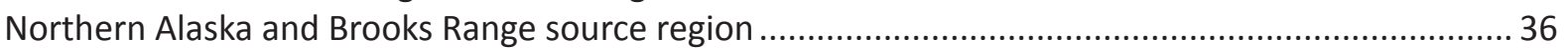

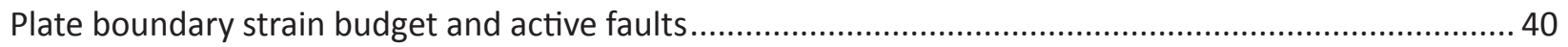

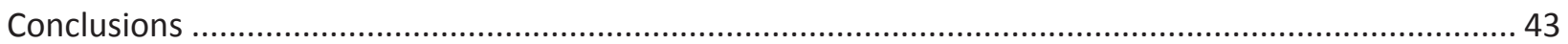

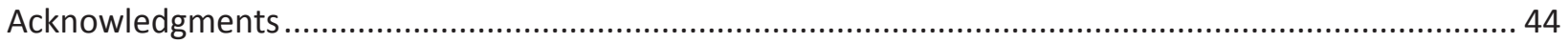

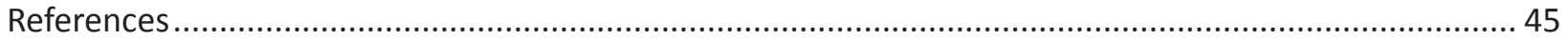

\section{FIGURES}

Figure 1. Distribution of Quaternary faults in Alaska from Quaternary fault and fold database for Alaska and general boundaries of seismic source regions in Alaska ................................................... 3

Figure 2. Date and magnitude of earthquakes in historic rupture zones along the Alaska-Aleutian subduction zone and Prince William Sound region of the eastern Alaska-Aleutian subduction zone ... 7

Figure 3. Tectonic map of southeastern Alaska, showing rupture patches of historic earthquakes .......... 10

Figure 4. Faults of the Chugach-St. Elias fold-and-thrust belt along the southern coast of Alaska

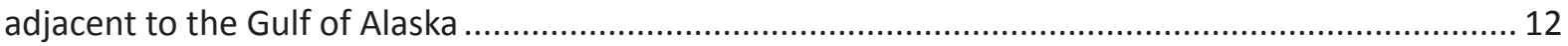

Figure 5. Map of the south-central Alaska source region, showing known active and potentially

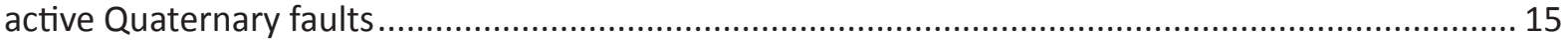

Figure 6. Lidar-derived hillshade map and slope map of the Castle Mountain fault................................ 18

Figure 7. Map of the Cook Inlet area, showing active and potentially active faults .................................. 19

Figure 8. Map of the Pass Creek fault along the northern margin of the Susitna basin .......................... 22

Figure 9. Photographs of tectonic scarps along the Pass Creek fault ..................................................... 23

Figure 10. Photographs of unnamed lineament south of the Pass Creek fault ....................................... 24

Figure 11. Map of the interior Alaska source region ........................................................................ 25

Figure 12. Map of the Denali fault and previously reported slip rate estimates ..................................... 26

Figure 13. Aligned mounds along the Salcha River seismic zone ......................................................... 31

Figure 14. View to the east of prominent side-hill scarp associated with the Dall Mountain fault............. 32

Figure 15. Map of the Bristol Bay and Yukon-Kuskokwin Delta area, showing known active and potentially active Quaternary faults.

Figure 16. Map of the Seward Peninsula area in the northern part of the Western Alaska and Bering Sea source region, showing known active and potentially active Quaternary faults .................... 34

Figure 17. Photograph of the view to the southwest along the Kaltag fault .......................................... 35

Figure 18. Map of the eastern part of the Northern Alaska and Brooks Range source region showing known active and potentially active Quaternary faults............................................................. 37

Figure 19. Photographs along the projection of the Kobuk fault .......................................................... 39

Figure 20. Quaternary fault map of Alaska and plot of combined geologic, paleoseismic, and geodetic shortening observations..... 



\title{
ACTIVE FAULTING AND SEISMIC HAZARDS IN ALASKA
}

\author{
R.D. Koehler ${ }^{1}$ and G.A. Carver ${ }^{2}$
}

\begin{abstract}
Alaska is the most seismically active region of the United States and large, frequent earthquakes pose significant seismic hazards to the state's infrastructure and inhabitants. Despite the risks associated with high rates of tectonic activity, geologic information on the relative activity of Quaternary faults is sparse. This report is designed to provide guidance for future earthquake research in Alaska, serve as a resource for seismic hazard studies, and complement the Alaska Quaternary fault database (Koehler and others, 2012a; Koehler, 2013). It summarizes the current state of knowledge pertaining to the paleoseismic characteristics of active faults throughout the state and represents the first comprehensive compilation of paleoseismic data for Alaska. The report is organized into eight seismic source regions, and includes unpublished observations from many active faults briefly visited during field campaigns associated with ongoing infrastructure studies of the Alaska Division of Geological \& Geophysical Surveys. In a summary report of this nature, it is inevitable that some information might have been overlooked. Although additional future paleoseismic characterization of active faults is needed to adequately address seismic hazards and risk in the state, the information presented here contributes to the core charter of the Alaska Seismic Hazards Safety Commission by providing data that will ultimately lead to better hazard evaluations and mitigation practices.
\end{abstract}

\section{INTRODUCTION}

Alaska experiences more earthquakes than any other state in the nation and is one of the most seismically active regions of the world (fig. 1A). Since the advent of instrumental monitoring of global seismicity, 11 percent of the world's earthquakes have occurred in Alaska. During the last century two of the ten largest earthquakes in the world and nine of the ten largest earthquakes in the United States were in Alaska. Offshore faults in Alaska are also active sources of large tsunamis that pose hazards to the circum-Pacific region.

Seismic hazards include a number of physical phenomena generated during earthquakes that can adversely affect people, their activities, and the human environment. The most common and widespread seismic hazard is strong ground motion, the shaking felt during an earthquake. Other seismic hazards include surface fault displacement; earthquake-triggered landslides and slope failures of various types including snow avalanches; liquefaction and other kinds of ground failure; subsidence; seiches; and tsunamis (McCalpin, 2009; Reiter, 1995).

Seismic hazard maps showing the probability of exceedance of several spectral ground motion metrics such as peak ground acceleration during future earthquakes in Alaska have been published by the U.S. Geological Survey (Wesson and others, $2007,1999)$ and are presently awaiting update. These maps, and probabilistic seismic hazard estimates in general, are highly dependent on historical seismicity and accurate paleoseismic information related to the timing and recurrence of past earthquakes as well as slip rates for individual faults (Field and others, 2013; Youngs and Coppersmith, 1985; Wesnousky, 1986; Frankel and others 2002; Cornell, 1968).

Yeats (2012) and Plafker and others (1994a) provide regional syntheses of earthquake geology and

\footnotetext{
${ }^{1}$ Alaska Division of Geological \& Geophysical Surveys, 3354 College Road, Fairbanks, AK 99709-3707; now at Nevada Bureau of Mines and Geology, Mackay School of Earth Science and Engineering, University of Nevada, Reno, 1664 North Virginia Street, MS 178, Reno, NV 89557

${ }^{2}$ Carver Geologic, Inc., P.O. Box 52, Kodiak, Alaska 99615
} 
active faults in Alaska. The Alaska Quaternary Fault and Fold database (Koehler, 2013; Koehler and others, 2012a) has made mapping of fault locations available in a digital format for use in seismic hazards assessment (fig. 1A); however, detailed rupture characteristics for most faults are not accurate enough for characterizing seismic risk. In particular, geologic information on the style of deformation, timing of earthquakes, and slip rates of Quaternary faults are poorly constrained for many faults. The existing geologic and paleoseismic data from the published literature, government reports, maps, and academic theses have not previously been synthesized into one document.

In this paper we introduce some basic principles and input parameters relevant to the assessment of seismic hazards and risk followed by a summary of historical seismicity and paleoseismic information related to seismic sources (such as active faults) that contribute to seismic hazards in different regions of Alaska. In general, this report describes structures (faults and folds) as active or potentially active if they show evidence for the occurrence of earthquakes and/or surface deformation in the Quaternary period (geological observations) to contemporary time (instrumentally recorded seismic and geodetic observations). For engineering geologic applications, seismic sources are variably defined as "active" depending on the purpose of a particular project, and these definitions are described in more detail in the following section. The summary of information is intended to complement the Quaternary fault map of Koehler (2013), and readers are referred to the topographic, shaded relief, and satellite base layers in that on-line database for more detailed geographic information as well as summaries of paleoseismic parameters (dip, slip sense, etc). Readers are encouraged to view the paper alongside the digital database (http://dggs.alaska.gov/pubs/id/24956) for maximum understanding.

For descriptive purposes, we divided the state into eight physiographic regions and separated inter- plate and intraplate sources (fig. 1B). These regions are similar to regions developed by the State of Alaska Division of Community and Regional Affairs and used in the State Hazard Mitigation Plan (Alaska, State of, 2013), but are generalized to reflect regional neotectonic patterns and processes. Interplate boundary source regions include: (1) the Alaska-Aleutian subduction zone and Alaska Peninsula source region, which extends along the southern coast from the Gulf of Alaska to the western end of the Aleutian Islands; (2) the Queen Charlotte-Fairweather fault and southeastern Alaska source region, which extends from southern southeast Alaska to Yakutat; (3) the Yakutat Collision zone/Chugach Mountains source region, which extends along the northern margin of the Gulf of Alaska; and (4) the Benioff zone, representing the down-dip subduction margin beneath southern Alaska. While the Benioff zone represents a planar zone of intraslab seismicity within the down-going Pacific plate along the Alaska-Aleutian subduction zone, it is considered an interplate source in this paper because the upper part of the zone represents the boundary between the Pacific and North American plates.

Intraplate source regions include: (5) southcentral Alaska, (6) interior Alaska, (7) northern Alaska and the Brooks Range, and (8) western Alaska and Bering Sea. The south-central subregion is bound on the north and east by the Alaska Range and Wrangell Mountains, respectively, and includes the western Alaska Range, Cook Inlet, Susitna basin, Talkeetna Mountains, the northern part of the Kenai Peninsula, and Copper River basin. The interior Alaska subregion includes the Yukon Flats, Yukon-Tanana upland, Tanana lowland, northern Alaska Range, and the Kuskokwim Mountains and Kuskokwim River basin. The northern Alaska subregion includes the Brooks Range, North Slope, and Beaufort Sea shelf areas. The Seward Peninsula, Yukon-Kuskokwim Delta, Kilbuck Mountains, and Bering and Chukchi Sea shelves comprise the western Alaska subregion. 


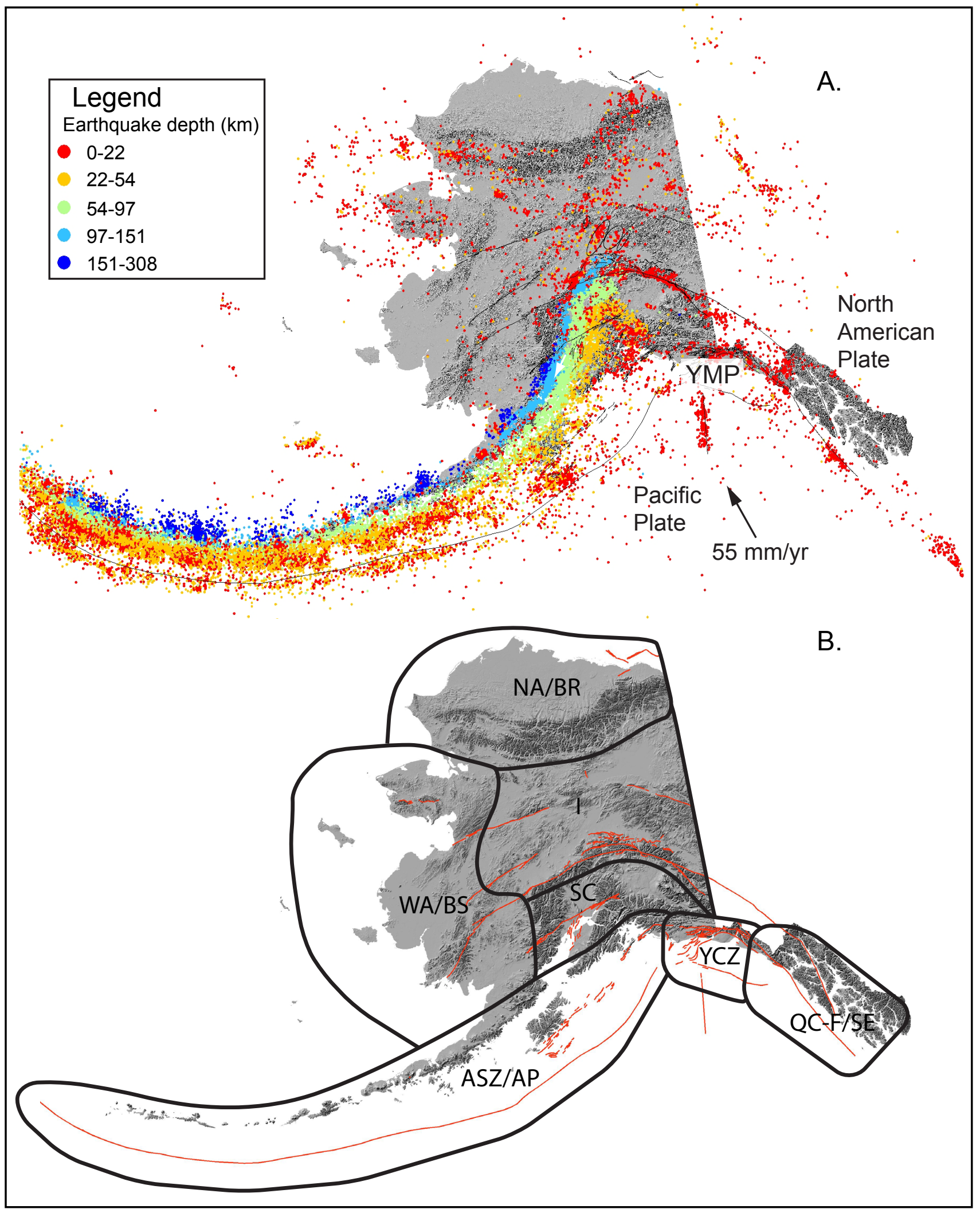

Figure 1. A. Distribution of Quaternary faults in Alaska (black lines) from Quaternary fault and fold database for Alaska (Koehler, 2013; Koehler and others, 2012). Yellow circles denote crustal seismicity from 1980-2011. B. General boundaries of seismic source regions in Alaska used in this paper. Plate bound-ary source regions include: ASZ/AP = Alaska-Aleutian subduction zone and Alaska Peninsula, QC-F/SE = Queen Charlotte-Fairweather fault and southeastern Alaska, YCZ = Yakutat collision zone. Intraplate seismic source regions include: I = Interior Alaska, NA/BR = Northern Alaska and Brooks Range, SC = South-central Alaska, WA/BS = Western Alaska and Bering Sea. Benioff zone is in the subsurface and is not labeled. Red lines show active faults. 


\section{ASSESSMENT OF}

\section{SEISMIC HAZARD AND RISK}

Seismic hazards and risks vary greatly from place to place across the state at both regional and local scales. The identification and characterization of seismic hazards regionally and locally is therefore fundamental to the development of effective approaches to hazard mitigation and risk reduction. Identification and characterization of seismic hazards is based on integrating many types of observational and theoretical information drawn from a range of disciplines including geology, geodesy, geophysics, seismology, paleoseismology, and geomorphology, among others. The process of collecting the information required to facilitate effective hazard mitigation is specific to each of the different seismic hazards and to the site and region under consideration.

The probability that seismic hazards will adversely impact people, buildings, and other engineered structures, lifelines, and other elements of the human environment constitute seismic risk. Seismic risk reflects both the likelihood and the severity of the hazard and also incorporates the vulnerability of people and the built environment. Two general categories of seismic hazard analysis (SHA) are commonly used in seismic risk assessment: deterministic (DSHA) and probabilistic seismic hazard analysis (PSHA). DSHA focuses on defining the worst credible case without regard to the time probability of occurrence, exposure time, or design life of the facility under consideration. In PSHA, the hazards at a site are specified as the worst effects (for example, ground motions) that are statistically likely to occur in a specified time interval in terms of their probability of exceedance (Somerville and Moriwaki, 2003; Kramer, 1996; Abrahamson, 2006; Reiter, 1990). Application of risk assessment software (most commonly Hazus) has improved loss estimation and earthquake vulnerability assessment of infrastructure (Nishenko and others, 1998).

Databases of mapped surface fault traces and rupture parameters for earthquake sources provide important data for the development of community fault models. In California, long-term earthquake rupture forecasts have been based on 3D fault geometry databases that use a combination of surface fault traces and other geological and geophysical data (Field and others, 2009; Field and others, 2013; Plesch and others, 2007). Rupture forecast models typically use ground motion prediction equations (GMPE's) to estimate the probability of exceedance of the level of ground motion over a certain time interval at a particular site for a variety of sources in an area. Physics based 3D ground motion simulations that use multiple rupture variations (hypocenter location, slip distribution) to calculate synthetic seismograms and probabilistic seismic hazard curves indicate that rupture directivity and basin response can lead to estimates of stronger ground shaking than those estimated with conventional GMPE's (Graves and others, 2011). These types of analyses are precluded in Alaska by limited available data, however, some of these techniques may be applicable in the future.

Determination of seismic risk is based on adequate identification and characterization of the hazards that are present in a region, and the exposure of sites to the hazards (often a consequence of their location). Assessment of seismic risk incorporates geological and geophysical information about seismic hazard with consideration of the design, location, and characteristics of the built environment including local geology and physical properties, especially the characteristics of soils, proximity to hazards, engineering and architectural specifications, and the quality and resistance (fragility) of construction.

Foremost in the study of seismic hazards is the identification of the locations and nature of earthquake sources. Sources of earthquakes may be faults that are observable at the earth's surface but many (e.g., blind faults) do not reach the surface. Assessment of activity of surface faults, the surficial, secondary effects of blind faults, and definition of fault displacement parameters is the principal focus of the discipline of paleoseismology (McCalpin, 2009). 
Evaluation of deep seismic sources, such as those in subduction Benioff zones, is performed principally by a seismologist. The sense of movement, orientation and distance of the fault from the site of interest, amount of slip during single events, direction of fault rupture propagation, level of fault activity, and other fault displacement parameters act in combination to contribute to seismic hazard. Other factors important to seismic hazard assessment can include the nature of the Earth's crust between the causative fault and the site of interest, local soil conditions and topography, the proximity of the site to water bodies that could generate tsunamis or seiches, and proximity to hill slopes prone to earthquake-triggered failure.

For most engineering geologic applications a fault is classified as active and interpreted to have the potential to generate future earthquakes if it has experienced displacement during Holocene time (the last 11,000 years) (Slemmons and McKinney, 1977; Hart, 1980). For some critical structures longer timeframes are used as the basis for defining faults as active. For example, the definition of a "capable fault" for nuclear power plant siting is a fault that has had "movement at or near the ground surface at least once within the past 35,000 years or movement of a recurring nature within the past 500,000 years" (U.S. Nuclear Regulatory Commission, 1997). Blind faults (faults not associated with discreet surface displacement) are considered active if they have generated observable secondary effects at the surface, such as tilting or disruption of drainages, during the Holocene or if they produce macro-seismicity that instrumentally demonstrates a direct relationship with the causative fault.

\section{SOURCES OF EARTHQUAKES IN ALASKA}

Alaska is located on the North American plate and several recently recognized microplates (Freymueller and others, 2008; Chapman and others, 2008; Haeussler, 2008; Ruppert and others, 2008). The Pacific plate is moving $-55 \mathrm{~mm} / \mathrm{yr}(-2.2 \mathrm{in} / \mathrm{yr})$ to the northwest relative to the North American plate and associated microplates along a system of major faults that extend along the southeastern and southern coasts of Alaska. These faults include two of the largest and most active fault systems in the world, the Queen Charlotte-Fairweather transform fault system and the Alaska-Aleutian subduction zone (fig. 1A). These plate boundary structures are roughly connected by the Yakutat microplate collision zone (Chugach-St. Elias thrust system), which extends along the northern side of the Gulf of Alaska, both offshore and on land. Plate boundary forces apply stress to the crust for more than $1,000 \mathrm{~km}(620 \mathrm{mi})$ north of the plate boundary into interior and northern Alaska. In the interior, deformation is accommodated by the Denali fault, thrust faults along the northern flank of the Alaska Range, northeast-trending seismic zones near Fairbanks, and many other poorly understood faults. Rates of deformation in the extreme northern and northwestern parts of the state are below the resolution of modern GPS networks; however, diffuse seismicity indicates active deformation. Only a few Quaternary faults have been identified in these areas, and unmapped active faults are likely present.

Considerable research in Alaska has focused on the characterization of the eastern Alaska-Aleutian subduction zone, particularly the 1964 rupture segment, and the Denali fault. Seismologists have also produced considerable information regarding the Alaska-Aleutian Benioff zone. Little is known about the rupture history and characteristics of the central and western Aleutian subduction zone. Additionally, observations on Quaternary activity are limited to reconnaissance studies in most cases, and detailed paleoseismic studies are few for faults in the Yakutat microplate collision zone as well as most of the intraplate faults in the northern, northwestern, and interior parts of the state.

In the following sections, we describe fault physiography, earthquake geology, seismicity, historical earthquakes, and paleoseismic information (where available) associated with major plate boundary seismic zones, as well as lesser studied intraplate regions. 


\section{PLATE BOUNDARY SEISMIC SOURCES}

Alaska-Aleutian subduction zone and Alaska Peninsula source region

The Alaska-Aleutian subduction zone is the nearly 4,000-km-long (2,485-mi-long) convergent plate boundary between the Pacific plate and the North American plate. It extends from Cape Suckling west to the Kamchatka Peninsula in Russia (fig. 2A). Active seismicity indicates where and how the Pacific plate is subducting beneath the North American plate (Davies, 1975; Davies and House, 1979; Page and others, 1991), and shows steeply dipping subduction in the west and gently dipping subduction in the east. Slab seismicity abates at approximately $200 \mathrm{~km}(125 \mathrm{mi})$ depth, reflecting the down-dip extension of the Pacific plate. Convergence rates between the Pacific and North American plates in southern Alaska and along the Aleutian arc increase westward from 55 to $75 \mathrm{~mm} /$ yr (2.2 to $3 \mathrm{in} / \mathrm{yr})$ in the east and west, respectively (DeMets and others, 1990).

Most of the Alaska-Aleutian subduction zone ruptured in a sequence of great earthquakes in the mid-20th century (Nishenko and Jacob, 1990). These great earthquakes include the $1938 \mathrm{M}_{\mathrm{W}} 8.3$ Alaska Peninsula earthquake (Johnson and Satake, 1994), the $1946 \mathrm{M}_{\mathrm{W}}$ 8.6 Unimak earthquake (López and Okal, 2006; Okal and Hébert, 2007), the $1957 \mathrm{M}_{\mathrm{W}}$ 8.6 Fox Islands earthquake (Johnson and others, 1994), the $1964 \mathrm{M}_{\mathrm{W}} 9.2$ great Alaska earthquake (Ichinose and others, 2007; Plafker, 1969; Christensen and Beck, 1994), and the $1965 \mathrm{M}_{\mathrm{W}} 8.7$ Rat Islands earthquake (Beck and Christensen, 1991) (fig. 2A). All of the historic great subduction earthquakes spawned transPacific tsunamis. Two of these subduction earthquakes are among the ten largest to occur worldwide in the past 100 years; the 1964 great Alaska earthquake is the second largest. In addition to the great earthquakes of the historic sequence, parts of the 1957 and 1965 rupture areas re-ruptured, generating M 7.9 earthquakes in 1986 (Andreanof earthquake), 1996 (Adak earthquake), and 2014 (Rat Islands earthquake) (Boyd and Nabelek, 1988; Alaska Earthquake Center, 2016). The only sections of the Alaska-Aleutian subduction zone that remain historically unbroken are an approximately 200-km-long (125-mi-long) section at the western end of the Alaska Peninsula (Shumagin segment) and a short section in the Unalaska area.

Based on the historic earthquake rupture zones, the Alaska-Aleutian subduction zone has been subdivided into multiple segments including the Yakutaga-Yakutat, Prince William Sound, Kodiak Island, Alaska Peninsula Shumagin Islands, Unimak Island, Fox Islands, Andreanof Islands, Delarof Islands, Rat Islands, Near Islands, and Russia's Komandorski Islands (Nishenko and Jacob, 1990). Marine geophysical observations indicate that distinct structural blocks occur along the margin and are separated by asperities that may influence the location of seismic moment release (Ryan and Scholl, 1993). A topic of ongoing research is whether these segments remain fixed in time or if multi-segment ruptures are possible (Briggs and others, 2014a).

The eastern Alaska-Aleutian subduction zone was the source of the $1964 \mathrm{M}_{\mathrm{W}} 9.2$ great Alaska earthquake, which ruptured about $800 \mathrm{~km}$ (500 mi) of the plate boundary megathrust from the southern end of Kodiak Island to near Cape Yakataga (fig. 2A). The earthquake was generated by as much as $25 \mathrm{~m}$ (82 ft) of horizontal displacement on the megathrust beneath Prince William Sound (Parkin, 1969). Several subsidiary upper plate thrust faults, including the Patton Bay and Hanning Bay faults on Montague Island and their southern extensions on the sea floor also ruptured during the earthquake. Uplift of the sea floor from slip on these faults was the primary source of the destructive tsunami generated during the 1964 earthquake (Plafker, 1969); however, Seward, Valdez, and other communities were also affected by submarine landslides and local tsunamis that arrived before the tectonic waves caused major damage (Lemke, 1967; Lander, 1996; Nicolsky and others, 2013; Suleimani and others, 2010). Studies by Kulikov and others (1998) and Ryan and others (2010) indicate that submarine landslides have occurred repeatedly through the Holocene. 
During the 1964 earthquake, dip-slip displacement on land along the Patton Bay fault was as much as $7.9 \mathrm{~m}(26 \mathrm{ft})$ and the maximum vertical component of slip on the Hanning Bay fault was $5 \mathrm{~m}(16.4 \mathrm{ft})$ (Plafker, 1967a) (fig. 2B). These displacements were predominantly reverse with a small component of left-lateral slip. Additional upper plate faults southwest and north of Montague Island including the Latouche, Cape Cleare, Bainbridge, and Montague Strait faults are inferred to have also ruptured in conjunction with the 1964 earthquake, based on seafloor displacements (Liberty and others, 2013). Based on interpretation
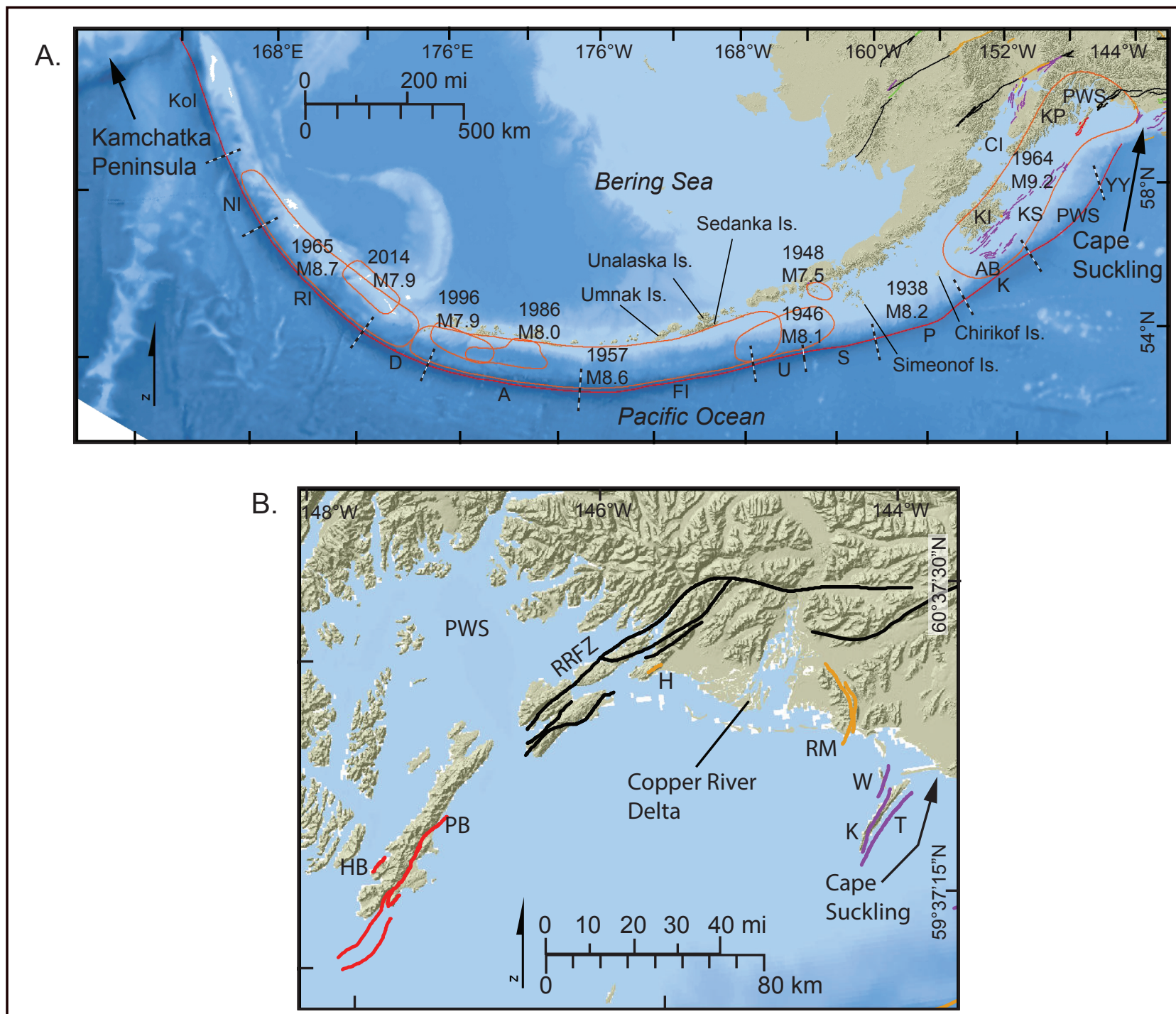

Figure 2. A. Date and magnitude of significant earthquakes in historic rupture zones (orange polygons) along the Alaska-Aleutian subduction zone (outlined in red). Data from Haeussler and Plafker (2004) and the Alaska Earthquake Center. Previously defined segment boundaries (Nishenko and Jacob, 1990) shown by dashed black lines, however questions remain in the scientific literature regarding the persistence of tectonic segments through time. The segments include: $Y Y=$ Yakataga-Yakutat, PWS = Prince William Sound, $\mathrm{K}=$ Kodiak Island, $\mathrm{P}=$ Alaska Peninsula, $\mathrm{S}=$ Shumagin, $\mathrm{U}=$ Unimak Island, FI = Fox Islands, A = Andreanof Islands, D = Delarof Islands, $\mathrm{RI}=$ Rat Islands, $\mathrm{NI}=$ Near Islands, $\mathrm{Kol}=$ Komandorski Islands. $\mathrm{Cl}=$ Cook Inlet, $\mathrm{KI}=$ Kodiak Island, $\mathrm{KP}=$ Kenai Peninsula, $\mathrm{PWS}=$ Prince William Sound, $K S=$ Kodiak Shelf fault zone, $A B=$ Albatross Bank fault zone. B. Prince William Sound (PWS) region of the eastern Alaska-Aleutian subduction zone showing active faults. $\mathrm{H}=$ Heney fault, $\mathrm{HB}=$ Hanning Bay fault, $\mathrm{K}=$ Kayak fault, $\mathrm{PB}=\mathrm{Patton}$ Bay fault, RM = Ragged Mountain fault, RRFZ = Rude River fault zone, $T=$ Tenfathom fault, $W=$ Wingham fault. Fault colors indicate relative age of activity from Koehler (2013): Historic (<150 yrs, red), latest Pleistocene and Holocene ( $<15$ ka, orange), latest Quaternary ( $<130$ ka, yellow), mid-Quaternary ( $<750$ ka, green), Quaternary (<1.6 ma, purple), and potentially active or pre-Quaternary (black). 
of seismic reflection data, Liberty and others (2013) indicate that long-term slip rates may be as high as 9 $\mathrm{mm} / \mathrm{yr}(0.4 \mathrm{in} / \mathrm{yr})$ on these structures.

Investigations related to the timing of prehistoric earthquakes based on studies of coastal marshes have been most extensively conducted along the eastern part of the subduction zone around Prince William Sound and Cook Inlet. These studies, including investigations on Montague, Hinchinbrook, Hawkins, Middleton Islands, Copper River Delta, Knik Arm, Turnagain Arm, and lower Cook Inlet provide evidence for nine great earthquakes in the last 5,000 years with a median recurrence interval of 560 years and a range of 333-875 years (Carver and Plafker, 2008, and references therein). An additional event ruptured the megathrust near Kodiak around 533-473 B.P. but apparently did not extend to the Prince William Sound area. Based on beach ridge geomorphology and stratigraphic studies along the southern Kenai Peninsula, Kelsey and others (2015) provide observations that suggest the occurrence of an earthquake between AD 1530 and 1840 along the Kenai Peninsula that did not involve the Kodiak and Prince William Sound segments to the west and east, respectively. Paleoseismic studies of lacustrine deposits in south-central Alaska indicate a mean recurrence interval for seismically induced landslides of -250 yrs., -450 yrs., -900 yrs. and -450 yrs. for the Eklutna Lake Proximal basin, Eklutna Lake distal basin, Skilak Lake, and Kenai Lake, respectively (Praet and others, 2017). Thus, damaging M 8+ earthquakes generated along the megathrust within the 1964 rupture patch are recognized as a credible seismic hazard. However, because of the long recurrence interval and recency of the 1964 earthquake, a repeat of that event is less likely in the near future.

East of the 1964 rupture area in the YakutagaYakutat segment, a series of three elevated marine terraces between Icy Bay and Cape Yakataga have been attributed to coseismic uplift due to rupture on the megathrust (Carver and Plafker, 2008). On the basis of radiocarbon analyses, Plafker and others
(1982) estimate that the terraces were coseismically elevated above sea level around 1,389-976 B.P., 2,744-2,329 B.P., and 5,919-5,586 B.P. Shennan and others (2009) evaluated paleoseismic records from sites on either side of the eastern limit of the 1964 rupture and inferred regional uplift events at -900 and $-1,500$ years ago, suggesting simultaneous rupture of the Prince William Sound and Yakataga-Yakutat segments of the megathrust. If correct, the observations indicate a rupture area -15 percent greater than the 1964 rupture, implying a correspondingly larger earthquake. In the Katalla area, Shennan and others (2014) report a pre-1964 earthquake $-500 \mathrm{cal}$ yrs B.P., which may be related to upper plate faulting independent of the megathrust along the Ragged Mountain fault (fig. 2B).

The central and western Alaska-Aleutian subduction zone (southwest of Kodiak) including the Aleutian Islands has produced intermediate and deep interplate earthquakes along the subduction zone, shallow outer-rise events near the trench, as well as seismicity associated with volcanic activity. During the last 60 years, more than 9,800 M $\geq 4$.0 earthquakes have been located in this region, including more than 2,500 moderate $(M \geq 5.0)$ earthquakes (Alaska Earthquake Center, 2016). The region averages three or four strong $(M \geq 6.0)$ earthquakes each year. There have been 64 major $(M \geq 7.0)$ events in the Aleutians, and three great events $(M \geq 8.0)$. Recent notable events include the 2010 M 6.7 Fox Islands earthquake and the 2014 M 7.9 Rat Islands earthquake, which was associated with more than 2,500 aftershocks, including 60 with $M>4.0$, the largest of which was M 6.4.

With the exception of the 20th century earthquakes, the paleoearthquake history of the central and western Alaska-Aleutian subduction zone is poorly characterized. Russian fur trader accounts indicate the occurrence of earthquakes in 1788 and 1847 in the Shumagin Islands region; however, details on these events are cryptic (Davies and others, 1981). Although an indirect proxy for earthquake ruptures, 
recent U.S. Geological Survey paleotsunami and land-level studies on islands in the Aleutians are beginning to develop information on paleoearthquake timing. On Sedanka and Umnak islands (fig. 2A), Witter and others (2014a, 2015) identified multiple sand layers in the coastal stratigraphy and driftwood logs up to $23 \mathrm{~m}(75 \mathrm{ft})$ elevation inferred to have been deposited by high-runup tsunamis. Witter and others (2015) infer that these observations indicate repeated megathrust earthquakes in the Unalaska seismic gap in the past $-2.2 \mathrm{ka}$ and based on radiocarbon analyses, suggest repeat intervals of 280-325 years. On Chirikof Island (fig. 2A), Briggs and others (2014b) documented evidence for multiple tsunamis over the past $-3.4 \mathrm{ka}$ with a repeat interval of 250-400 years. On Simeonof Island, Witter and others (2014b) did not find evidence for coseismic uplift or subsidence and suggested that late Holocene earthquakes may have been too small to perturb the onshore geologic record, possibly due to the location of the island close to the hinge line of the subducting trench.

Additional seismic sources associated with the Alaska-Aleutian subduction zone/Alaska Peninsula source region accommodate compression and flexure of the upper plate within the forearc inboard of the subduction trench. The Kodiak Shelf and Albatross Bank fault zones are predominantly offshore and roughly parallel Kodiak Island (fig. 2A). Based on GPS studies, upper crustal faulting associated with the Kodiak Shelf fault zone is responsible for about $0.75 \mathrm{~mm} / \mathrm{yr}(0.03 \mathrm{in} / \mathrm{yr})$ of uplift and $5-15 \mathrm{~mm} / \mathrm{yr}$ (0.2-0.6 in/yr) of left-lateral deformation on Kodiak Island (Carver and others, 2008b). Paleoseismic trenches along the Narrow Cape fault, part of the Kodiak Shelf fault system expressed onshore on Kodiak Island, indicate the occurrence of six or seven Holocene earthquakes with a recurrence interval of 1-2 ka (Carver and others, 2008b).

The Wingham, Tenfathom, and Kayak faults (fig. 2B) comprise a northeast-trending, northwestdipping forearc reverse fault system that bounds
Kayak Island and extends for more than $30 \mathrm{~km}(19$ mi) (Plafker, 1974). Additionally, the Heney fault and the Rude River fault zone represent the northeastern projection of the Patton Bay fault. Little is known about the paleoseismic history of these faults; however, their position and orientation in the transition zone between the Yakutat collision zone and the Alaska-Aleutian subduction zone suggest they are capable of generating large earthquakes.

\section{Fairweather-Queen Charlotte fault system and southeastern Alaska source region}

In southeastern Alaska, active seismic sources include the Fairweather-Queen Charlotte fault system, the Chatham Strait section of the Denali fault, the eastern end of the Transition fault, and other potentially active faults mapped in bedrock (fig. 3). The highly active right-lateral Fairweather-Queen Charlotte transform fault system marks the boundary between the Pacific and North American plates and constitutes the locus of much of the region's seismicity. Earthquakes are generally shallow crustal events along right-lateral strike-slip faults with more than $400 \mathrm{M} \geq 4.0$ events and 20 strong earthquakes $(M \geq 6.0)$ in the last 60 years (Alaska Earthquake Center, 2016).

The Fairweather-Queen Charlotte fault has generated several major destructive earthquakes in the last century including the $1949\left(\mathrm{M}_{\mathrm{W}} 8.1\right)$ earthquake offshore of the Queen Charlotte Islands, the 1958 Lituya Bay earthquake $\left(\mathrm{M}_{\mathrm{W}}\right.$ 7.9) on the northern part of the system, and the $1972\left(\mathrm{M}_{\mathrm{W}}\right.$ 7.3) earthquake west of Sitka (fig. 3). The Lituya Bay earthquake triggered a massive landslide into Lituya Bay that generated a 540-m-high (1,772-ft-high) wave (Miller, 1960) and the 1972 earthquake was felt to distances of nearly 1,000 km (620 mi) (Page, 1973). Two recent earthquakes, the $2012 \mathrm{M}_{\mathrm{W}} 7.7$ Haida Gwaii earthquake along the southern extension of the fault in offshore British Columbia and the $\mathrm{M}_{\mathrm{W}} 7.5$ earthquake near Craig, caused minor shaking damage and tsunami warnings (fig. 3). 


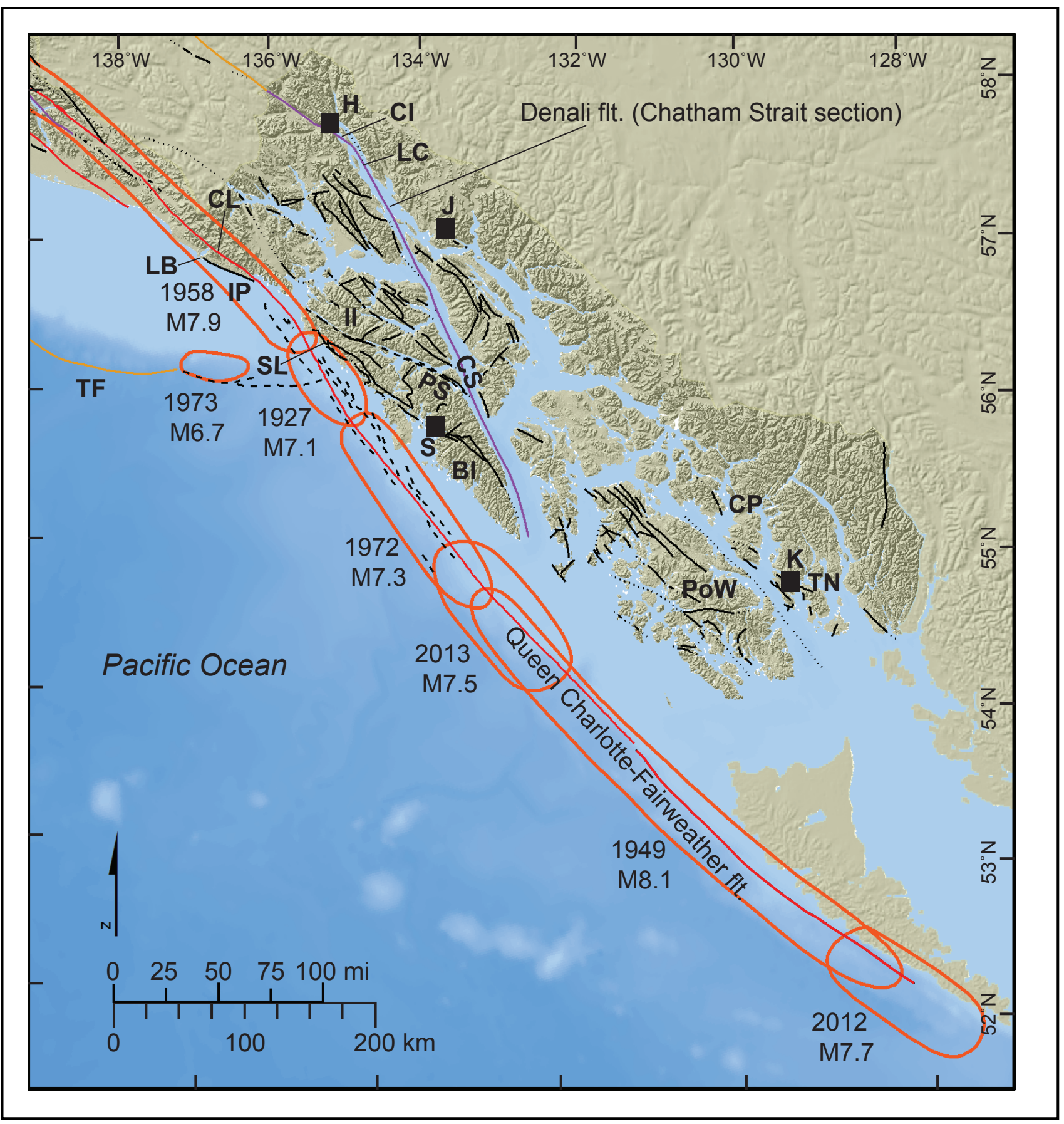

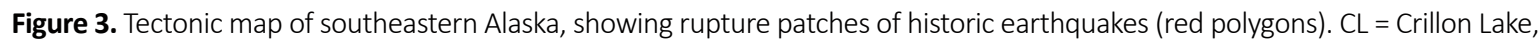
$\mathrm{BI}=$ Baranof Island, $\mathrm{Cl}=$ Chilkat Inlet, $\mathrm{CP}=$ Canoe Passage fault, $\mathrm{CS}=$ Chatham Strait, $\mathrm{H}=$ Haines, II = Idaho Inlet fault, IP = Icy Point fault, $\mathrm{J}=$ Juneau, $\mathrm{K}=$ Ketchikan, LB = Lituya Bay, LC = Lynn Canal, PoW = Prince of Wales Island, PS = Peril Strait fault, S = Sitka, SL = Sea Level fault, TF = Transition fault, TN = Tongass Narrows fault. Fault colors indicate relative age of activity from Koehler (2013); see figure 2 for definitions.

Paleoseismic field investigations have only been conducted along the 1958 rupture trace largely due to the limited on-land extent of the fault. Surface offsets of $2.4-6.5 \mathrm{~m}(7.9-21.3 \mathrm{ft})$ lateral and $>1 \mathrm{~m}(>3.3 \mathrm{ft})$ vertical have been documented and offset glacial landforms have been used to estimate a late Holocene slip rate of between 48 and $58 \mathrm{~mm} / \mathrm{yr}(2-2.3 \mathrm{in} / \mathrm{yr})$ (Tocher, 1960; Plafker and others, 1978). Recent paleoseismic trench reconnaissance and evaluation of lidar data at the north end of Crillon Lake identified 
evidence for at least three paleoearthquakes including 1958 and documented youthful stream channels right laterally deflected up to $128 \mathrm{~m}(420 \mathrm{ft})$ across the fault (Witter and others, 2017a; 2017b). Geodetic observations along the northern part of the system near Yakutat indicate a right-lateral slip rate of 42.9 $\pm 0.9 \mathrm{~mm} / \mathrm{yr}(-1.7 \mathrm{in} / \mathrm{yr})$ (Elliott and others, 2010) slightly faster than the $35.7 \pm 1.0$ to $40.0 \pm 1.0 \mathrm{~mm} /$ yr $(-1.4$ to -1.6 in/yr) reported by (Fletcher and Freymueller, 2003). Offshore bathymetric surveys and sub bottom profile data have identified several piercing points across the fault and determined a slip rate of $45-55 \mathrm{~mm} / \mathrm{yr}$ since $14 \mathrm{ka}$ (Greene and others, 2016). Assuming the largest earthquakes are constrained within segments and have similar characteristics to the historical events (characteristic earthquake behavior), the recurrence interval for large-magnitude earthquakes on the Fairweather-Queen Charlotte system is 100 to 155 years (Wesson and others, 2007). Repeat times of $-70 \mathrm{yrs}$ are possible if the entire plate rate is accommodated along the fault as is suggested by recent slip rate studies.

The Chatham Strait section of the Denali fault extends on the seafloor of Lynn Canal, Chatham Strait, and Chilkat Inlet from near the southern tip of Baranof Island to Haines (fig. 3). To the north, the fault continues on land along the Chilkat River valley. Cumulative lateral displacements of Tertiary and late Paleozoic rocks between 100 and $193 \mathrm{~km}$ (62 and $120 \mathrm{mi}$ ) have been reported (Lathram, 1964; Sonnevil, 1981; Hudson and others, 1982), but no Holocene displacements have been documented (Hudson and others, 1982) and slip parameters are unknown. Plafker and others (1994a) mapped the fault as "suspicious with possible Neogene displacement." Possible Quaternary activity is inferred based on the fault's orientation, relatively parallel to the plate boundary, and documented Quaternary activity along the fault's extension to the north near Kluane Lake (Seitz and others, 2008).

The majority of southeastern Alaska was covered in glacial ice during the latest Pleistocene, which likely removed any evidence of older earthquakes. Since that time the area has been forested by a thick Sitka spruce ecosystem. Additional faults capable of producing earthquakes likely exist along the Fairweather-Queen Charlotte fault system. These types of subsidiary faults are common along other major plate boundary strike-slip faults (such as the San Andreas fault in California and the Alpine fault in New Zealand). Multiple northwest-trending bedrock faults extend across Baranof Island including the Sea Level, Idaho Inlet, and Peril Strait faults, among others (Plafker and others, 1994a) and are optimally oriented to transfer compressional strain from the Fairweather fault to the Chatham Strait section of the Denali fault. Farther south, in the vicinity of Ketchikan, the Canoe Passage fault, Tongass Narrows fault, and multiple unnamed faults on Prince of Wales Island (Plafker and others, 1994a) might also contribute to the seismic hazard. The relative activity and seismic potential of these faults is unknown.

\section{Yakutat collision zone source region}

Along the eastern part of Alaska's southern coast, from Yakutat to Cape Suckling, the plate boundary involves the collision of the Pacific plate and Yakutat microplate with the Wrangell microplate and the North American plate (figs. 1A and 4). Here the Pacific plate boundary is defined by a complex system of offshore thrust faults, which extend onshore in the vicinity of Cape Yakataga and Icy Bay. Collectively this zone is known as the Chugach-St. Elias fold-and-thrust belt and includes the active Chaix Hills, Coal Glacier, Hope Creek, Kayak, Kosakuts, Malaspina, Miller Creek, Sullivan, and Bagley faults, the Pamplona fault zone, and several active folds including the Yaga syncline, Yakataga anticline, and White River syncline (fig. 4). The majority of these structures have the potential to generate large to great earthquakes, presenting a high seismic hazard for the northern Gulf of Alaska area. Background levels of seismicity along the coast are extremely high, with thousands of earthquakes recorded every year. 


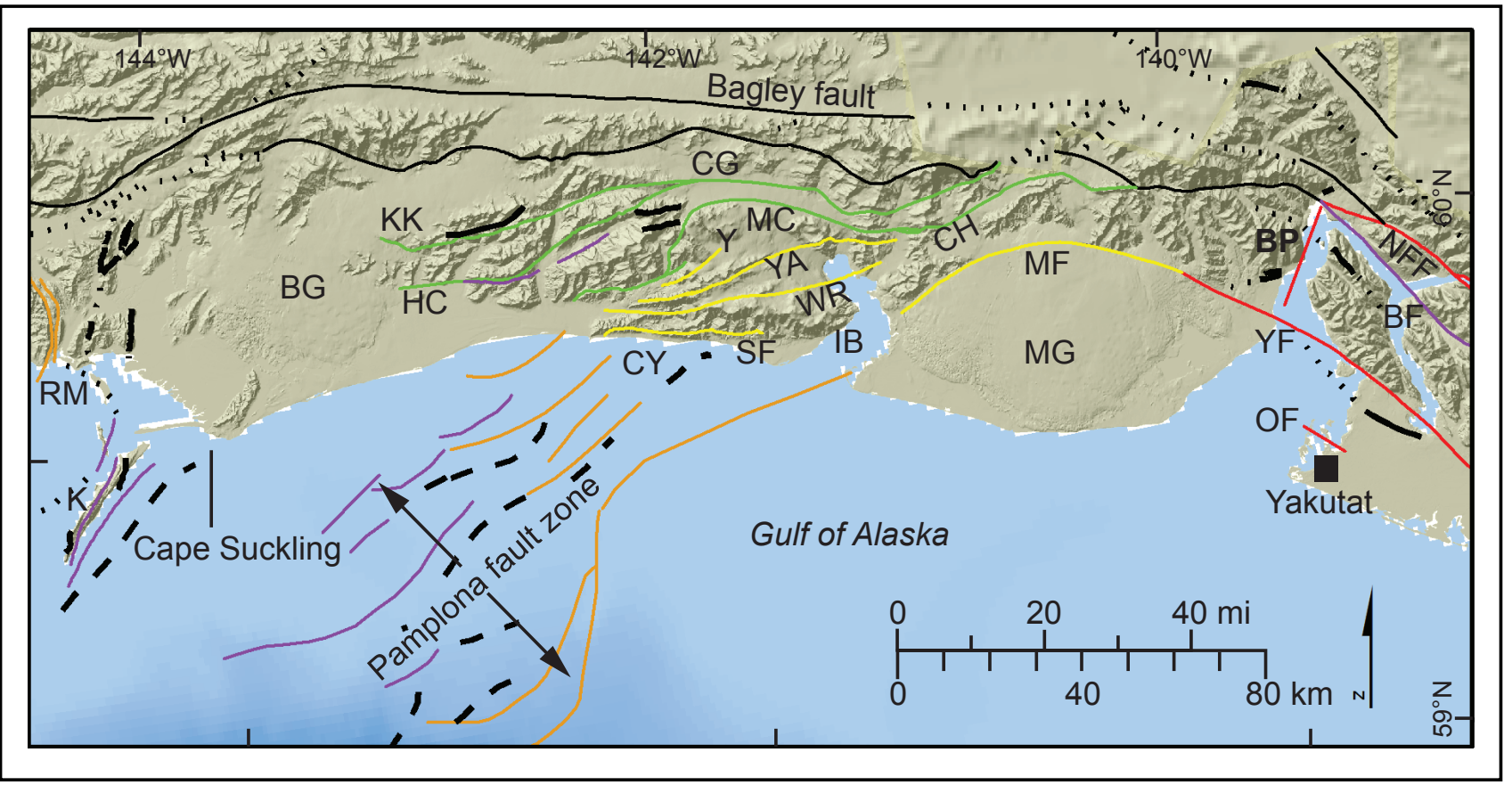

Figure 4. Faults of the Chugach-St. Elias fold-and-thrust belt along the southern coast of Alaska adjacent to the Gulf of Alaska. Fault colors indicate relative age of activity from Koehler (2013); see figure 2 for definitions. $\mathrm{K}=$ Kayak fault, BF = Boundary fault, BG = Bering Glacier, $\mathrm{BP}=$ Bancas Point fault, $\mathrm{CG}=\mathrm{Coal}$ Glacier fault, $\mathrm{CH}=$ Chaix Hills fault, $\mathrm{CY}=$ Cape Yakataga, $\mathrm{HC}=$ Hope Creek fault, IB $=\mathrm{Icy} \mathrm{Bay}, \mathrm{KK}=\mathrm{Kosa}-$ kuts fault, $\mathrm{MC}=$ Miller Creek fault, MF = Malaspina fault, MG = Malaspina Glacier, NFF = northern Fairweather fault, OF = Otmeloi fault, RM = Ragged Mountain fault, SF = Sullivan fault, WR = White River syncline, $\mathrm{Y}=$ Yaga syncline, $\mathrm{YA}=$ Yakataga anticline, $\mathrm{YF}=$ Yakutat fault.

In addition to tectonic events, earthquakes are also generated in response to glacio-isostatic processes.

Structural and stratigraphic studies across the Chugach-St. Elias fold-and-thrust belt have described the structures and kinematics involved in collision and accretion of the Yakutat terrane and uplift of the Chugach-St. Elias mountains (Plafker, 1967b; Plafker and others, 1994b; Bruhn and others, 2004; Pavlis and others, 2004; Wallace, 2008b; Meigs and others, 2008; Chapman and others, 2012). Shortening is accommodated by the formation of narrow anticlines separated by broad, flat-bottomed synclines. Earthquakes along steep thrust faults that core the anticlines are responsible for fault propagation folding; however, at present there are no paleoseimic constraints regarding the timing or recurrence of earthquakes along individual faults. Crustal seismicity is concentrated along the eastern part of the zone; however, diffuse seismicity extends to the west toward the Ragged Mountain fault.

Total shortening estimates in the Chugach-St. Elias Range, based on plate reconstructions and exhumed material, are on the order of $300 \mathrm{~km}(186$ mi) (Pavlis and others, 2004; Berger and others, 2008; Chapman and others, 2008). Minimum shortening estimates for the hanging wall of the Chugach-St. Elias thrust since the onset of Yakataga Formation deposition ( $-6 \mathrm{Ma})$, based on geologic observations and balanced cross sections, range from 36 to $82 \mathrm{~km}(22.4$ to $51 \mathrm{mi}$ ) (Wallace, 2008b; Meigs and others, 2008; Chapman and others, 2008), with the differences mainly attributed to alternative interpretations of fault displacement and the amount of thickening at depth. These observations have been used to infer minimum shortening rates of $-6.1 \mathrm{~mm} / \mathrm{yr}(-0.2 \mathrm{in} / \mathrm{yr}$ ) (Wallace, $2008 \mathrm{~b})$ and $-13-14 \mathrm{~mm} / \mathrm{yr}(-0.5-0.6 \mathrm{in} / \mathrm{yr}$ ) (Meigs and others, 2008). Meigs and others (2008) indicated that the displacement was accommodated along three main thrust sheets whose cumulative displacements decrease to the south, including Hope Creek (44 km [27 mi]), Sullivan (35 km [22 mi]), and an offshore thrust sheet (3 km [1.9 mi]). Meigs and others (2008) used these displacements with the depositional history 
of the Yakataga Formation to estimate a minimum shortening rate of $-5-6 \mathrm{~mm} / \mathrm{yr}(-0.2-0.24 \mathrm{in} / \mathrm{yr})$ for the Sullivan thrust sheet distributed between the Miller Creek fault $(1.3 \mathrm{~mm} / \mathrm{yr}[0.05 \mathrm{in} / \mathrm{yr}])$ and the Sullivan fault ( $4.5 \mathrm{~mm} / \mathrm{yr}$ [0.18 in/yr]). Furthermore, Meigs and others (2008) determined that the shortening rate on the offshore thrust sheet had increased from -1 to $-6 \mathrm{~mm} / \mathrm{yr}(-0.04$ to $-0.24 \mathrm{in} / \mathrm{yr})$ between 1.8 and $0.25 \mathrm{Ma}$ and was distributed across two main folds (A1 and A2 in Meigs and others, 2008) with minimum shortening rates of 5.6 and $0.9 \mathrm{~mm} / \mathrm{yr}(0.22$ and 0.04 in/yr). These folds represent the eastern extension of the Pamplona fault zone, which also accommodates $-6 \mathrm{~mm} / \mathrm{yr}(0.2 \mathrm{in} / \mathrm{yr}$ ) of shortening (Worthington and others, 2010; Chapman and others, 2008). Broadly binned slip rates of between -1 and $5 \mathrm{~mm} / \mathrm{yr}(-0.04$ and $0.2 \mathrm{in} / \mathrm{yr}$ ) have been assigned to individual faults of the Chugach-St. Elias fold-and-thrust belt in the Quaternary fault and fold database for Alaska (Koehler and others, 2012a) consistent with the observations in Meigs and others (2008).

Geodetic studies suggest that the shortening rate across the St. Elias orogen is $-35 \mathrm{~mm} / \mathrm{yr}(-1.4 \mathrm{in} / \mathrm{yr})$ (Sauber and others, 1997; Fletcher and Freymueller, 2003; Elliott and others, 2010), considerably more than the geologically determined rates. For example, geodetically measures shortening rates across the Malaspina and the Yakataga-Chaix Hills region are on the order of $10.5 \pm 3 \mathrm{~mm} / \mathrm{yr}$ and $22.0 \pm 1.4 \mathrm{~mm} /$ yr, respectively (Elliott and others, 2013). This implies that additional deformation is accommodated by some combination of detachment below the orogen, distributed deformation within the orogen, and/or farfield deformation north of the orogen. From a seismic hazards perspective, the discrepancy in geologic and geodetic deformation rates suggests that additional seismic sources might exist within the Chugach-St. Elias Mountains and that additional studies are required to better constrain the Holocene slip rates associated with individual known structures.

Paleoseismic trenching studies across scarps in the hanging wall above the Ragged Mountain fault at Kushtaka Mountain and Martin Lake indicate formation of sackung and uphill-facing scarps by either creep or oblique normal faulting along flexural slip bedding plane faults (McCalpin and others, 2011). At Kushtaka Mountain, McCalpin and others (2011) infer the occurrence of three creep events accompanied by episodic deposition and soil formation, including two events that predate $10.2 \mathrm{cal} \mathrm{ka}$ and a third event that occurred after 9,920-10,200 cal yrs B.P. but before 6,670-6,800 cal ka. Trenches near Martin Lake indicate the occurrence of four late Quaternary faulting events (McCalpin and others, 2011).

Two great $\left(M_{W} 8.1\right.$ and $\left.M_{W} 8.2\right)$ and one large earthquake $\left(M_{s} 7.4\right)$ were generated along the eastern side of the system in 1899, causing coastal uplift (14.4 $\mathrm{m}$ [47.2 ft] maximum) over a $1,500 \mathrm{~km} 2$ area (Tarr and others, 1912). Plafker and Thatcher (2008) evaluated the distribution of raised shoreline platforms and fit the data by allowing $-10-20 \mathrm{~m}(-33-66 \mathrm{ft})$ dip-slip displacement on three dextral oblique thrust faults that dip $-30^{\circ}$ northeast or north including the Yakutat, Bancas Point/Esker Creek, and Boundary faults (fig. 4). Slip also occurred along the Otmeloi fault. Plafker and Thatcher (2008) suggest that -1 $\mathrm{m}(-3.3 \mathrm{ft})$ of uplift at Yakataga indicates that faulting extended to the west into the Chugach-St. Elias fold-and-thrust belt (foothill fold-and-thrust zone in Plafker and Thatcher, 2008). The most recent paleoearthquake (pre-1899) in the Yakutat area occurred at least $380 \pm 70$ years ago, (Plafker and Thatcher, 2008). Because this area has not ruptured with a great earthquake since 1899 and is accumulating convergent strain at $-48 \mathrm{~mm} / \mathrm{yr}(-1.9 \mathrm{in} / \mathrm{yr})$, it has been identified as a possible "seismic gap" with a high likelihood of producing another large earthquake and possibly an accompanying tsunami.

The transition fault is oriented west-northwest along the structural boundary between the Yakutat terrane and the Pacific plate (fig. 3). At its southeastern end the Transition fault projects toward the Fairweather-Queen Charlotte fault and extends to within about $100 \mathrm{~km}(62 \mathrm{mi})$ of Sitka. The 
Transition fault has not produced a significant earthquake in historic time except for the 1973 M 6.7 event along the southeastern end of the fault (Perez and Jacob, 1980). Seismic images indicate that the fault changes from a single strike-slip boundary in the east to three strands that step seaward toward a junction with the Alaska-Aleutian trench, becoming increasingly more transpressional to the west (Gulick and others, 2013). The fault is associated with a steep dip, clear scarps on the sea floor that cut small submarine fans at the base of the continental slope, and displaced glacial strata consistent with Quaternary activity (Gulick and others, 2013, 2007; Christeson and others, 2010). Because of the challenges inherent to offshore paleoseismology, timing, recurrence, and slip rate data have not yet been developed and the seismic potential of the Transition fault has not been characterized.

South of the Transition fault, the north-southtrending Gulf of Alaska fault zone produced a series of strong earthquakes offshore including a M 7.7 in 1987 and a M 7.8 in 1988 (fig. 1B). These earthquakes caused significant ground motions that were felt along the entire southeastern and southern Alaska coast.

\section{BENIOFF ZONE SEISMIC SOURCE}

A well-defined Benioff zone characterized by concentrated seismicity along the subduction interface between the Pacific and North American plates extends from the Aleutian Arc in southwestern Alaska to the Alaska Peninsula and Cook Inlet in southcentral Alaska, and terminates beneath the northern foothills of the Alaska Range in interior Alaska (fig. 1A). The geometry of the Alaska-Aleutian Benioff zone changes along strike. A steeply dipping Benioff zone is observed to the west in the Aleutians, while gently dipping subduction is observed to the east in central Alaska. Beneath Denali (formerly named Mt. McKinley), the Benioff zone shows a clear change in strike, perhaps indicating segmentation of the subducting plate (Ratchkovski and Hansen, 2002).
The Benioff zone is highly active and represents a regionally extensive source of potentially hazardous earthquakes up to $M$ 7.9. The deepest of these events (down to $-260 \mathrm{~km}$ [160 mi]) occur in the central Aleutian arc. In south-central Alaska the seismicity abates at a depth of approximately $225 \mathrm{~km}$ (140 mi), reflecting the down-dip extent of the Pacific plate and/or a transition to plastic deformation. Abrupt termination of intermediate- and deep-focus events near $148^{\circ} \mathrm{W}$ longitude (Davies, 1975) leaves the eastern section of the Benioff zone beneath southcentral Alaska open to interpretation. The Benioff zone produces thousands of earthquakes each year, most of which are too deep and too small to be felt. The 1999 M 7.0 and 2001 M 6.9 Kodiak Island earthquakes occurred along the Benioff zone and caused considerable damage and disruptions to the city of Kodiak and other communities on the island. Anchorage experiences a few felt earthquakes originating from the Benioff zone beneath the city each year, with notable events occurring in 2014 (M 6.3), 1999 (M 5.2), and 1991 (M 6.3). The 2015 (M 6.4) Iliamna and (M 7.1) Iniskin earthquakes also occurred in the subducting Pacific plate and were widely felt across south-central Alaska, the Kenai Peninsula, and as far north as Fairbanks. The Iniskin event was one of four intermediate-depth earthquakes of $M>6$ in the Cook Inlet region since July 2014 and nucleated at a depth of $125 \mathrm{~km}$ (78 mi) (West and others, 2016). In the western Aleutians, the 2014 M 7.9 Rat Islands earthquake nucleated at a depth of $118 \mathrm{~km}(73 \mathrm{mi})$ beneath Amchitka and represents the largest intra-slab earthquake ever recorded in Alaska (AEC, 2016).

Although earthquakes along the Benioff zone do not pose a surface fault rupture hazard, strong ground motions generated by these relatively deep events are of concern for seismic engineering. Based on the site-to-source distance of these earthquakes to infrastructure projects, seismic source investigations often conclude that Benioff zone earthquakes are the dominant source to consider in seismic engineering design (Fugro Consultants, 2011) 


\section{INTRAPLATE SEISMIC SOURCE REGIONS South-central Alaska source region}

The south-central subregion is between the Aleutian subduction zone on the south and the Alaska Range on the north, and includes the western Alaska Range, Cook Inlet, Susitna basin, Talkeetna Mountains, Kenai Peninsula, and Copper River basin (figs. 1 and 5). The recorded history of seismicity in this source region indicates a bimodal distribution of events with 27 percent of located earthquakes originating in the shallow crust and 73 percent as intermediate and deep interplate events extending far inland along the shallowly dipping AlaskaAleutian Benioff zone described above. Historical data indicate that a strong earthquake has occurred in south-central Alaska once every few years, with nearly $1,600 \mathrm{M} \geq 4$ earthquakes and more than ten major earthquakes ( $M \geq 7)$ (AEC, 2016).

The main sources for shallow crustal earthquakes in the south-central Alaska source region include the Castle Mountain fault, fault-cored folds in Cook Inlet, and the Pass Creek fault (fig. 5).

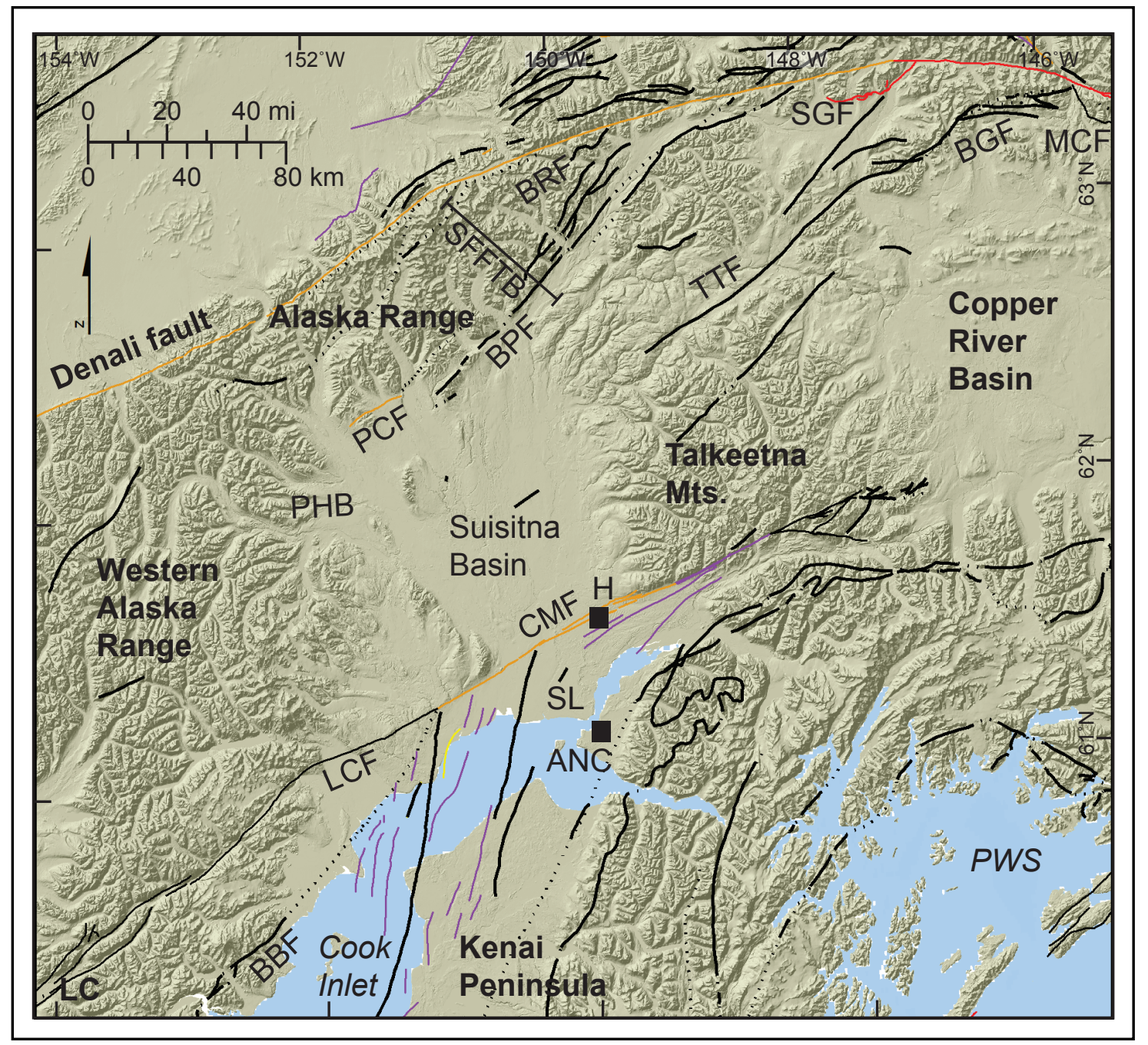

Figure 5. Map of the south-central Alaska source region, showing known active and potentially active Quaternary faults. Fault colors indicate relative age from Koehler (2013); see figure 2 for defini-tions. ANC = Anchorage, $\mathrm{BGF}=$ Broxson Gulch fault, BPF = Broad Pass fault, BRF = Bull River fault, CMF = Castle Mountain fault, $\mathrm{H}=$ Houston, $\mathrm{LC}=$ Lake Clark, $\mathrm{LCF}=$ Lake Clark fault, $\mathrm{BBF}=$ Buin Bay fault, $\mathrm{PHB}=$ Peters Hills Basin, $\mathrm{MCF}=$ McCallum Creek fault, PCF = Pass Creek fault, PWS = Prince William Sound, SGF = Susitna Glacier fault, SL = Susitna Lowland, TTF = Talkeetna thrust fault, SFFTB = Southern Foothills fold and thrust belt. 
Additional northeast-trending faults mapped in bedrock, including Broad Pass fault, Broxson Gulch fault, and Susitna Glacier fault, project toward the Denali fault and are favorably oriented to be reactivated in the modern stress field. Quaternary motion along these faults has not been documented except for the Susitna Glacier fault, which ruptured in the 2002 Denali fault earthquake and is described separately in the interior Alaska source region below. The Lake Clark and Bruin Bay faults in the southwestern part of the subregion are additional potentially active seismic sources, although recent activity has not previously been documented. Thick glacial deposits flanking the southern side of the Alaska Range, particularly in the Broad Pass, Copper River basin, and Susitna basin areas, may bury and obscure evidence of additional active faults. Earthquakes along the Benioff zone associated with the Aleutian subduction zone deep beneath the south-central source region do not represent a surface fault rupture hazard but will generate future strong ground motion hazards.

The Castle Mountain fault extends between the Talkeetna Mountains and the Susitna River and has long been considered an active fault in neotectonic and seismic hazard studies. In the Susitna Lowland the fault is expressed at the surface by a distinct south-facing scarp and vegetation lineament (Detterman and others, 1974). The sense of motion along the fault has been described as reverse, normal, and right-lateral strike-slip in various studies (Grantz, 1966; Barnes, 1962; Bruhn, 1979; Haeussler and others, 2002). Late Tertiary dip-slip reverse movement has resulted in at least $0.5 \mathrm{~km}(0.3 \mathrm{mi})$ of north-side-up displacement and the fault is associated with a 4-km-wide ( 2.5 -mi-wide) anticline (Haeussler and others, 2000). Along the Talkeetna Mountains, post-Paleocene lateral slip is estimated to be $-14 \mathrm{~km}$ ( -8.7 mi) (Fuchs, 1980; Kelley, 1963). Two historic earthquakes have occurred along the Castle Mountain fault including the $1984 \mathrm{Mb} 5.7$ (Lahr and others, 1985, 1986) and 1996 M 4.6 earthquakes near Sutton, Alaska. These events were associated with right-lateral slip in the shallow crust but did not produce surface rupture.

Previous paleoseismic investigations along the Castle Mountain fault have reported conflicting results with respect to the style and rate of Quaternary deformation. For example, Detterman and others (1974) dated a buried soil exposed in a trench excavated across a 2.1-m-high (6.9-ft-high) scarp east of the Little Susitna River and implied an 1,860 \pm 250 yrs B.P. age for the most recent event. At this locality, the fault dips $75^{\circ}$ north. Detterman and others (1974) also suggested possible right-lateral displacements of 3.6 to $7 \mathrm{~m}$ (12 to $23 \mathrm{ft}$ ). Haeussler and others (2002) conducted trenching studies and documented thrust motion along the fault and the occurrence of four late Holocene earthquakes in the last 2,700 years with a recurrence interval of -700 years. The date of the fourth paleoearthquake in the Haeussler and others (2002) study is similar to the date of the most recent event documented by Detterman and others (1974). A more recent trenching study by Koehler and others $(2014 ; 2016)$ suggested the occurrence of at least two earthquakes that broke post-late Elmendorf (14-15 ka) glacial deposits. Radiocarbon analyses from sediments that bury the second to last (penultimate) surface rupture indicate that the penultimate earthquake occurred prior to -12 cal yrs B.P. (Koehler and others, 2016). The age of the last surface rupture (most recent event) was unconstrained. Stratigraphic relations exposed in the trenches show drag folding, vertical offsets, and thickness changes across faults that support both vertical and lateral deformation. However, stratigraphic packages were generally consistent across the fault zone, from which Koehler and others $(2014 ; 2016)$ suggested that the lateral component of slip is small. The relatively fewer number of earthquakes during the Holocene documented by Koehler and others (2014; 2016) as compared to the paleoseismic history determined by Haeussler and others (2002) suggests that the recurrence interval might be longer than previously thought. Additional trenching studies 
along the Castle Mountain fault would help resolve this discrepancy in the number of Holocene events.

A late Pleistocene-Holocene right-lateral slip rate of $2-3 \mathrm{~mm} / \mathrm{yr}(0.08-0.12 \mathrm{in} / \mathrm{yr})$ for the Castle Mountain fault was estimated by Willis and others (2007) based on a lateral offset of $36 \mathrm{~m}(118 \mathrm{ft})$ measured on an interpreted subtle post-glacial outwash channel margin observed during aerial and ground reconnaissance. Koehler and others (2012b) re-evaluated this site and interpreted lidar imagery, generated 17 scarp profiles, and conducted surficial geologic mapping along the Castle Mountain fault between Houston and the Susitna River. Their observations indicate that the fault is confined to a narrow zone in some areas, but is more commonly associated with a wide zone of deformation consisting of left-stepping, en echelon surface scarps oblique to the trace of the fault (figs. 6A and 6B) and left-stepping grabens up to $400 \mathrm{~m}(1,312 \mathrm{ft})$ north of the scarp. Multiple piercing points across the fault, including numerous abandoned channels, stabilized sand dunes, and terrace margins, were found to be vertically offset between 1 and $5 \mathrm{~m}$ (3.3 and 16.4 ft) (figs. 6C and 6D). Koehler and others (2012b) did not observe lateral offsets of the -13 ka Elmendorf moraine, associated outwash channels, and other landforms crossing the fault in the field; however, noted that the curvilinear morphology of displaced landforms may have precluded the observation of small lateral offsets. Larger-scale geomorphic features indicative of strike-slip deformation along the fault were also noted to be absent by Koehler and others (2012b) including pressure ridges, sag ponds, and opposite-facing scarps, among others. Based on these observations, Koehler and others (2012b) inferred that the scarp morphology is more consistent with a high-angle oblique reverse fault and that grabens north of the fault were formed by folding and extension in the hanging wall block. If correct, these observations conflict with the lateral sense of motion and slip rate of $3 \mathrm{~mm} / \mathrm{yr}(0.1 \mathrm{in} / \mathrm{yr})$ presently used in probabilistic seismic hazard maps for Alaska (Wesson and others, 2007). A vertical displacement rate of $-0.5 \mathrm{~mm} / \mathrm{yr}$
$(-0.02 \mathrm{in} / \mathrm{yr})$ is consistent with the Holocene offsets across the Susitna Lowland (Koehler and others, 2012b). A small component of lateral slip is permissible, as evidenced by the en echelon scarps; however, this component is not constrained. GPS-measured subtle westward motion of the forearc region around the Kenai Peninsula (Snay and others, 2013; Fletcher, 2002) might be responsible for the oblique component of slip on the Castle Mountain fault.

The Lake Clark fault occupies a major linear valley that cuts across the western Alaska Range from Lake Clark to the western end of the Castle Mountain fault (figs. 5 and 7). Due to its position along strike of, and extending from, the Castle Mountain fault, the Lake Clark fault is often considered a potentially active fault in seismic hazard assessments. Previous bedrock mapping investigations along the Lake Clark fault have documented Tertiary vertical, up-to-the-northwest displacements of 500-1,000 m (1,640-3,280 ft) and dextral displacements of $5 \mathrm{~km}(3.1 \mathrm{mi})$ (Detterman and others, 1976; Plafker and others, 1975). The fault is associated with a 30-50-m-wide (98-164-ft-wide) shear zone that juxtaposes Tertiary plutonic and upturned sedimentary rocks (Detterman and others, 1976). A post-late Eocene right-lateral displacement of $26 \mathrm{~km}$ (16.2 mi) was documented by Haeussler and Saltus (2005) based on aeromagnetic data that showed offset granitic plutons along the fault. Schmoll and Yehle (1987) suggested Quaternary displacement of early Naptowne age glacial moraines along the fault at the northeastern side of Lone Ridge west of Tyonek, but did not discuss definitive evidence. Koehler and Reger (2011) performed helicopter and ground mapping along the fault in the vicinity of Lone Ridge and determined that there was no conclusive evidence for offset of MIS 2 and MIS 4 glacial deposits northeast and southwest of the ridge. Based on possible scarps in MIS 6 glacial deposits and stream profiles across the fault that show subtle convex-up profiles, Koehler and Reger (2011) suggested the possibility of northside-up slip along the fault in the last $-130 \mathrm{ka}$. These 


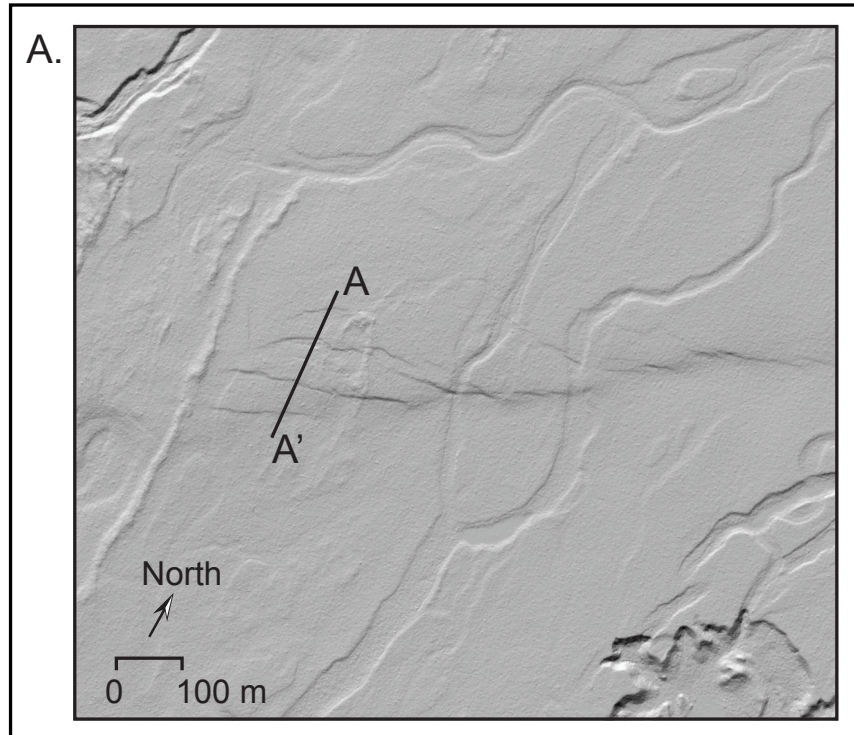

B.
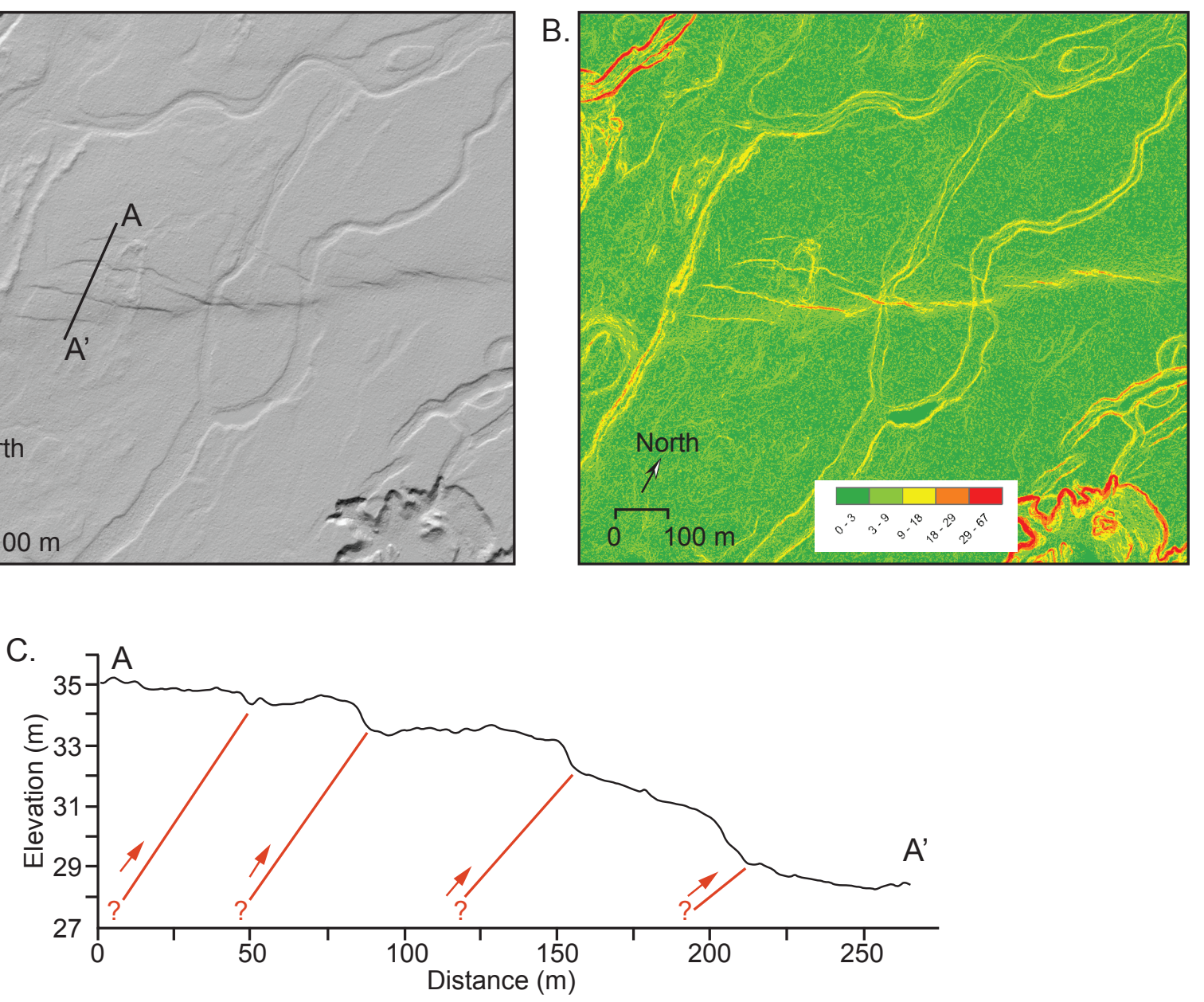

D.

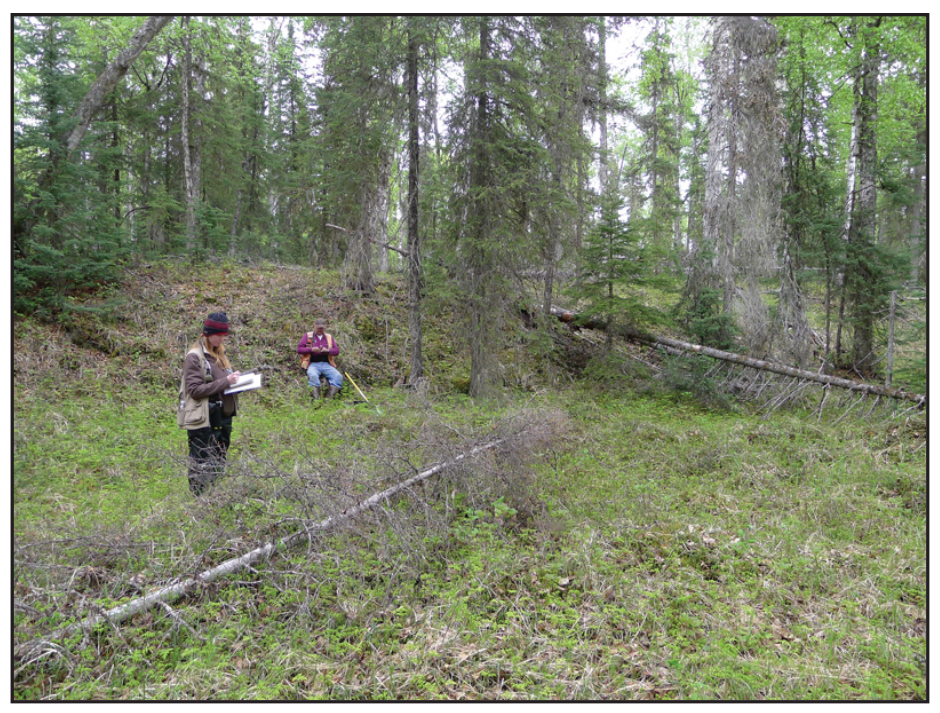

Figure 6. A. Lidar-derived 1-m hillshade map, and B. lidar-derived slope map of the Castle Mountain fault, showing left-stepping en echelon scarps and general lack of lateral offset of abandoned latest Pleistocene stream channels. Both A and B taken from Koehler and others (2017). C. Topographic profile A-A', showing vertical character of scarps. Faults are schematic. D. Photograph of vertical scarp. Geologists for scale. 


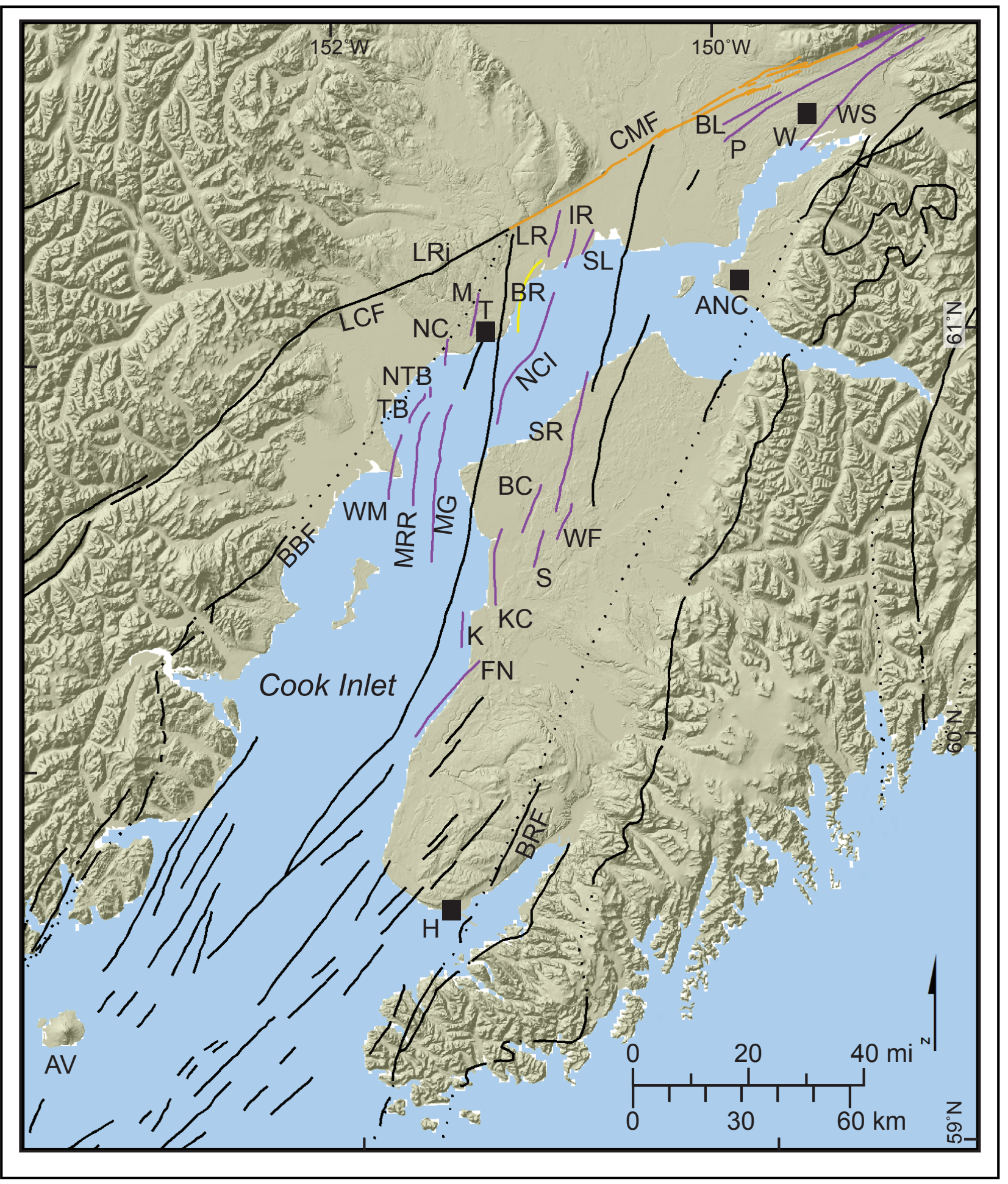

Figure 7. Map of the Cook Inlet area, showing active and potentially active faults. Fault colors indicate relative age of activity from Koehler (2013); see figure 2 for definitions. AV = Augustine volcano, BBF = Bruin Bay fault, BC = Beaver Creek an $\neg$ ticline, BL = Big Lake North anticline, BR = Beluga River anticline, CMF = Castle Mountain fault, FN = Falls Creek-Ninilchik anticlines, $\mathrm{H}=\mathrm{Homer}$, $\mathrm{IR}=$ Ivan River anticline, $\mathrm{K}=$ Kasilof anti-cline, $\mathrm{KC}=$ Kenai-Cannery Loop anticline, $\mathrm{LCF}=$ Lake Clark fault, $\mathrm{LR}=$ Lewis River anticline, $\mathrm{LRi}=$ Lone Ridge, $\mathrm{M}=$ Moquawkie anticline, $\mathrm{MG}=$ Middle Ground Shoal anticline, MRR = McAr-thur River-Redoubt Shoal anticline, $\mathrm{NC}=$ Nicolai Creek anticline, $\mathrm{NCl}=$ North Cook Inlet-SRS anticline, NTB = North Trading Bay anticline, $\mathrm{P}=$ Pittman anticline, $\mathrm{S}=$ Sterling anticline, $\mathrm{SL}=$ Stump Lake anticline, $\mathrm{SR}=$ Swanson River anticline, $\mathrm{T}=$ Tyonek, $\mathrm{TB}=$ Trading Bay anticline, $\mathrm{W}=\mathrm{Wasilla}$, $\mathrm{WF}=$ West Fork anticline, $\mathrm{WM}=$ West McArthur River anticline, WS = Wasilla St. No. 1-Needham anticline. 
reconnaissance observations indicate that the Lake Clark fault could be active, albeit with a very low slip rate, but it remains poorly characterized.

Seismic sources within the Cook Inlet forearc basin are associated with the Cook Inlet fold belt and include numerous north-northeast-trending, discontinuous, asymmetric folds that are cored by blind reverse faults (fig. 7). The location and extent of these structures has been interpreted primarily from proprietary seismic reflection data, structure contour maps, cross sections, and aeromagnetic data (Haeussler and Saltus, 2011, Haeussler and others, 2000; Magoon and others, 1976; fig. 9 in Magoon, 1994; Boss and others, 1976; Kirschner and Lyon, 1973). Numerous structures that have displaced Tertiary sediments are present in the southern part of the inlet in the vicinity of Homer and Augustine Volcano (Haeussler and Saltus, 2011); however, their Quaternary activity and seismic potential is poorly constrained. In northern Cook Inlet, active anticlines include the Stump Lake, Ivan River, Lewis River, Moquawkie, Nicolai Creek, Beluga River, Trading Bay, North Trading Bay, West McArthur River, McArthur River-Redoubt Shoal, Middle Ground Shoal, North Cook Inlet-SRS, Swanson River, West Fork, Beaver Creek, Sterling, Kenai-Cannery Loop, Kasilof, and Falls Creek-Ninilchik anticlines (fig. 7). Several other lesser-studied and poorly defined folds in the northern part of the inlet are shown in Haeussler and Saltus (2011). In the vicinity of Wasilla, several more northeasterly oriented active fault-cored folds extend subparallel to the Castle Mountain fault, including the Wasilla State No. 1-Needham, Pittman, and Big Lake North anticlines. Quaternary activity is inferred for many of the anticlines in the northern part of the basin based on deformed PlioPleistocene sediments offshore and deflection of rivers around topographic highs on land (Haeussler and others, 2000; Kelley, 1961). These structures range in length from 3 to $85 \mathrm{~km}(2-53 \mathrm{mi})$, and are optimally oriented in the modern stress field to generate moderate to large (M 6-7) earthquakes (Haeussler and others, 2000; Haeussler, 2008; Bruhn and Haeussler, 2006). A large earthquake (M 6.9) on April 26, 1933 (Doser and Brown, 2001) might have occurred along the North Cook Inlet anticline (Haeussler and others, 2000). Due to the location of the structures on the sea floor and the poor resolution of Holocene sediments in seismic reflection and well data, earthquake timing and recurrence data do not exist for the Cook Inlet fold belt and slip rate data are only available for several structures. Given the evidence for Quaternary motion and diffuse low-level seismicity, Koehler and others (2012a) assigned a poorly constrained slip rate of $<0.2 \mathrm{~mm} / \mathrm{yr}(<0.01 \mathrm{in} / \mathrm{yr})$ for the majority of the Cook Inlet structures. Based on interpretation of balanced cross sections that show deformation and growth strata that extend above the base of the Plio-Pleistocene Sterling Formation, Haeussler and others (2000) calculated poorly constrained slip rates for the Middle Ground Shoal and the North Cook Inlet structure of $-0.3 \mathrm{~mm} / \mathrm{yr}(-0.01 \mathrm{in} / \mathrm{yr})$ and -3 $\mathrm{mm} / \mathrm{yr}(-0.1 \mathrm{in} / \mathrm{yr})$, respectively, and used empirical relations to estimate recurrence intervals of several hundred to several thousand years.

The Bruin Bay fault system is a potentially active seismic source, extending northeast $-450 \mathrm{~km}(-280$ mi) from the upper Alaska Peninsula to the upper Cook Inlet forearc basin (Detterman and Hartsock, 1966) (fig. 7). The fault system is a series of steeply northwest-dipping reverse faults that marks the northwestern margin of Cook Inlet and separates the crystalline batholith and volcanic rocks of the western Alaska Range on the northwest from Cenozoic basin fill sediments to the southeast. Vertical stratigraphic displacements are as much as 3,000 $\mathrm{m}(9,840 \mathrm{ft})$ near the Iniskin Peninsula (Detterman and Hartsock, 1966), but decrease to the north near Tyonek, where Tertiary deposits are only offset a few hundred meters (Detterman and others, 1975). The system is associated with numerous steeply dipping faults in the hanging wall and a several-hundred-meter-wide shear zone. Geologic mapping and kinematic studies in the central part of the system indicate that 
the system has evolved through multiple phases of deformation including periods of reverse, left-, and right-lateral slip (Betka and Gillis, 2014; Detterman and Hartsock, 1966; Detterman and Reed, 1980); however, it is considered to have been inactive since late Tertiary time (Detterman and others, 1975). Although Holocene fault scarps have not been identified along the fault, seismic reflection data suggests that the northern part of the fault may be associated with Quaternary deformation (Haeussler and others, 2000). The geographic position of the system as a major structural element of the actively deforming Cook Inlet forearc basin parallel to the active Cook Inlet fold belt, as well as diffuse shallow seismicity and possible intersection with the active Castle Mountain fault, suggest the potential for fault reactivation in the modern stress field.

Along the southern side of the Alaska Range a northeast-oriented structural grain and elevated topography generated by transpressive deformation along the Denali fault has resulted in the development of the informally named southern Foothills fold-and-thrust belt, a system of south-directed thrust faults, blind master thrusts, and fault-cored folds (Haeussler, 2008). This system of faults includes the Broad Pass fault zone, Bull River fault, and the Pass Creek fault (fig. 5). Bemis and others (2015) evaluated kinematic constraints on crustal motions in the region and showed that strain must be accommodated by northeast-striking thrust faults as well as partitioned to other structures north of the range. The causative mechanisms for this deformation are summarized in Haeussler (2008) and expanded upon in Bemis and others (2015), who inferred that slip partitioning is related to a combination of effects including counterclockwise rotation and northwest migration of the southern Alaska block, as well as the westward decrease in Denali fault slip rate. The majority of the northeast-striking structures (such as Broad Pass and Broxson Gulch faults, among others) are only recognized in bedrock and show no evidence of displacing Quaternary sediments; however, due to latest Wisconsin glacial advances, the Quaternary geologic record is short and may not record the most recent events. Blind active traces are likely buried across the southern side of the Alaska Range and may be capable of generating large earthquakes. Despite the difficulty in recognizing active structures in this area, active deformation has been recognized along the Pass Creek and Susitna Glacier faults.

The Pass Creek fault extends about 24 km (15 mi) between the Kahiltna and Yentna rivers in the vicinity of Fairview Mountain (figs. 5 and 8A) and was originally described as a normal fault based on the juxtaposition of Tertiary rocks against Cretaceous rocks (Reed and Nelson, 1980). Haeussler (2008) described the Pass Creek fault as a normal fault adjacent to Peters Hills basin, a broad synform. Based on fluvial geomorphology across the scarp, Haeussler (2008) inferred that Peters Hills basin formed in the hanging wall of a southeastward-directed thrust fault. This observation is consistent with crustal seismicity near Pass Creek fault, which is associated with earthquakes up to $M$ 5.4, showing thrust motion on northeast-striking and northwest-dipping fault planes (Doser, 2004). In the Chelatna Lake basin, the fault is expressed as a distinct north-facing 1.5 to $4.3 \mathrm{~m} \mathrm{(5} \mathrm{to} 14 \mathrm{ft}$ ) scarp that cuts latest Wisconsin glacial moraine, outwash, and terrace deposits and has deflected Lake Creek to the east at the outlet of Chelatna Lake (figs. 8B, 9A, and 9B). Several small drainages have been blocked by the scarp, resulting in the formation of lakes north of the fault (figs. $8 \mathrm{~B}$ and 9C). At one location, the scarp displaces a moraine crest by $-3 \mathrm{~m}(-10 \mathrm{ft})$ and is characterized by an oversteepened base and two 1-m-deep (3.3-ftdeep) fissures that extend across the crest of the scarp (fig. 9D). Another north-facing scarp occurs about $3 \mathrm{~km}(1.9 \mathrm{mi})$ south of and parallel to the Pass Creek fault and is associated with a subtle scarp and distinct vegetation lineament (figs $8 \mathrm{~B}$ and 10 ). West of Lake Creek, this apparent fault scarp appears to offset a spring bog across a $\sim 0.6 \mathrm{~m}(-2 \mathrm{ft})$ scarp that is associated with ponded water on the north and 


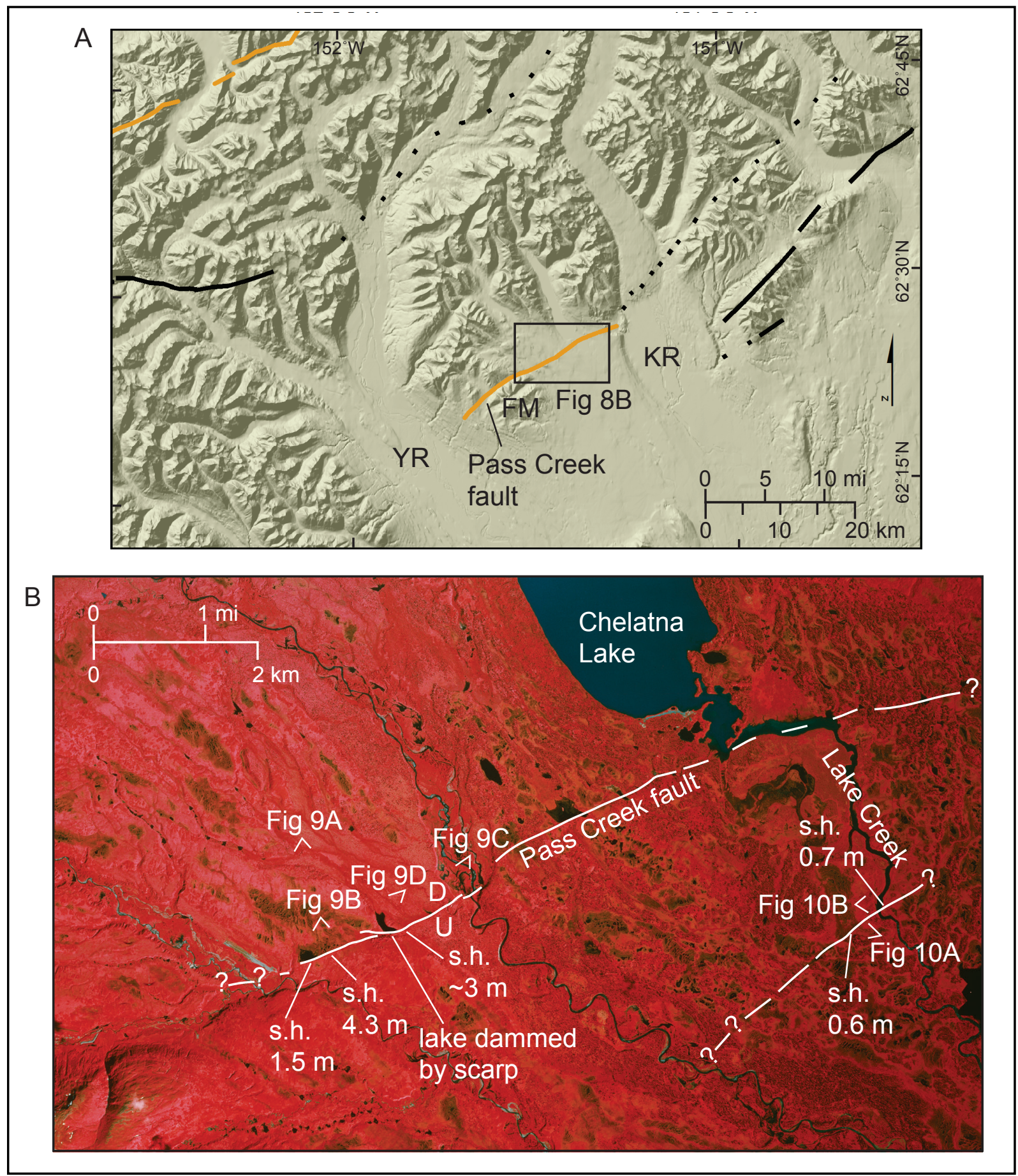

Figure 8. A. Map of the Pass Creek fault along the northern margin of the Susitna basin. Fault colors indicate relative age of activity from Koehler (2013); see figure 2 for definitions. B. Air photo interpretation of the Pass Creek fault and Pass Creek lineament near Chelatna Lake. Vertical false-color infrared aerial photograph from the Alaska High Altitude Photography (AHAP) program archived at the University of Alaska, Fairbanks. Locations of photograhs in figures 9 and 10 are indicated in $\mathrm{B}$. FM = Fairview Mountain, KR = Kahiltna River, $Y R=$ Yentna River, $D=$ downthrown side, $U=$ upthrown side, s.h. = scarp height.

abandoned depressions and low ridges on the south (fig 10A). Along the east bank of Lake Creek, the fault is associated with a possible warped Holocene fluvial terrace deposit (fig. 10B). The Quaternary geologic relations and seismicity indicate that the Pass Creek fault, and possibly the unnamed parallel 
lineament to the south are active structures capable of producing earthquakes. Deformation along these structures could be related to extension and normal faulting in the hanging wall above a blind, northdipping master thrust fault. However, the tectonic geomorphic relations described above, particularly the fissures observed in the crest of scarps, provide limited observations that could alternatively support a mechanism of deformation by north-directed backthrusting and hanging wall extension above a blind, north-dipping master thrust. Further investigation is necessary to define paleoseismic parameters associated with the Pass Creek fault and to substantiate the observations on possible style and mechanisms of deformation described above.

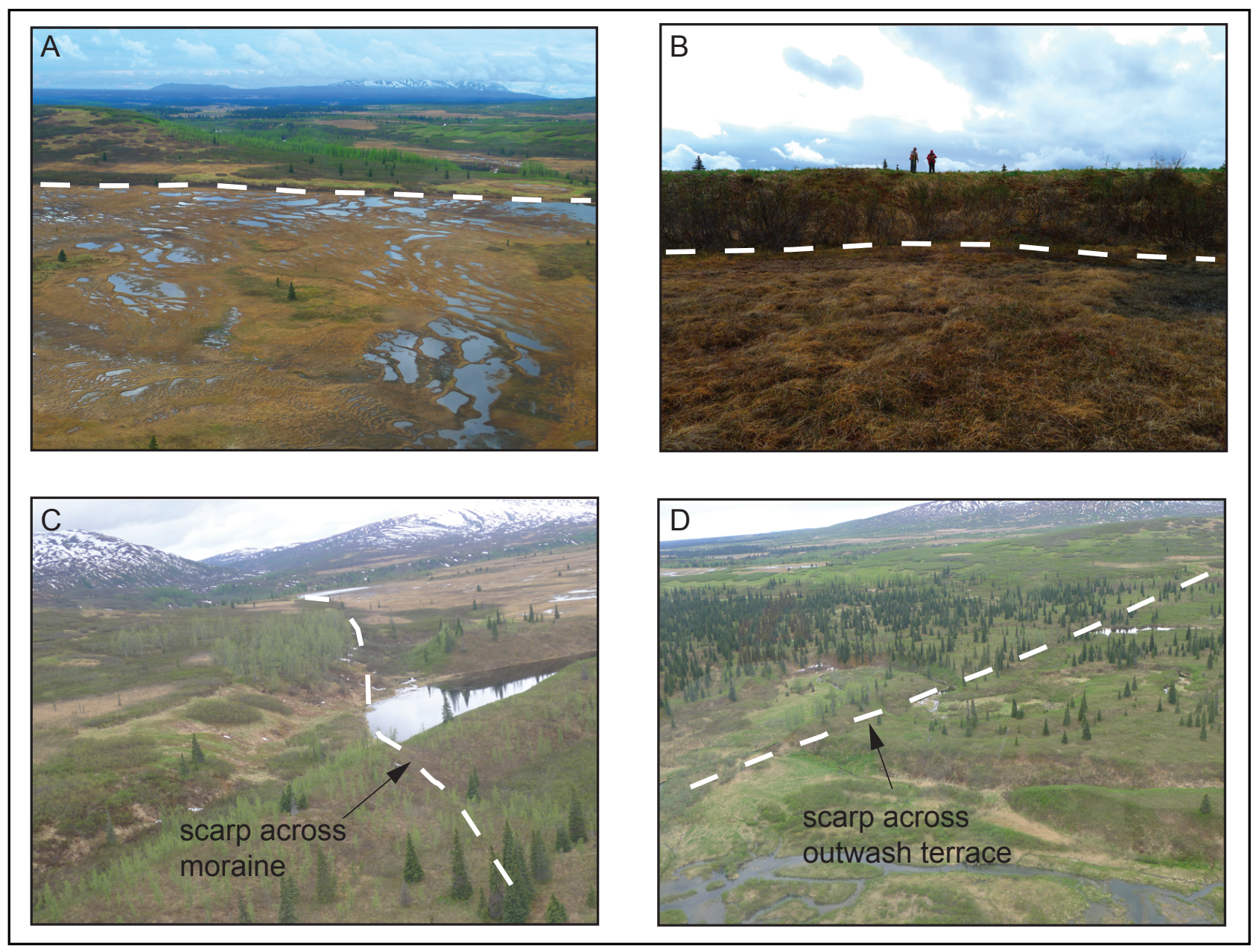

Figure 9. Photographs of tectonic scarps along the Pass Creek fault. Location of fault is at the tip of white arrows in each photo; location of photos shown on figure 8. A. View south, showing ponded water against scarp. B. Close-up view, looking south, of $4.3 \mathrm{~m}$ (14.1 $\mathrm{ft}$ ) scarp in A; geologists for scale. C. Displaced glacial moraine and lake ponded against scarp. D. Displaced glacial outwash terrace.

\section{Interior Alaska source region}

The interior Alaska source region encompasses the broad area between the Alaska Range and the Brooks Range and includes the Yukon-Tanana uplands, Yukon flats, and the Kuskokwim and Koyukuk basins (fig. 11). Interior Alaska seismicity reflects transpression and block rotation influenced by the relative motions of the Yakutat microplate, the southern Alaska block, Bering microplate, and the North American plate. Three main types of tectonic structures contribute to generating seismicity in this region: right-lateral strike-slip faults (Denali, Tintina, Kaltag), north-northeast-trending seismic zones (Minto, Fairbanks, Salcha, Dall City, Rampart), and thrust faults in the northern foothills of the Alaska 


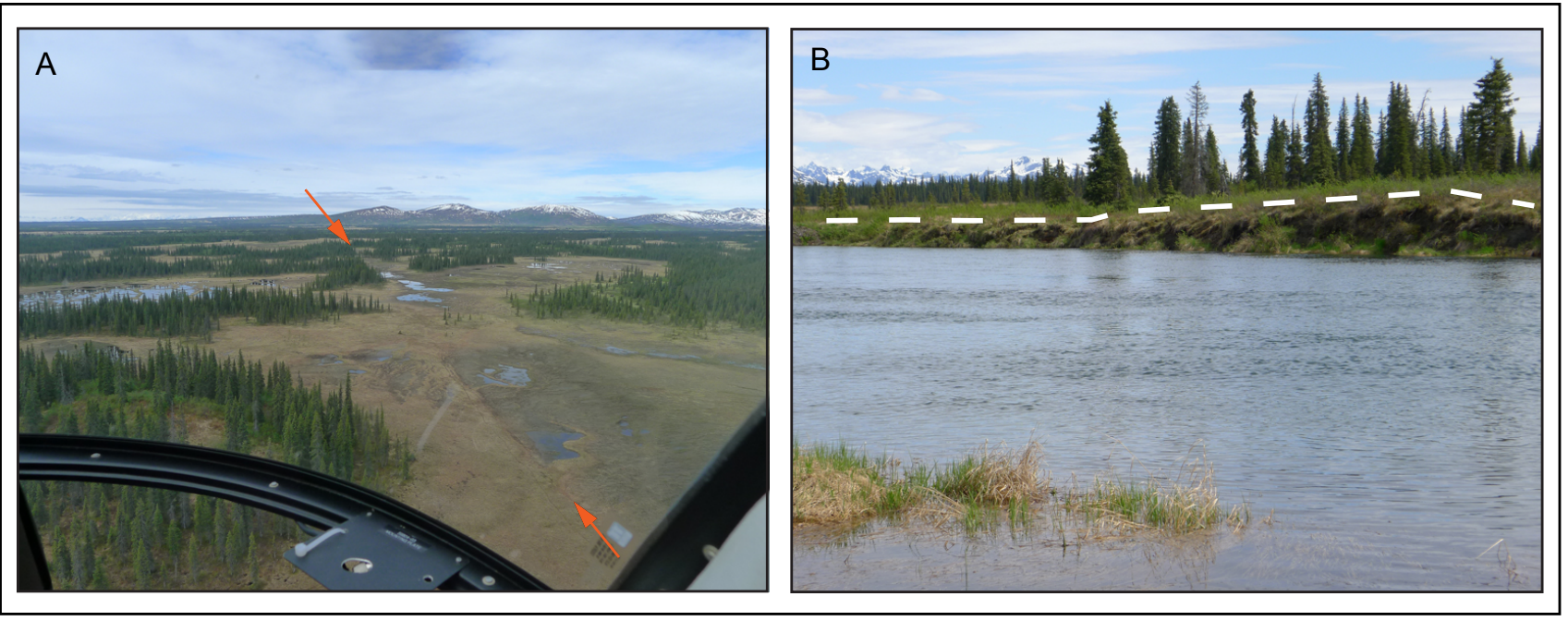

Figure 10. Photographs of unnamed lineament $\sim 3 \mathrm{~km}(\sim 1.9 \mathrm{mi})$ south of the Pass Creek fault. A. Aerial view (looking west) of lineament, showing distinct vegetation line and ponded water on the north side of an $\sim 0.6-\mathrm{m}$-high ( 2-ft-high) scarp. Possible fault extends between red arrows. B. View to northeast of possible warped Holocene fluvial terrace deposit along the east bank of Lake Creek. Terrace tread shown by dashed white line.

Range (fig. 11). Deep earthquakes beneath the interior source region are associated with the northern part of the shallowly dipping Aleutian subduction zone. Strain accumulation rates measured by GPS are poorly constrained in the Interior Alaska source region, but indicate $<1 \mathrm{~mm} / \mathrm{yr}(<0.04 \mathrm{in} / \mathrm{yr}$ ) of convergence between the Alaska Range and the Brooks Range and $-2 \mathrm{~mm} / \mathrm{yr}(-0.08 \mathrm{in} / \mathrm{yr})$ east-west across the interior Alaska seismic zones (Jeff Freymueller, oral commun., 2014). This suggests long recurrence intervals for damaging earthquakes in the interior.

The most prominent recorded earthquake in interior Alaska was the M 7.9 November 3, 2002, Denali fault earthquake (Eberhart-Phillips and others, 2003). This event was preceded by the M 6.7 Nenana Mountain earthquake on October 23 that ruptured $40 \mathrm{~km}(25 \mathrm{mi})$ of the Denali fault west of the M 7.9 event (Wright and others, 2003). Several moderate to large earthquakes that have not been linked to known active faults include the $2006 \mathrm{M}$ 5.4 Yukon Flats earthquake, followed by a M 5.1 aftershock felt as far away as Fairbanks, and the 1958 M 7.3 event near Huslia that produced extensive failures in surficial unconsolidated deposits within a northeast-striking zone (Davis, 1960).
The transpressional right-lateral Denali fault system extends over $2,000 \mathrm{~km}(-1,250 \mathrm{mi})$ in a northward convex arc from Goodnews Bay on the Bering Sea to Chatham Strait in southeastern Alaska, including $-500 \mathrm{~km}(310 \mathrm{mi})$ along the arcuate southern margin of the Alaska Range (St. Amand, 1957; Grantz, 1966; Richter and Matson, 1971; Plafker and others, 1977, 1994a) (fig. 12). The fault was the source of the $2002 \mathrm{M}_{\mathrm{W}}$ 7.9 Denali fault earthquake, one of the seven largest continental strike-slip earthquakes since 1900 (Schwartz, 2006), which ruptured 340 km (211 mi) along the Susitna Glacier thrust, Denali fault, and Totschunda fault with average displacements of 4-5 m (13-16 ft) (Eberhart-Phillips and others, 2003; Haeussler and others, 2004).

Various workers have subdivided the Denali fault system into sections that have differing names and lengths that sometimes overlap (for example, Grantz, 1966; Plafker and others, 1977). Plafker and others (1994a) named sections of the Denali fault system based on Quaternary geologic observations and apparent slip rate or differing earthquake histories including, from west to east: the Togiak-Tikchik, Holitna, Boss Creek, Farewell, Tonzona-Muldrow, west Muldrow-Alsek, central Muldrow-Alsek, 


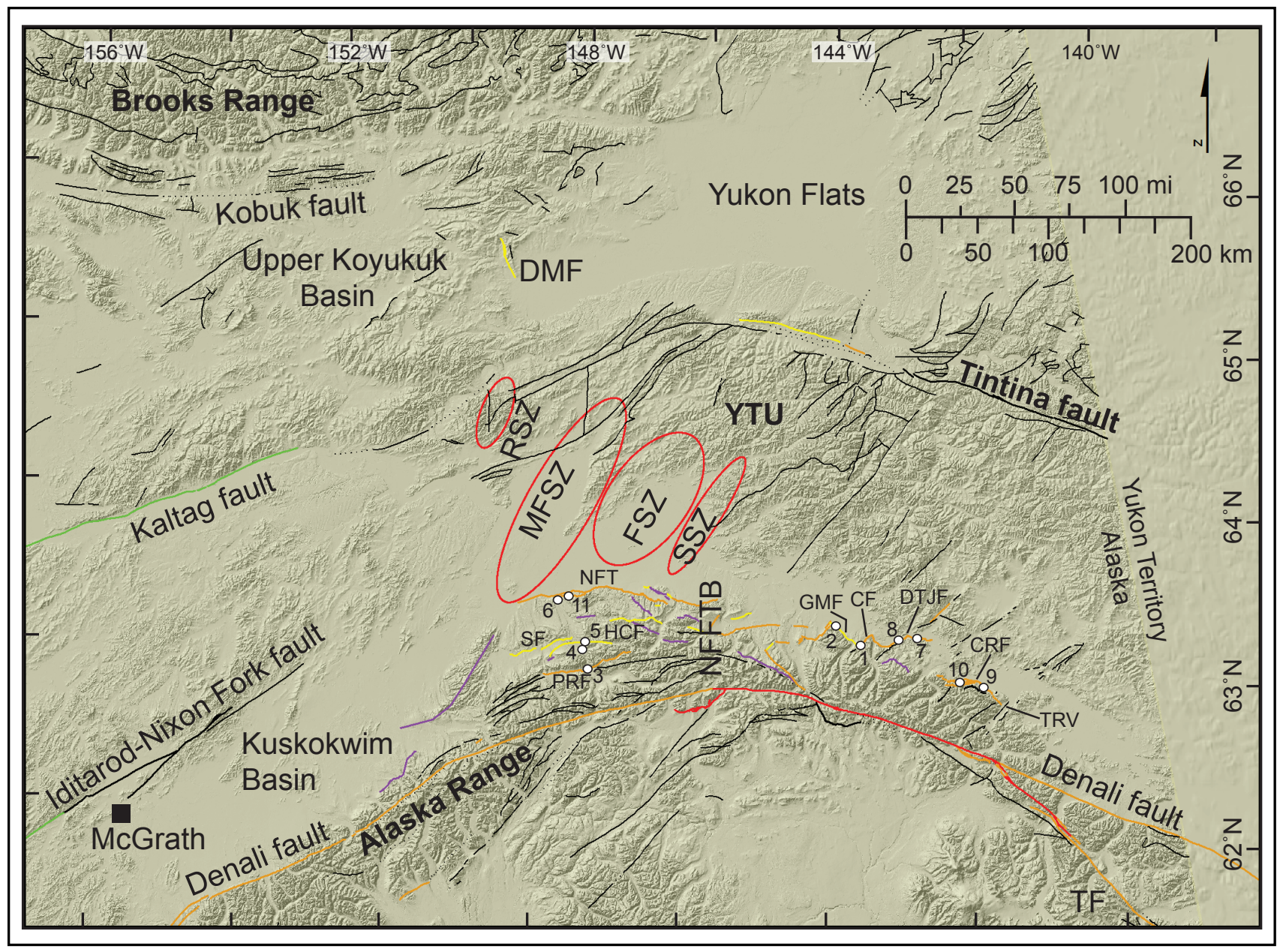

Figure 11. Map of the interior Alaska source region. DMF = Dall Mountain fault, FSZ = Fairbanks seismic zone, MFSZ = Minto Flats seismic zone, NFFTB = Northern Foothills fold-and-thrust belt, NFT = Northern Foothills Thrust, SF = Stampede fault, HCF = Healy Creek fault, PRF = Park Road fault, GMF = Granite Mountains fault, $C F=$ Canteen fault, DTJF = Dot " $T$ " Johnson fault, CRF = Cathedral Rapids fault, RSZ = Rampart seismic zone, SSZ = Salcha seismic zone, TF = Totschunda fault, YTU = Yukon-Tanana Upland, KaM = Kaiyuh MountainsKF = Kobuk fault, $\mathrm{AH}=$ Alatna Hills, $\mathrm{AM}=$ Angayucham Mountains, KRV = Kobuk River valley, ARV = Alatna River valley, $\mathrm{WHC}=\mathrm{West}$ Fork Henshaw Creek, EHC = East Fork Henshaw Creek, VCV = Victoria Creek valley, TRV = Tok River valley, MLL = Medicine Lake lineament, PCL, Preacher Creek lineament, VCF = Victoria Creek fault, HSF = Hot Springs fault, ToF = Tozitna fault, KEF = Kaltag Extension fault, $P C L=$ Preacher Creek lineament, MLL = Medicine Lake lineament, TR = Takotna River, NFR = Nixon Fork River. See Bemis and others (2012) for a more detailed collection of maps showing the distribution of individual faults in the Northern Foothills fold-and-thrust belt. Fault colors indicate relative age of activity from Koehler (2013); see figure 2 for definitions. Previous paleoseismic investigations shown by white circles include: Site 1. Carver and others (2008a); Sites 2, 4, and 5. Bemis (2010); Site 3. Koehler and others (2016); Site 6. Koehler and others (2016) and Devore and others (2012); Site 7. Carver and others (2008a; 2010); Site 8. Carver and others (2010); Site 9. Carver and others (2010); Site 10. Koehler and Woods (2013); and Site 11. Bemis (2010).

east Muldrow-Alsek, Dalton, Chilkat River, and Chatham Strait sections. To avoid confusion, these section names were retained in the Quaternary fault and fold database of Alaska (Koehler and others, 2012a; Koehler, 2013), however, after the 2002 earthquake the fault has been increasingly referred to as the western (west of Denali [formerly Mt. McKinley]), central (Denali to the Totschunda fault), and eastern (east of Totschunda fault) Denali fault (fig. 12). The Togiak-Tikchik, Holitna, and Boss Creek sections and the Chatham Strait section of Plafker and others (1994a) are described in the western Alaska-Bering Sea source region and the southeastern Alaska source region, respectively. The remaining sections 


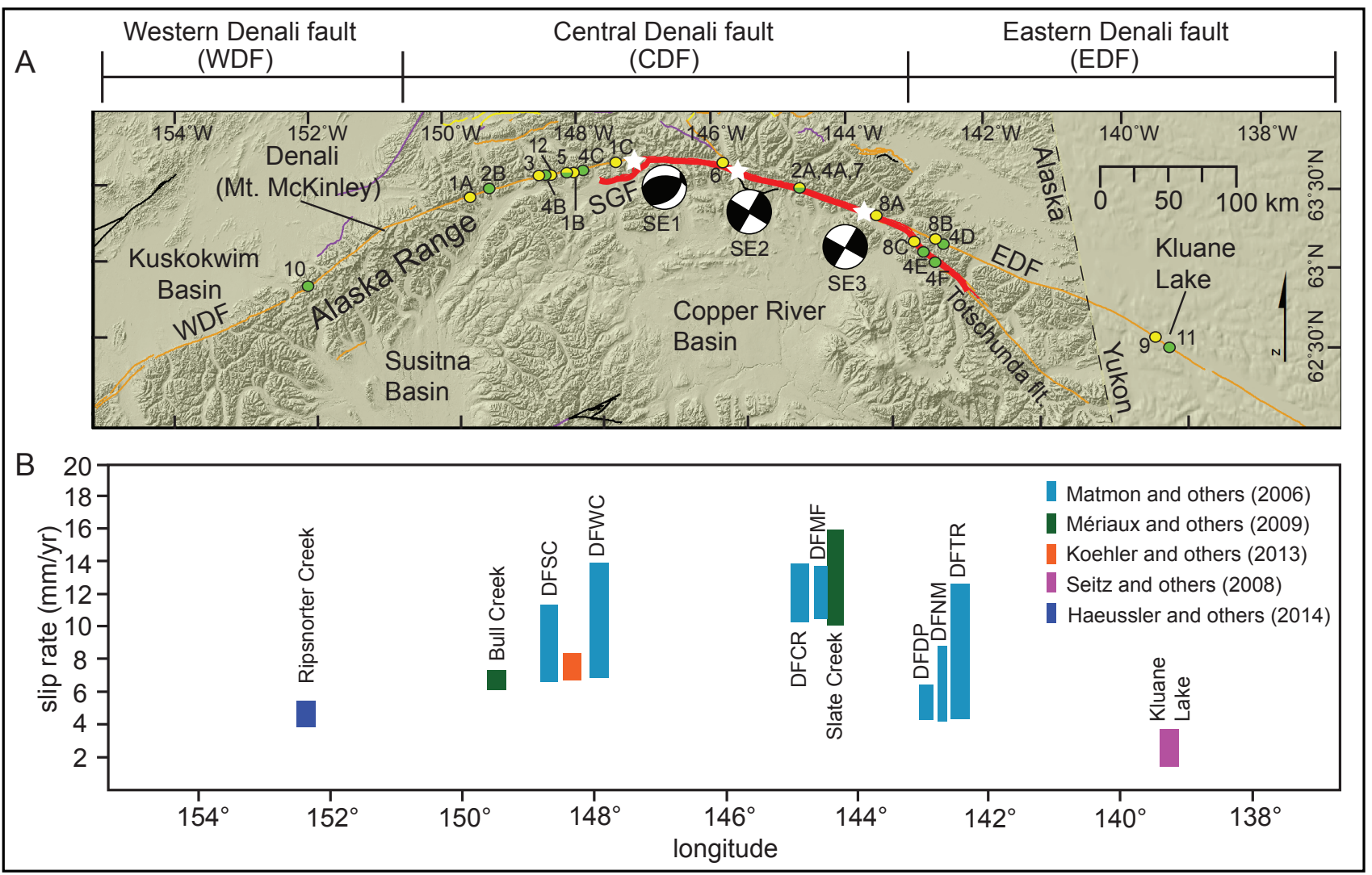

Figure 12. A. Map of the Denali fault, showing the boundaries of commonly accepted sections used in recent literature. The 2002 $M_{W} 7.9$ surface rupture is shown by a bold red line and the three subevents labeled SE1, SE2, and SE3 are shown by white stars. Fault colors indicate relative age from Koehler (2013). Locations of previous earthquake timing (yellow circles) and slip rate (green circles) paleoseis-mic sites are shown by number including: Sites 1A-C. Schwartz and others (2014; in review); Sites 2A and 2B. Mériaux and others (2009); Site 3. Taylor and Bemis (2012); Carlson and others (2017); Sites 4A-F. Matmon and others (2006); Site 5. Koehler and others (2013); Site 6. Carver and others (2004); Site 7. Koehler and others (2011); Sites 8A-C. Schwartz and others (2012); Site 9. Seitz and others (2008); Site 10. Haeussler and others (2014); Site 11 Haeussler and others (2014); Seitz and others (2008); and Site 12. Personius and others (2015). Sites that contain both timing and slip rate data are shown as circles filled half yellow and half green. SGF = Susitna Glacier fault. Note: Due to the scale of the map, some sites overlap. Readers should consult original references for more accurate site locations. B. Previously reported slip rate estimates generally scaled to the map in A, showing a general westward decrease in slip rate. Names of sites from the original references are next to the respective slip rate, and/or color-coded by author.

are within the interior Alaska source region and have been grouped into the western, central, and eastern sections as defined above.

Reconnaissance-level paleoseismic studies along the central and eastern Denali fault are beginning to provide information on the timing of paleoearthquakes (Schwartz and others, 2003; 2012; 2014; Carlson and others, 2017). Along the 2002 rupture section, trenching results near Mentasta Pass (fig. $12 \mathrm{~A}$, site $8 \mathrm{~A}$ ) indicate that the penultimate earthquake occurred between A.D. 1319 and AD 1415 (587-683 yrs b02 [before 2002])
(Schwartz and others, 2012) and an older earthquake occurred between 705 and 1,070 yrs b02 (Schwartz and others, 2014). In the Chistochina Glacier area (fig. 12A, site 7), Koehler and others (2011) determined that the penultimate earthquake occurred after 550-660 yrs b02. Annual ring counts from damaged and scarred trees along the Denali fault in the Delta River area were used by Carver and others (2004) to infer surface rupture in 1912, possibly associated with the $M_{S}$ 7.2-7.4 earthquake that occurred on July 6, 1912 (fig. 12A, site 6). West of the 2002 rupture section, preliminary trenching results from three sites 
(fig. $12 \mathrm{~A}$, sites $1 \mathrm{~A}, 1 \mathrm{~B}$, and $1 \mathrm{C}$ ) suggest the occurrence of two surface faulting events in the last -900 years, between 100 and 370 yrs b02 and between 570 and 680 yrs b02 (Schwartz and others, 2014; in review). Based on these studies Schwartz and others (2014) estimated a recurrence interval of between 400 and 650 years for large earthquakes along the central Denali fault. At the Schist Creek site, approximately $11 \mathrm{~km}(6.8 \mathrm{mi})$ east of the Parks Highway (fig. 12A, site 12), trenching results reported by Personius and others (2015) indicate the occurrence of at least four surface rupturing earthquakes including an event between 200 and 400 years ago, an event $<1,200$ years ago, an event between 1,200 and 1,700 years ago, and an older event between 2,700 and 17,000 years ago. A trench across the fault in a debris-flow fan $-24 \mathrm{~km}(-15 \mathrm{mi})$ east of the Parks Highway (Koehler and others, 2013) documented the occurrence of at least three paleoearthquakes, however, dateable material was not recovered (fig. 12A, site 5). The longest paleoseismic record on the Denali fault was described at a site on a terrace of the Nenana River adjacent to the Parks Highway which indicated the occurrence of seven earthquakes in the last 7,000 years (Taylor and Bemis, 2012; Carlson and others, 2017) (fig. 12A, site 3). OxCal modelled constraints on the mean ages for the earthquakes identified in the Carlson and others (2017) study indicate that earthquakes occurred at $388 \mathrm{cal} \mathrm{BP}, 807 \mathrm{cal} \mathrm{BP}$, 1,282 cal BP, 2,652 cal BP, 3,402 cal BP, 5,673 cal $\mathrm{BP}$, and 6,987 cal BP.

Along the eastern Denali fault, $-24 \mathrm{~km} \quad(-15$ $\mathrm{mi}$ ) east of the junction between the Denali and Totschunda faults (fig 12A, site 8B), trenching studies by Schwartz and others $(2003 ; 2012)$ indicate the occurrence of four and possibly five paleoearthquakes during the past 2,600-2,800 years. In those studies, the penultimate earthquake was determined to have occurred between AD 1656 and AD 1900 (102-346 yrs b02), and two older earthquakes occurred $\geq$ 550-680 yrs b02, and $\leq 1,010-1,220$ yrs b02. At the Duke River in Yukon Territory along the eastern
Denali fault, trenching results from Seitz and others (2008) indicate that the most recent event postdates the $1.2 \mathrm{ka}$ White River ash and occurred prior to formation of shorelines of Kluane Lake, estimated to be 0.3-0.5 ka (fig. 12A, site 9). Earthquake timing data has not been developed for the western Denali fault.

Long-term geologic slip rates have been evaluated by two separate studies of offset glacial deposits along the central Denali fault by $10 \mathrm{Be}$ surface exposure dating and field measurement of the offsets at several sites (Matmon and others, 2006; Mériaux and others, 2009). Both studies evaluated the Slate Creek site (fig. 12A, sites $4 \mathrm{~A}$ and $2 \mathrm{~A}$ ), east of the Richardson Highway, and estimated latest Pleistocene slip rates of $12.0 \pm 1.8 \mathrm{~mm} / \mathrm{yr}(0.47 \pm 0.07 \mathrm{in} / \mathrm{yr}$ ) (Matmon and others, 2006) and $13.6 \pm 3.8 \mathrm{~mm} / \mathrm{yr}(0.54 \pm 0.15$ in/yr) (Mériaux and others, 2009). At Bull Creek, in Denali National Park (fig. 12A, site 2B), Mériaux and others (2009) estimated a slip rate of $6.7 \pm 1.2 \mathrm{~mm} / \mathrm{yr}$ $(0.26 \pm 0.05 \mathrm{in} / \mathrm{yr})$. At two sites, approximately $8 \mathrm{~km}$ $(5 \mathrm{mi})$ and $37 \mathrm{~km}$ (23 mi) east of the Parks Highway (Fig. 12A, sites 4B and 4C), Matmon and others (2006) report an average slip rate of $9.4 \pm 1.6 \mathrm{~mm} / \mathrm{yr}$ $(0.37 \pm 0.06 \mathrm{in} / \mathrm{yr})$. A similar, albeit slightly slower, slip rate for the central Denali fault $(7.5 \pm 0.7 \mathrm{~mm} /$ yr $[0.30 \pm 0.03 \mathrm{in} / \mathrm{yr}])$ was determined by Koehler and others (2013) based on the cumulative offset (43 to $48 \mathrm{~m}$ [141-158 ft]) of a debris flow estimated by cosmogenic 10Be exposure ages on surface boulders thought to have been abandoned around $6.5 \mathrm{ka}$ (fig. $12 \mathrm{~A}$, site 5). Along the western Denali fault (fig. 12A, site 10), cosmogenically dated offset landforms near Ripsnorter Creek indicate a slip rate of $-5 \mathrm{~mm} / \mathrm{yr}$ $(\sim 0.2$ in) (Haeussler and others, 2014). Geomorphic relations along the eastern Denali fault near Kluane Lake in Yukon Territory suggest a slip rate of 1.7-2.5 $\mathrm{mm} / \mathrm{yr}(0.7-0.10 \mathrm{in} / \mathrm{yr})$ and possibly up to $4 \mathrm{~mm} /$ yr (0.2 in/yr) (Haeussler and others, 2014; Seitz and others, 2008) (fig. 12A, site 11). Directly east of the Denali/Totschunda fault intersection (fig. 12A, site 4D), Matmon and others (2006) estimated a slip rate of $8.4 \pm 2.2 \mathrm{~mm} / \mathrm{yr}(0.3 \pm 0.09 \mathrm{in} / \mathrm{yr})$. Together these 
studies indicate that the slip rate is highest along the central Denali fault and decreases to the west and east (fig. 12) consistent with geodetic $(6.5-9 \mathrm{~mm} / \mathrm{yr}$ [0.26-0.35 in/yr]) and InSAR (10 mm/yr [0.39 in/ $y r])$ measurements of strain accumulation along the central part of the fault (Fletcher, 2002; Biggs and others, 2007), and a westward decrease in cumulative slip (Plafker and Berg, 1994).

The decrease in slip rate toward the west has been attributed to a combination of indentation (related to Yakutat collision), rotation and internal deformation of the southern Alaska block, and transfer of slip to faults north of the Alaska Range (Haeussler and others, 2014). Haeussler and others (2014) infer that thrust faults that splay to the south off the central Denali fault accommodate transpressional deformation across a wide, distributed zone. Potentially active faults in this zone include the Broxson Gulch, Talkeetna, McCallum-Slate Creek, Bull River, and other unnamed faults (fig. 5) that together comprise the Southern Foothills fold-and-thrust belt defined earlier in this paper. Definitive Quaternary offsets have not been documented on these structures. The only known active faults in the zone are the Susitna Glacier thrust and Pass Creek fault (described earlier).

The Susitna Glacier thrust extends along the southern flank of the Alaska Range near the West Fork Glacier and along the northwestern valley margin of the Susitna Glacier (fig. 5). The fault was undiscovered prior to the 2002 Denali fault earthquake, during which it produced a $48-\mathrm{km}$-long (30-mi-long) surface rupture characterized by a $1-\mathrm{km}$-wide (0.62-mi-wide) zone of folds, pressure ridges, and thrust and backthrust scarps up to 5.4 and $4 \mathrm{~m}$ high $(17.7$ and $13.1 \mathrm{ft}$ high), respectively (Crone and others, 2004). Pre-2002 fault scarps were also identified by Crone and others (2004), most confidently where the 2002 rupture was superimposed on large, old scarps, suggesting the occurrence of older paleoruptures.

The right-lateral Totschunda fault (figs. 11 and 12) extends approximately $200 \mathrm{~km}$ (124 mi) southeast from its junction with the Denali fault at
Mentasta Pass to the Canada border (Richter, 1976; MacKevett, 1978) and includes previously named sections including the Cooper Pass and Cross Creek faults (Richter and Matson, 1971). The fault is characterized by broadly curved, overlapping and branching fault sections, has accumulated $-10 \mathrm{~km}$ (-6.2 mi) of cumulative displacement, and is geomorphically well expressed by scarps, sag ponds, and offset glacial deposits and drainages (Richter and Matson, 1971). Early efforts to characterize the fault reported displacement of late Wisconsin glacial deposits from 90 to $330 \mathrm{~m}$ ( 295 to $1,083 \mathrm{ft}$ ) and estimated an average slip rate of $16 \mathrm{~mm} / \mathrm{yr}(0.6 \mathrm{in} / \mathrm{yr}$ ) (Richter and Matson, 1971). Plafker and others (1977) noted that soils containing the White River ash (1,520-1,720 years B.P.) were not displaced. The northern $66 \mathrm{~km}$ (41 mi) of the fault ruptured in conjunction with the Denali fault in the 2002 Denali fault earthquake (Haeussler and others, 2004). In a trench immediately south of the Denali-Totschunda intersection along the 2002 rupture trace (fig. 12A, site $8 \mathrm{C}$ ), Schwartz and others (2012) determined that the penultimate earthquake occurred between AD 1267 and AD 1424 (578-735 yrs b02). Based on offset of cosmogenically dated landforms along the fault (fig. 12A, sites $4 \mathrm{E}$ and $4 \mathrm{~F}$ ), Matmon and others (2006) estimated a late Pleistocene-Holocene slip rate of $6.0 \pm 1.2 \mathrm{~mm} / \mathrm{yr}(0.23 \pm$ $0.05 \mathrm{in} / \mathrm{yr}$ ). Although the northwestern section of the Totschunda fault ruptured during the 2002 Denali fault earthquake, the southern part is a likely source of a future large earthquake.

Along the northern flank of the Alaska Range north of the Denali fault, a system of imbricate thrust faults, the Northern Foothills fold-and-thrust belt (NFFTB), extends over $500 \mathrm{~km}(310 \mathrm{mi})$ from Denali to the Tok River valley (fig. 11). These faults have uplifted and warped the Plio-Pleistocene Nenana Gravel and glacial deposits, forming a series of anticlines and synclines along the northern foothills of the Alaska Range (Péwé and others, 1966; Wahrhaftig, 1958). Geomatrix Consultants (1997) and Hanson and others (2002) 
interpreted the system as a fold-and-thrust belt and Bemis and others (2012) divided it into the Kantishna Hills, western, and eastern sections based on differences in structural style (fig 2 in Bemis and others, 2012). A M 7.2 event occurred in 1947 at the front edge of the northern foothills of the Alaska Range. Although the source mechanism of this event is poorly constrained, observations from modern seismicity are consistent with ongoing thrust deformation on the north side of the central Alaska Range. The Kantishna seismic cluster, located just north of the Denali fault in the Denali National Park boundary area, produces frequent, small, shallow earthquakes and produced a shallow M 2 earthquake every few days in 2010. The largest earthquakes in this cluster are on the order of magnitude 5 and are rare. This cluster is believed to accommodate deformation between the Denali fault and Minto flats seismic zone to the north.

Maximum horizontal shortening across the western part of the system has been estimated at -3 mm/yr ( 0.1 in/yr) (Bemis and Wallace, 2007; Bemis, 2004). The deformation is accommodated along active faults including the Billy Creek, Canteen, Cathedral Rapids, Ditch Creek, Donnelly Dome, Dot “T” Johnson, East Fork, Eva Creek, Glacier Creek, Gold King, Granite Mountain, Healy Creek, Healy, Hunter, Kansas, Creek, Macomb Plateau, McGinnis Glacier, Molybdenum Ridge, Mystic Mountain, Panoramic, Park Road, Peters Dome, Potts, Red Mountain, Rex, Stampede, Trident, and Trident Glacier faults, as well as the Kantishna Hills anticline and the Northern Foothills thrust (figs. 4-6 in Bemis and others, 2012). Although Thorson (1979) inferred the occurrence of three post-latest Wisconsin faulting events on the Healy fault, information on earthquake timing and slip rates for individual faults of the NFFTB is limited.

Using cumulative dip-slip offsets and the estimated ages of fluvial terraces, Bemis (2010) determined slip rates of $0.25-1 \mathrm{~mm} / \mathrm{yr}(0.01-0.04 \mathrm{in} / \mathrm{yr})$ for the Stampede and Northern Foothills Thrust (fig. 11). This rate is slightly higher than the $0.1-0.4$ $\mathrm{mm} / \mathrm{yr}(0.004-0.016 \mathrm{in} / \mathrm{yr})$ estimated by Hanson and others (2002) based on topographic profiles of glacial outwash terraces and apparent structural relief of the Nenana Gravel along the Nenana River. Offset glacial moraines (fig 11, site 1) indicate that the Canteen fault has a lateral slip rate of $1-2 \mathrm{~mm} /$ yr (0.04-0.08 in/yr) (Carver and others, 2008a). A shortening rate across the Granite Mountain fault (fig. 11, site 2) of between 1.4 and $3.5 \mathrm{~mm} / \mathrm{yr}(0.06$ and $0.14 \mathrm{in} / \mathrm{yr}$ ) has been estimated using a vertical separation of $>2 \mathrm{~km}$ (>1.2 mi) of the Nenana Gravel (Bemis, 2010). The Park Road fault vertically displaces a Riley Creek glaciation outwash terrace by $-12 \mathrm{~m}(-40 \mathrm{ft}$ ) (Koehler and others, 2016) (fig. 11, site $3)$. Assuming that the age of the terrace postdates the maximum Riley Creek glacial advance around -17 ka (Ten Brink and Waythomas, 1985), the minimum late Pleistocene uplift rate for the Park Road fault is $-0.7 \mathrm{~mm} / \mathrm{yr}(-0.03 \mathrm{in} / \mathrm{yr})$.

Several paleoseismic trenching studies provide information on the timing of earthquakes along the NFFTB. Along the Healy fault Bemis (2010) documented at least three and possibly four earthquakes that postdate deposition of a $>23 \mathrm{ka}$ fluvial terrace gravel and inferred that the most recent earthquake occurred sometime during the years 1,528-1,176 cal yrs B.P. (fig. 11, site 4). Trenches along the Healy Creek fault (fig. 11, site 5) indicate the occurrence of one latest Pleistocene earthquake and suggest that the fault has not experienced a surface rupture for at least 7,000 years (Bemis, 2010). In the vicinity of Windy Creek (fig. 11, site 11), shallow excavations provide evidence that the most recent surfacerupturing earthquake along the Northern Foothills thrust occurred before 26,591-25,751 cal yrs B.P. (Bemis, 2010). Additional trenches and gravel pit exposures across backthrust scarps $-900 \mathrm{~m}(-1,950$ $\mathrm{ft}$ ) south of the projected trace of the Northern Foothills thrust along the Nenana River (fig. 11, site 6) provide evidence for deformation that occurred between 4,800 and 1,800 cal yrs B.P. and indicate a 
wide zone of deformation (Devore and others, 2012). In this same area (fig. 11, site 6), a trench investigation across another small backthrust scarp indicates the occurrence of at least one earthquake prior to $-5,000$ cal yrs B.P. (Koehler and others, 2016). Excavations across the Dot " $\mathrm{T}$ " Johnson fault in the vicinity of Sam Creek (fig. 11, site 7) indicate the occurrence of an earthquake after 7,980-7,850 cal yrs B.P. and several older latest Pleistocene events that predate 7,980-7,850 cal yrs B.P. and may be older than 11,350-11,210 cal yrs B.P. (Carver and others, 2008a, 2010). At Sears Creek along the Dot "T" Johnson fault (fig. 11, site 8), Carver and others (2010) iden-

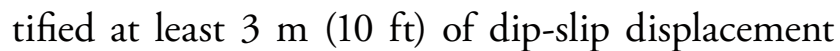
of fluvial gravels interpreted to have occurred more recently than 4,430-3,230 cal yrs B.P. Excavations across a graben in the crest of a large growth anticline along the Cathedral Rapids fault (fig. 11, site 9) documented colluvial fills interpreted to be related to at least four latest Pleistocene earthquakes and a Holocene earthquake that occurred after $\sim 8 \mathrm{ka}$ (Carver and others, 2010). An additional exposure in a trench across a small scarp at the base of the fold scarp indicated that the most recent earthquake occurred after AD 1650 (Carver and others, 2010). Based on stratigraphic relations exposed in a trench across a fold scarp along the Cathedral Rapids fault (fig. 11, site 10), Koehler and Woods (2013) interpreted the occurrence of at least one earthquake that postdates the development of tilted buried soil developed around $850 \mathrm{cal}$ yrs B.P.

In the general vicinity of Fairbanks, a series of north-northeast-trending left-lateral strike-slip seismic zones including the Rampart, Minto Flats, Fairbanks, and Salcha seismic zones have been the source of numerous felt earthquakes and all have produced $M \geq 6$ shocks (fig. 11). The region extends between the Kaltag-Tintina faults to the north and the Denali fault to the south and has produced $787 \mathrm{M}$ $\geq 4.0$ events, 111 moderate events, 27 strong events, and five major earthquakes over the last -60 years. Notable among these earthquakes are the $1968 \mathrm{M}$
7.1 Rampart, 1985 M 6.1 Dall City, 1995 M 6.0 Minto Flats earthquake, and three M 5.0-5.7 events in 1967 near Fairbanks (Ruppert and others, 2008; Ratchkovski and Hansen, 2002; Gedney and others, 1969; Estabrook, 1985; Dixon, 1988; Gedney and Berg, 1969). The largest event was the 1937 M 7.3 earthquake in the Salcha seismic zone (Bramhall, 1938). East of $146^{\circ} \mathrm{W}$ longitude the seismicity levels in the interior Alaska source region between the Tintina fault in the north and the Denali fault in the south decrease considerably. The geologic evidence, however, indicates the presence of additional northeast-striking lineaments and sinistral-slip faults. Although seismically active, the interior Alaska seismic zones are not expressed at the surface with the possible exception of the Salcha seismic zone; their future seismic potential and ability to produce large surface-rupturing earthquakes is poorly constrained.

The Minto Flats seismic zone is associated with two distinct lineaments of seismicity that overlap by $67 \mathrm{~km}$ (42 mi) and are separated by $10 \mathrm{~km}$ (6 mi) across the $8 \mathrm{~km}$ (5 mi) deep Nenana basin (Tape and others, 2013, 2015). The geometry of this narrow and deep basin bounded by faults indicates that the style of deformation is consistent with left-lateral transtension (Tape and others, 2015). A M 5.1 earthquake occurred August 30, 2014, near the northern part of the zone and generated a vigorous aftershock sequence of more than 1,500 events, including two events $M>4$ (AEC, 2016). The southern part of the zone experienced $\mathrm{A} \mathrm{M}_{\mathrm{W}} 5.7$ earthquake on November, 29, 2000 (Tape and others, 2015). The southeastern seismic lineament coincides with a $12-\mathrm{km}$-long (7.5-mi-long) down-to-the-northwest fault mapped by Péwé and others (1966) along the Tanana River floodplain from Goldstream Creek to the vicinity of Dunbar. This lineament is associated with a nearly vertical approximately 2-3-m-high (6.6-10-ft-high) escarpment. Reconnaissance investigations along this scarp indicate that it has cuspate morphology in map view and sinuous abandoned meander channels of the Tanana River extend along the base of the scarp, 
suggesting that it is a fluvial terrace riser and not a tectonic feature (Koehler and others, 2016). Despite the lack of surficial evidence of tectonic deformation, Tape and others (2015) used continuity of microseismicity, style of faulting, and empirical relations between fault length and magnitude to suggest that the fault zone is capable of $\mathrm{M}_{\mathrm{W}} 7.0$ to 7.5 earthquakes. Tape and others (2015) also used magnitude frequency relations to estimate an -100 -year recurrence interval for earthquakes of $\mathrm{M} \geq 6.0$.

The 1937 earthquake along the Salcha seismic zone produced extensive ground failures in the epicentral area, but there was no documented evidence of surface rupture (Bramhall, 1938). Reconnaissance helicopter surveys and interpretation of new lidar hillshade images indicate the presence of aligned mounds in the epicentral region of this event (fig. 13). Although the origin of the mound-like features observed along the Salcha River valley is unknown at this time, possible explanations include, tectonic pop-up ridges, remnant sand dunes, pingos, and/or other cryogenic landforms. Additional research is necessary to address whether they are related to active tectonic processes.

The Dall Mountain fault extends $30 \mathrm{~km}(18.6$ mi) from Dall Mountain in the north to the vicinity of Guishiemana Lake at its southern end (fig. 11). The fault is characterized by a moderately sharp rangefront and down-to-the-west normal displacement. Brogan and others (1975) described evidence for recent fault activity including a distinct escarpment of variable height, a change in gradient of several streams that cross the scarp, and numerous springs. Subsequent evaluations have only been at the reconnaissance level, but indicate that the majority of the fault scarp displaces bedrock or thin colluvial deposits (fig. 14). Along the southern part of the fault a steep, 6.5-m-high (21.3-ft-high) scarp appears to cut alluvial fan deposits; however, further investigation is needed to determine whether the alluvium was deposited over a pre-existing bedrock escarpment or if the fan is displaced. Based on the rounded morphology at the scarp crest and lack of well-developed facets, Koehler and others (2012a) inferred a slip rate of $<0.2 \mathrm{~mm} / \mathrm{yr}$ (<.01 in/yr) for the Dall Mountain fault.

In southwestern Interior Alaska, the Iditarod-Nixon Fork fault traverses the Kuskokwim Mountains for more than $370 \mathrm{~km}$ (230 mi), extending from Aniak to the vicinity of the Sischu Mountains and represents a seismic hazard to the village of McGrath (figs. 11 and 15). The fault is seismically quiet and only the central part has evidence for Quaternary deformation. The fault is

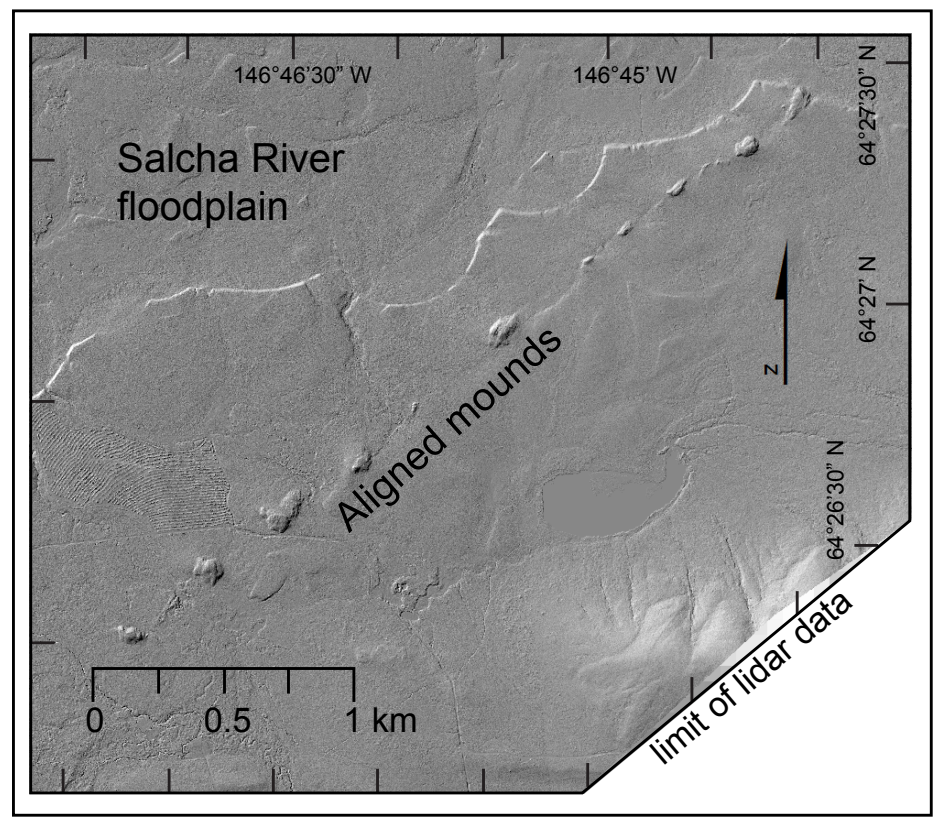

Figure 13. Lidar derived 1-m hillshade showing aligned mounds along the Salcha River seismic zone. The origin of these features is un-known; however, their linear arrangement in the epicentral region of the 1937 M 7.3 earthquake suggests that they could be related to tectonic processes. Alternative explanations include sand dunes or cryogenic processes. 


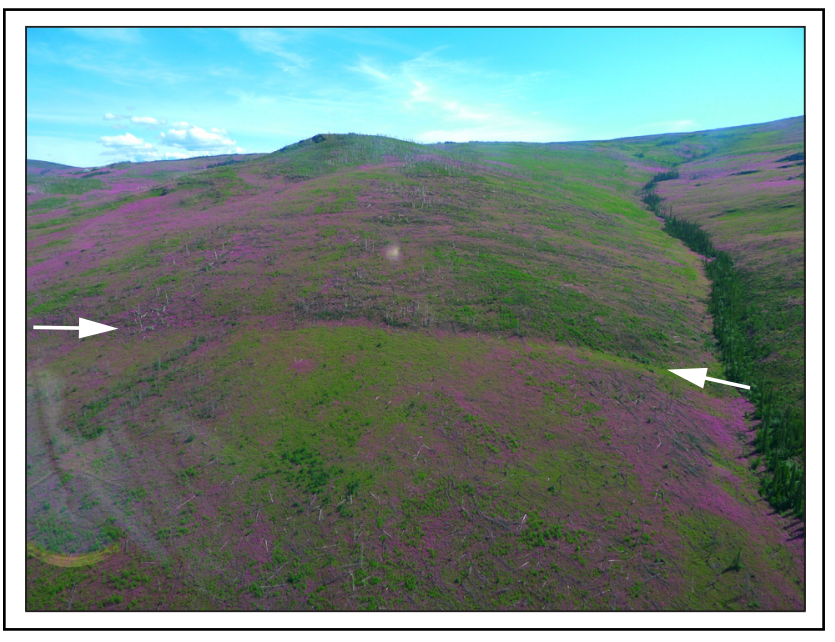

Figure 14. View to the east of prominent side-hill scarp associated with the Dall Mountain fault along the western side of the Dall Mountains (fault shown between arrows). Location of photo is in the vicinity of GPS coordinate $66.401442^{\circ},-149.720578^{\circ}$.

characterized by prominent linear valleys and scarps along the Iditarod and Owhat rivers, Bonanza Creek, the headwaters of Moore Creek and Fourth of July Creek, and segments of the Takotna River and Nixon Fork River (Mertie and Harrington, 1924; Cady and others, 1955; Fernald, 1960) (figs. 11 and 15). Pleistocene and possibly Holocene activity along the fault was inferred by Bundtzen and others (1988), who described a speculative right-lateral offset of stream placer deposits and channels along Moore Creek that resulted in uplift and abandonment of paleochannels up to $6 \mathrm{~m}(-20 \mathrm{ft})$ above the modern floodplain. Based on the speculative nature of these observations and the lack of detailed paleoseismic studies, further investigation related to the fault's relative activity and seismic potential is warranted.

In northern interior Alaska, the right-lateral, active Kaltag and Tintina faults together comprise a northward convex arc (somewhat parallel to the Denali fault) that extends across the entire state (figs 1A, 11, and 16). Despite diffuse seismicity and subtle geomorphic expression, these faults have produced some notable earthquakes including the 1972 M 5.3 earthquake along the Tintina fault and the 2000 M 5.6 event along the Kaltag fault. Although the two faults are not directly linked, a series of east-northeast-trend- ing faults in bedrock in the Tanana B-1 Quadrangle (Reifenstuhl and others, 1997) might accommodate deformation within a subtle left-step in the system. Several faults in this area, including the Kaltag Extension, Victoria Creek, and Tozitna faults (fig. 11), are along strike of the Tintina fault and are associated with long linear valleys, bedrock pressure ridges, and wind gaps (Weber and others, 1992). These potentially active faults might also serve to link the Tintina and Kaltag faults, however evidence of Quaternary activity has not been documented.

The Kaltag fault, which extends from Unalakleet to Tanana (figs. 11 and 16), has displaced the margin of the Yukon-Koyukuk basin approximately 100 to 130 km (62-81 mi) (Patton and Hoare, 1968). The fault is associated with moderate seismicity along its entire length, including several M 5 events. The Yukon River follows the fault, which is buried by the river and its associated late Holocene floodplain deposits that are not displaced. Along the northern flank of the Kaiyuh Mountains, the Kaltag fault is associated with subtle degraded bedrock escarpments, large bedrock shutter ridges, and a distinct alignment of pingos (fig 17). The pingos are small (2-3 $\mathrm{m}$ high [6.6-10 ft high] by 5-15 m long [16-49 ft long]), oval-shaped mounds, and may be a product of active springs along the fault. Despite the presence of tectonic geomorphic features along the fault, youthful scarps extending across the landscape between relatively old bedrock shutter ridges have not been identified. Patton and Hoare (1968) suggest recent tectonic deformation along the fault in the vicinity of Kaltag, based on the presence of diverted streams, offset spurs, fault-bounded bedrock slivers, sharply delineated changes in fine drainage and vegetation patterns, and inferred rightlateral separation of stream drainages by as much as $0.8 \mathrm{~km}(0.5 \mathrm{mi})$. These observations have not been verified using modern paleoseismic techniques, and thus the seismic potential of the Kaltag fault remains poorly characterized.

The Tintina fault zone extends from the vicinity of Eagle to the Victoria Creek Valley and is the 


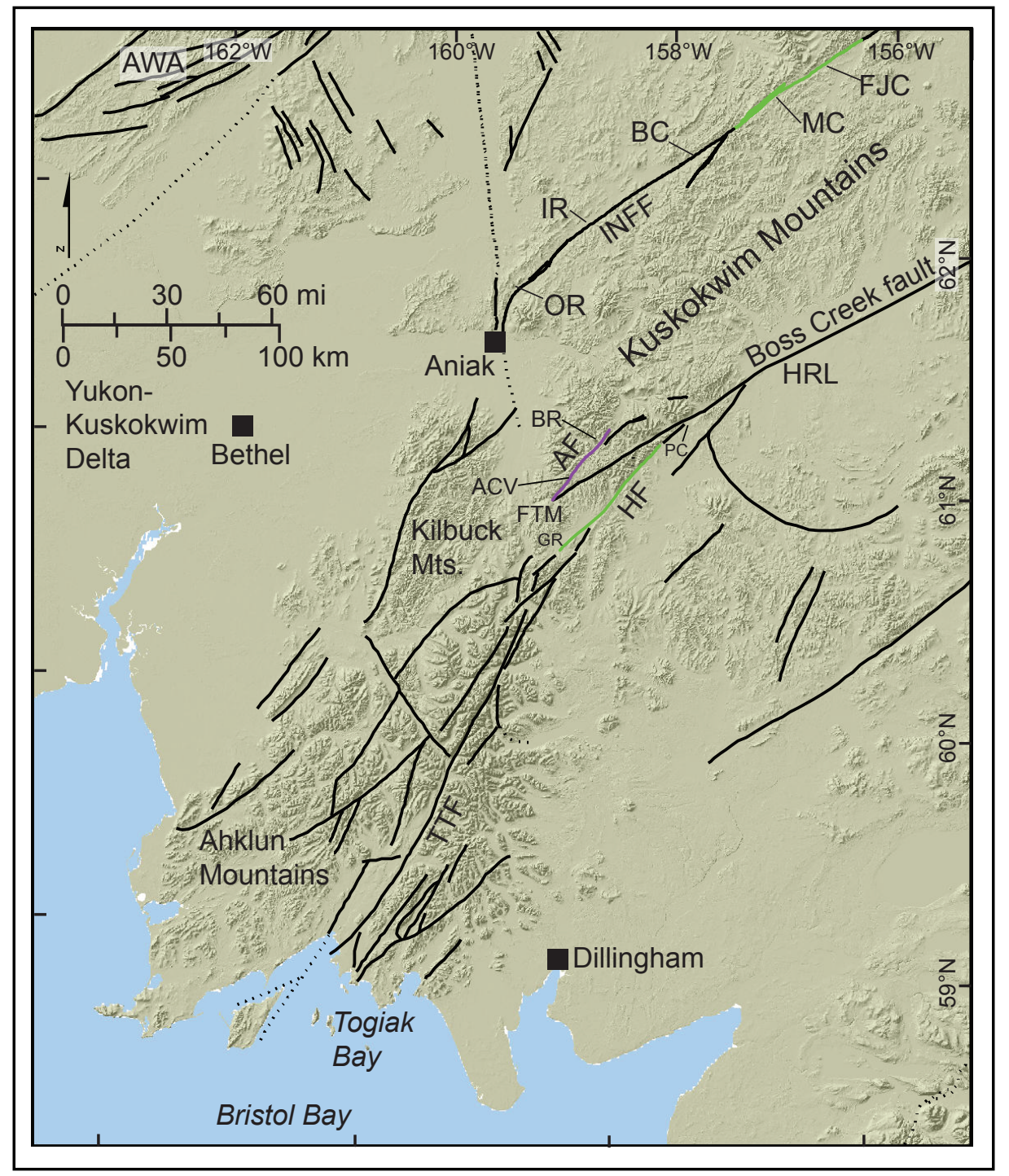

Figure 15. Map of the Bristol Bay and Yukon-Kuskokwim Delta area (southern part of the Western Alaska and Bering Sea source region), showing known active and potentially active Quaternary faults. Fault colors indicate relative age from Koehler (2013); see figure 2 for defini-tions. IR = Iditarod River, $\mathrm{MC}=$ Moore Creek, FJC = Fourth of July Creek, BC = Bonanza Creek, OC = Owhat Creek, TTF = Togiak-Tikchik fault, $\mathrm{AF}=$ Atsaksovluk fault, $\mathrm{HF}=$ Holitna fault, INFF = Iditarod-Nixon Fork fault, GR = Gemuk River, $\mathrm{PC}=$ Portage Creek, HRL = Holitna River lowlands, ACV = Atsaksovluk Creek Valley, FTM = Flat Top Mountain, AWA $=$ Andrafsky wilderness Area.

western extension of a major tectonic strike valley in Canada (fig. 11). Geologic maps depict the fault as a southern trace named the Hot Springs fault, and three northern traces: from east to west, the Tintina fault, Medicine Lake lineament, and Preacher Creek lineament (Foster, 1976; Brabb and Churkin, 1969; Foster and others, 1983). In the vicinity of the Victoria Creek Valley the Tintina fault splits into several major faults including the Tozitna, Victoria Creek, and Kaltag Extension faults, and an unnamed fault (Weber and others, 1992). These faults are associated with large bedrock shutter ridges, wind gaps, and linear valleys; however, they are not expressed in youthful deposits. Quaternary activity has only been documented along two lineaments in the Tintina fault zone. Weber and
Foster (1982) documented a 6-m-high (19.7-ft-high) scarp and a possible right-lateral stream offset along the Preacher Creek lineament. The Medicine Lake lineament displaces Yukon River alluvium and loess across a 6-13-m-high (19.7-42.7-ft-high) scarp (Foster and others, 1983; Davies, 1972). These two lineaments are associated with moderate seismicity (Gedney and others, 1972); however, the eastern part of the fault system is relatively devoid of seismicity. Paleoseismic studies have not been performed along the Tintina fault system.

\section{WESTERN ALASKA AND BERING SEA SOURCE REGION}

The western Alaska and Bering Sea source region (fig. $1 \mathrm{~B}, 15$, and 16 ) is a relatively quiescent region, but 


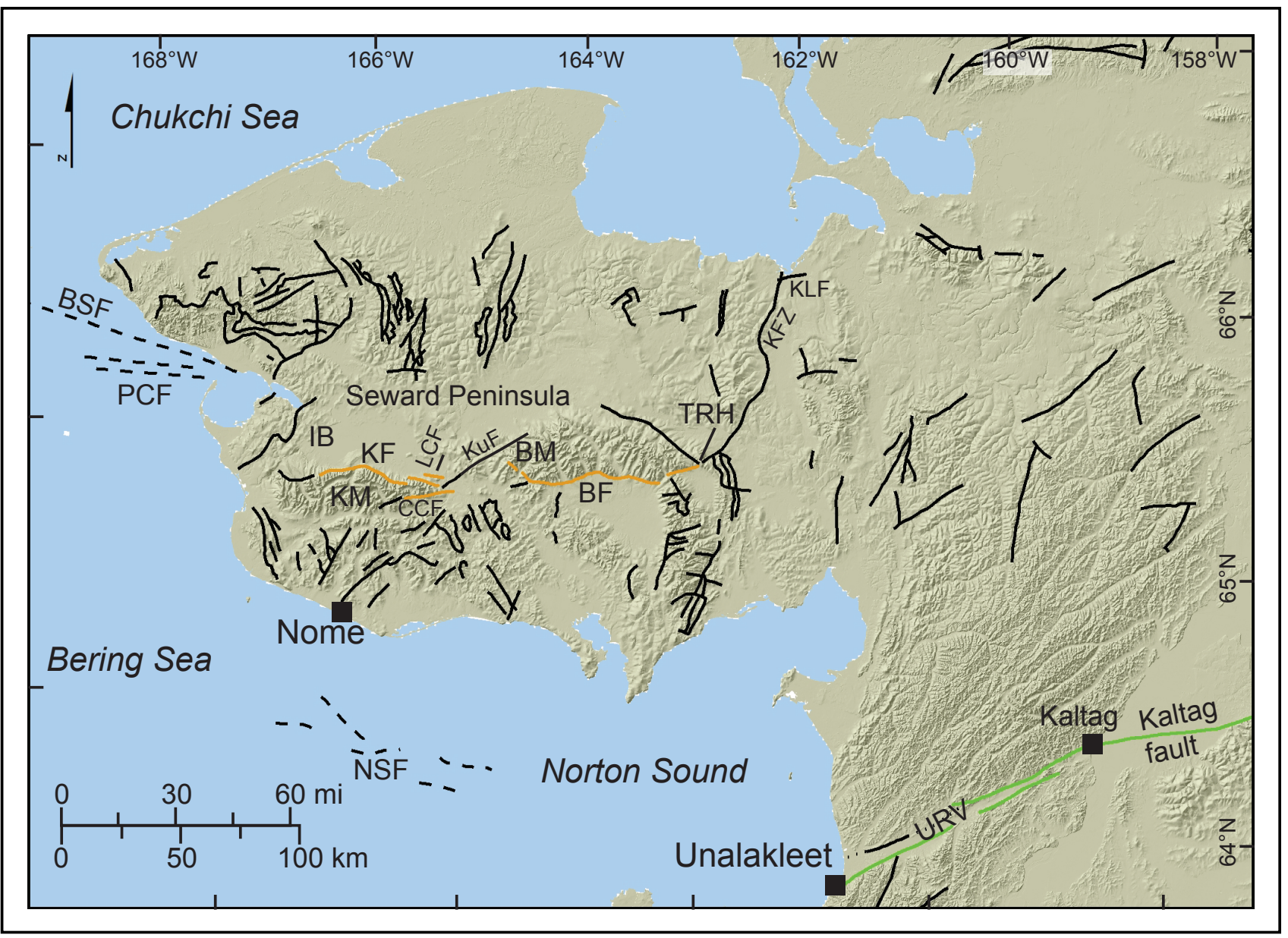

Figure 16. Map of the Seward Peninsula area in the northern part of the Western Alaska and Bering Sea source region, showing known active and potentially active Quaternary faults. Fault colors indicate relative age from Koehler (2013); see figure 2 for definitions. $\mathrm{MB}=$ Mount Bendeleben, $\mathrm{KM}=$ Kigluaik Mountains, $\mathrm{BF}=$ Bendeleben fault, KF, Kigluaik fault, TRH, Tubutulik River headwaters, $\mathrm{IB}=$ Imuruk Basin, $\mathrm{BSF}=$ Bering Straight fault zone, $\mathrm{PCF}=$ Port Clarence fault zone, NSF = Norton Sound fault zone, $\mathrm{KLF}=\mathrm{Kiwalik}$ Lagoon fault, KFZ = Kugruk fault zone, Kuf = Kuzitrin fault, LCF = Lararee Creek fault, URV = Unalakleet River Valley.

it has generated numerous moderate earthquakes over the last 50 years including $62 \mathrm{M} 4.0-5.0$ and five $\mathrm{M}$ $\geq 5.0$ earthquakes. The densest seismic activity occurs in the southern and northeastern parts of the Seward Peninsula, where moderate normal and strike-slip earthquakes are related to north-south extension. The most recent notable earthquake (2014 M 5.6) occurred north of the Seward Peninsula and was associated with normal faulting and a vigorous aftershock sequence (the Noatak swarm). The extension in the region may be driven by clockwise rotation of the hypothesized Bering plate (Freymueller and others, 2008) that is defined by crustal velocities measured using GPS. This poorly defined microplate boundary zone is interpreted to extend from northwestern Alaska in the vicinity of the Seward Peninsula and along the upper Yukon River into central interior Alaska. Zones of diffuse seismicity also occur offshore around St. Lawrence Island and within the Ahklun and Kilbuck Mountains northwest of Dillingham (fig. 15). In 2010 an unusual series of earthquakes was recorded about $260 \mathrm{~km}$ (162 mi) west of St. Matthew Island. The M 6.5 main shock was preceded by a M 4.3 foreshock one minute earlier, and a M 6.3 aftershock five minutes later.

Active faults in the western Alaska-Bering Sea source region include the Bendeleben and Kigluaik faults on the Seward Peninsula and faults associated 


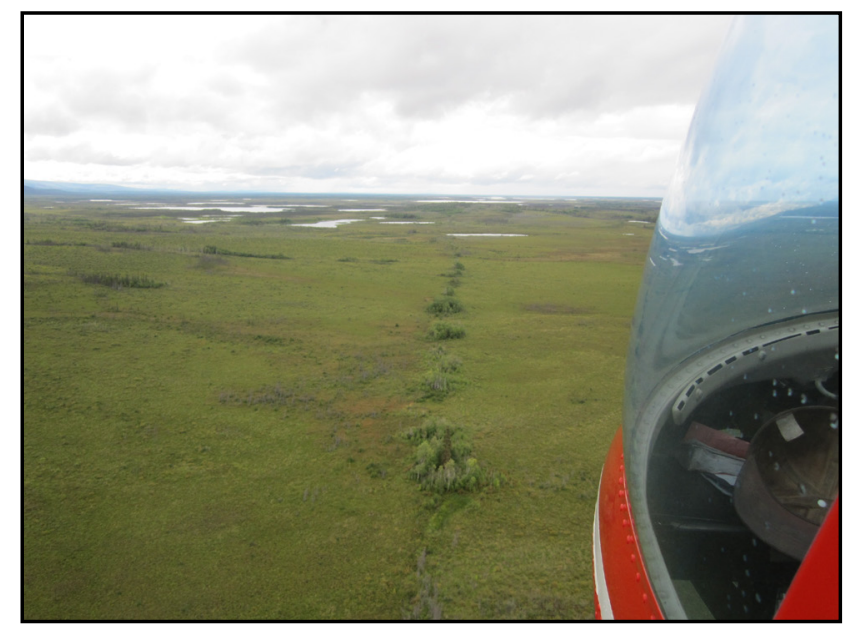

Figure 17. View to the southwest along the Kaltag fault where it projects along the northern flank of the Kaiyuh Mountains toward the Yukon River floodplain. The trace of the fault is marked by pingos aligned with trees through the center of the photo. Photo taken from GPS coordi-nate $64.457867^{\circ},-157.520967^{\circ}$

with the western extension of the Denali fault in the Holitna River and Kilbuck Mountains areas. A series of northeast-trending faults have been mapped in bedrock across the Andreafsky Wilderness area north of the Yukon-Kuskokwim delta; however, Quaternary deformation has not been documented on these faults. Note that the western part of the Kaltag fault in the Unalakleet River valley between Kaltag and Unalakleet and the Iditarod-Nixon Fork fault in the northwestern Kuskokwim Mountains and Iditarod River valley (described in the Interior Alaska source region described earlier) also occur in the western Alaska-Bering Sea source region.

North-south extensional deformation characteizes the neotectonic framework in the Seward Peninsula area consistent with seismicity observations, extensive basalt lavas, parallel alignments of volcanic vents, and active normal faults (Page and others, 1991; Dumitru and others, 1995; Biswas and others, 1986). This deformation is accommodated by normal faulting along the east-west-trending Kigluaik and Bendeleben faults, which together form a zone of active faulting about $175 \mathrm{~km}$ (109 $\mathrm{mi})$ in length. The north-dipping Kigluaik fault separates the Kigluaik Mountains from the Imuruk Basin along a sharp rangefront. Post-Wisconsin glacial landforms include associated benches, notches, and scarps with vertical displacements between 4 and $10 \mathrm{~m}$ (13 and $33 \mathrm{ft}$ ) (Hudson and Plafker, 1978; Kaufman and others, 1989; Kaufman, 1986). The south-dipping Bendeleben fault extends from Mt. Bendeleben to the headwaters of the Tubutulik River and is associated with clear scarps, observable on satellite imagery, along its south-facing rangefront. Geomorphic indicators of late Pleistocene and Holocene activity along the Bedeleben fault include slope breaks, saddles in colluvium, and scarps in glacial moraines and bedrock that range from 2 to $8 \mathrm{~m}$ high (6.6 to $26.2 \mathrm{ft}$ high) (Hudson and Plafker, 1978; Kaufman, 1986). Diffuse seismicity and displaced Quaternary landforms indicate that the Kigluaik and Bendeleben faults are capable of generating damaging earthquakes. However, based on their subtle geomorphic expression, poor age control on displaced deposits, and lack of paleoseismic studies, Koehler and others (2012a) assigned a slip rate of $0.2-1 \mathrm{~mm} /$ yr (0.01-0.04 in/yr) for these faults. Additional poorly documented faults in the Seward Peninsula area (Plafker and others, 1994a; Sainsbury, 1972) may also be capable seismic sources. These faults include the Bering Strait, Norton Sound, and Port Clarence fault zones, the Kugruk, Kilwalik Lagoon, Kuzitrin, Labaree Creek, and Crater Creek faults, among others (Plafker and others, 1994a) (fig. 16).

In the southern part of the western Alaska-Bering Sea source region, active faults associated with the Denali fault system include the Boss Creek, Holitna, Atsaksovluk, and Togiak-Tikchik faults (fig. 15). These faults are differentiated from the Denali fault in interior Alaska based on their subdued geomorphic expression and slower slip rates. Several earthquakes $(\mathrm{M}<5)$ have occurred in the vicinity of these faults, however, no major earthquakes have occurred in recorded history. Observations on the relative activity of these faults are limited and detailed paleoseismic studies have not been undertaken. 
The Boss Creek fault extends across the Holitna River lowlands to the southern margin of the Kuskokwim Mountains (fig. 15) and is expressed by discontinuous, poorly defined slope breaks and by alignment of major drainages or topographic features (Plafker and others, 1977). Previous mapping has shown the Boss Creek fault as concealed beneath Quaternary sediments (Cady and others, 1955; Decker and others, 1995) and no Holocene or Quaternary offsets have been observed (Plafker and others, 1977). The Holitna fault is a northwest-dipping reverse fault that extends along the southeastern margin of the Kuskokwim Mountains for $-76 \mathrm{~km}$ ( $-47 \mathrm{mi}$ ) between the Gemuk River and Portage Creek, which drain to the Holitna River lowlands (fig. 15). The fault is expressed as a distinct, continuous, southeast-facing scarp as high as $6 \mathrm{~m}(19.7 \mathrm{ft})$ in the Pliocene-aged Sleetmute surface, a late-mature rolling upland, as well as across Quaternary glacial deposits and loess (Cady and others, 1955). The scarp has been modified by surficial processes and the recency of deformation is unknown. However, ongoing stream dissection in the Sleetmute surface is inferred to be related to active uplift along both the Boss Creek and Holitna faults (Cady and others, 1955).

The Atsaksovluk fault extends for $-40 \mathrm{~km}(-25$ mi) along the northwestern side of the Atsaksovluk Creek valley from Flat Top Mountain to the headwaters of the Buckstock River (fig. 15). Cady and others (1955) describe the fault trace in surficial deposits in the vicinity of Timber Creek northwest of Flat Top Mountain but the features they describe do not appear to be on the fault trace and they do not discuss the relative age of displacement. The Togiak-Tikchik fault extends more than $210 \mathrm{~km}$ (130 mi), from Togiak Bay to the vicinity of the Holitna fault near the Gemuk River (fig. 15). The southern part of the fault is characterized by a straight, westfacing escarpment (Hoare, 1961). Based on bedrock relations, this apparent east-side-up vertical displacement transitions northward to west-side-up motion where the fault is characterized by linear drainages and divides (St. Amand, 1957; Hoare, 1961). The opposing directions of the sense of slip along the fault suggest it is a lateral slip fault. Although no evidence of Holocene or Quaternary movement along the fault has been identified (Plafker and others, 1977; Hoare and Coonrad, 1961), the gross geomorphology and apparent projection into the Holitna fault suggest it could be active.

The limited available information for the faults of the western Denali fault system indicates that they are characterized by low rates of activity. Based on this information, Koehler and others (2012a) classified the relative activity of the Holitna and Atsaksovluk faults as mid-Quaternary and Quaternary, respectively, and the Boss Creek and Togiak-Tikchik faults as suspicious. Due to the lack of detailed studies, the seismic potential and relative risk to Alaska posed by these structures remains unknown.

\section{NORTHERN ALASKA AND BROOKS RANGE SOURCE REGION}

Intraplate earthquakes in the northern Alaska and Brooks Range source region (figs. $1 \mathrm{~B}$ and 18) are associated with the Brooks Range orogen, gravitational deformation of thick sedimentary sequences, and crustal reorganization. The northwestern part of this source region is relatively aseismic, however the general lack of detectable earthquakes is likely a product of minimal instrumentation and does not necessarily indicate an absence of active faults. The northeastern part of the source region contains a broad earthquake band, extending from the Brooks Range toward the Beaufort Sea, which has been associated with more than 20 historical earthquakes of M 4.0-5.3 with focal mechanisms that indicate strike-slip and normal faulting events indicative of north-northwest compression and northeast extension. In the Brooks Range itself, more than 70 moderate earthquakes of M 4.0-5.7 and four $M>5.0$ shallow earthquakes have occurred over the last 60 years. Earthquake swarms along the southern margin of the Brooks Range, which include more than 20 


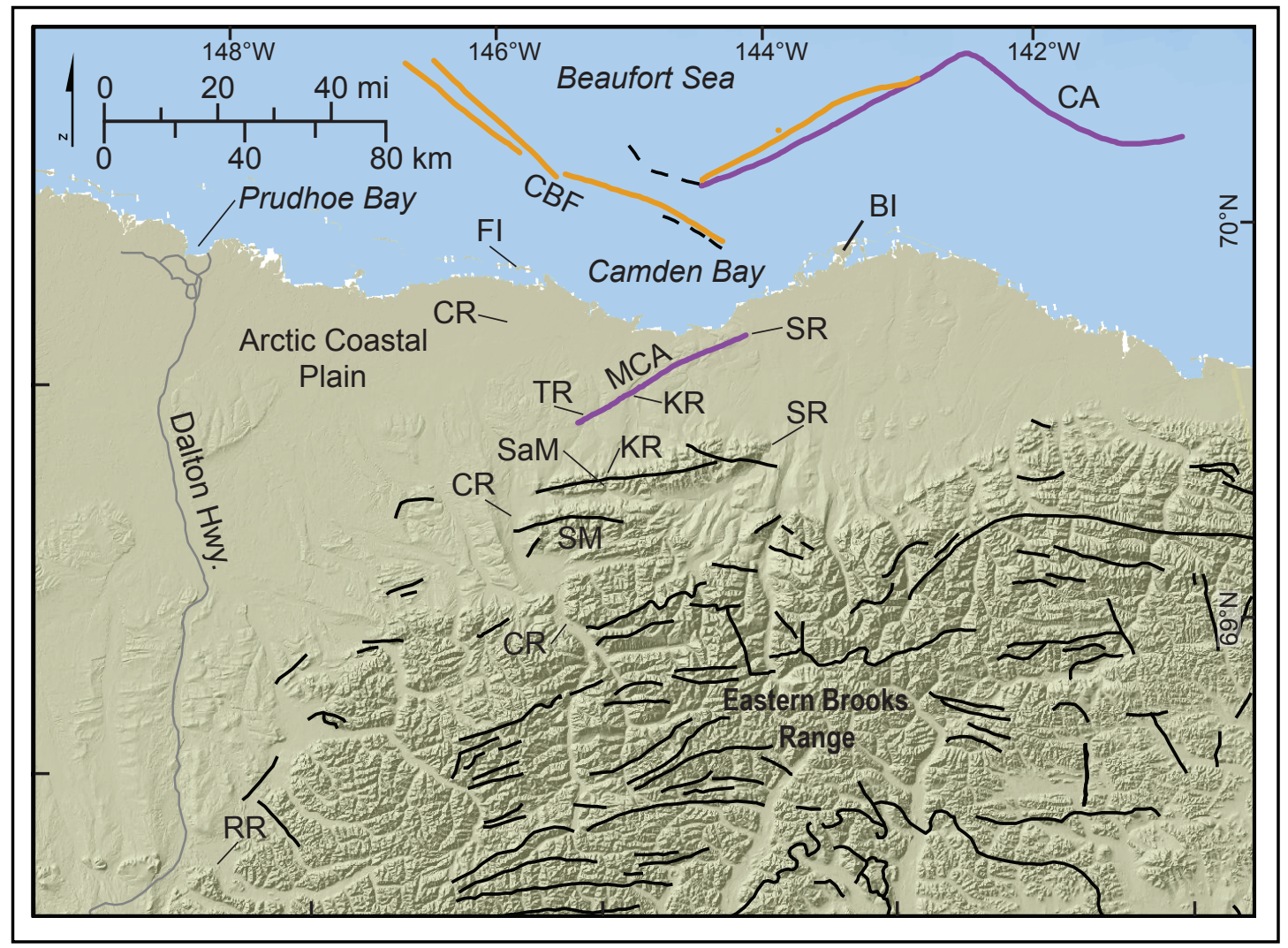

Figure 18. Map of the eastern part of the Northern Alaska and Brooks Range source region including the eastern Brooks Range and Arctic Coastal Plain. Map shows known active and potentially active Quaternary faults. Fault colors indicate relative age from Koehler (2013); see figure 2 for definitions. MCA = March Creek anticline, CBF = Camden Bay faults, $\mathrm{CA}=$ Camden anticline, $\mathrm{FI}=$ Flaxman Island, $\mathrm{BI}=$ Barter Island, SaM = Saddlerochit Mountains, $\mathrm{SM}=$ Shublik Mountains, $\mathrm{SR}=$ Saddlerochit River, $\mathrm{CR}=$ Canning River, $\mathrm{RR}=$ Ribdon River, $\mathrm{TR}=$ Tamayariak River.

moderate earthquakes $-\mathrm{M} 4$ in 1989 (AEC, 2016) and four moderate events in October 1980 (Gedney and Marshall, 1981), suggest that this region may be capable of generating a larger earthquake. No major or great earthquakes have been recorded in northern Alaska. Even with this seismic activity, only the Kobuk fault along the south side of the Brooks Range northwest of Bettles, faults in the Camden Bay area, and the Marsh Creek anticline have been inferred to be active in the Quaternary Period (Plafker and others, 1994a) (figs 11 and 18). Despite the apparent paucity of active faults, many pre-Quaternary faults have been mapped in the Brooks Range (Mull and others, 2009; Lathram, 1965; Grybeck and others, 1977; Imm and others, 1993; Mull and Adams, 1989) and represent zones of crustal weakness that could be reactivated in future earthquakes.
The Kobuk fault zone (fig. 11) extends along the northern border of the Upper Koyukuk basin and the southern margin of the Brooks Range for at least 480 $\mathrm{km}$ (300 mi). The fault zone consists of numerous high-angle parallel faults in a zone approximately $20 \mathrm{~km}$ (12.4 mi) wide (Patton, 1973). Bedding and structural contrasts across the fault support strike-slip deformation along the Kobuk fault in Cretaceous or Tertiary time (Patton, 1973); however, estimates of cumulative offset have not been determined. Kinematic analyses indicate lateral displacements as well as northward-directed thrusting along the Kobuk fault system related to right oblique plate convergence (Avé Lallemant and others, 1998). Patton and others (1968) and Patton and Miller (1966) map the fault in undifferentiated glacial deposits south of the Angayucham Mountains in the upper Kobuk and Alatna 
River valleys but did not describe details of the faulting (fig. 11). From the Alatna River to the vicinity of Bettles, Patton and Miller (1973) map the fault along the southern rangefront of the Alatna Hills. Brogan and others (1975) noted stream deflections and en echelon scarplets suggesting dextral slip along traces of the Kobuk fault mapped by Patton and others (1968) and described north- and south-facing scarps ranging from 1 to $12 \mathrm{~m}(3.3$ to $39 \mathrm{ft})$ in Illinoian and Wisconsin age glacial deposits. Hamilton (2002a) mapped the fault trace shown on Patton and Miller (1973) across outwash and drift of the early Pleistocene Anaktuvuk glaciation near the east and west forks of Henshaw Creek and inferred that the traces might be reactivated traces of the Kobuk fault. Farther west, in the upper Kobuk and Alatna River valleys, Hamilton (2002b) show the fault trace of Patton and Miller (1966) as cutting middle Pleistocene Sagavanirktok glacial drift and terraces, as well as late Wisconsin Itkillik drift, outwash, lake, and delta deposits. Along this section Hamilton (1984) described fault-related geomorphic features including elliptical pingos and sand extrusions, elongate sag and thaw ponds, fault scarps and fault-line scarps, uplifted lakeshores, and offset drainages, and suggested offsets of middle Pleistocene and late Wisconsin deposits of $20+\mathrm{m}(66+\mathrm{ft})$ and $2 \mathrm{~m}(6.6 \mathrm{ft})$, respectively. Unfortunately, the locations of the detailed Quaternary tectonic observations described by Hamilton (2002a, b) and Brogan and others (1975) have not been published or independently verified using modern paleoseismic techniques.

Reconnaissance helicopter inspection of the Kobuk fault along the Alatna Hills rangefront between Bettles and West Fork Henshaw Creek indicates the presence of isolated benches, broad troughs, and rounded knobs along the contact between Sagavanirktok glacial drift deposits and bed rock (fig. 19A). These features are not continuous, and direct evidence for a tectonic origin has not been verified. Erosion of ice-marginal stream channels and drift deposits are equally viable alternative explanations for the observed bench and trough morphology. The rangefront has a subdued morphology, with broad facets and curvilinear bedrock re-entrants floored by graded streams, consistent with either a very low slip rate or lack of Quaternary activity (fig. 19B). Directly west of West Fork Henshaw Creek, the northern margin of an Anaktuvuk drift deposit is interpreted by Hamilton (2002a) to be the trace of the Kobuk fault. Helicopter surveys of this feature indicate that it is an underfit curvilinear stream channel incised into the Anaktuvuk drift, more consistent with incision by an ice marginal stream (fig. 19C). Thus, despite the general lack of definitive evidence for Quaternary activity, the length of the Kobuk fault and a distinct cluster of seismicity along the western side and north of the fault (Gedney and Marshall, 1981) indicate that it might be capable of generating a large earthquake, and warrants further study. It is possible that rates of cryogenic processes could outpace and obscure evidence of tectonic activity due to the fault's low slip rate.

In the central Brooks Range, early to midTertiary orogenesis is supported by northward expansion of the orogenic wedge, folding of foreland basin deposits, apatite fission track data that indicates 4 to $6 \mathrm{~km}(2.5-3.7 \mathrm{mi})$ of exhumation since $70 \mathrm{Ma}$, and renewed exhumation in the core of the Brooks Range -24 Ma (Mull and others, 2009; Mull and others, 1997; O'Sullivan, 1994). Geologic and seismic studies indicate that deformation in the foothills fold-and-thrust belt propagated northward and was accommodated by east-northeast- and northeast-trending thrust faults and associated fault-propagation and fault-bend folds (O'Sullivan and others, 1998; Moore and others, 2004; Wallace, 2008a; Gillis and others, 2014). Diffuse low-level seismicity indicates that some of these structures could be capable of generating earthquakes; however, aerial reconnaissance of the Foothills fold-and-thrust belt along the Dalton Highway indicates that Quaternary glacial deposits are not deformed. 

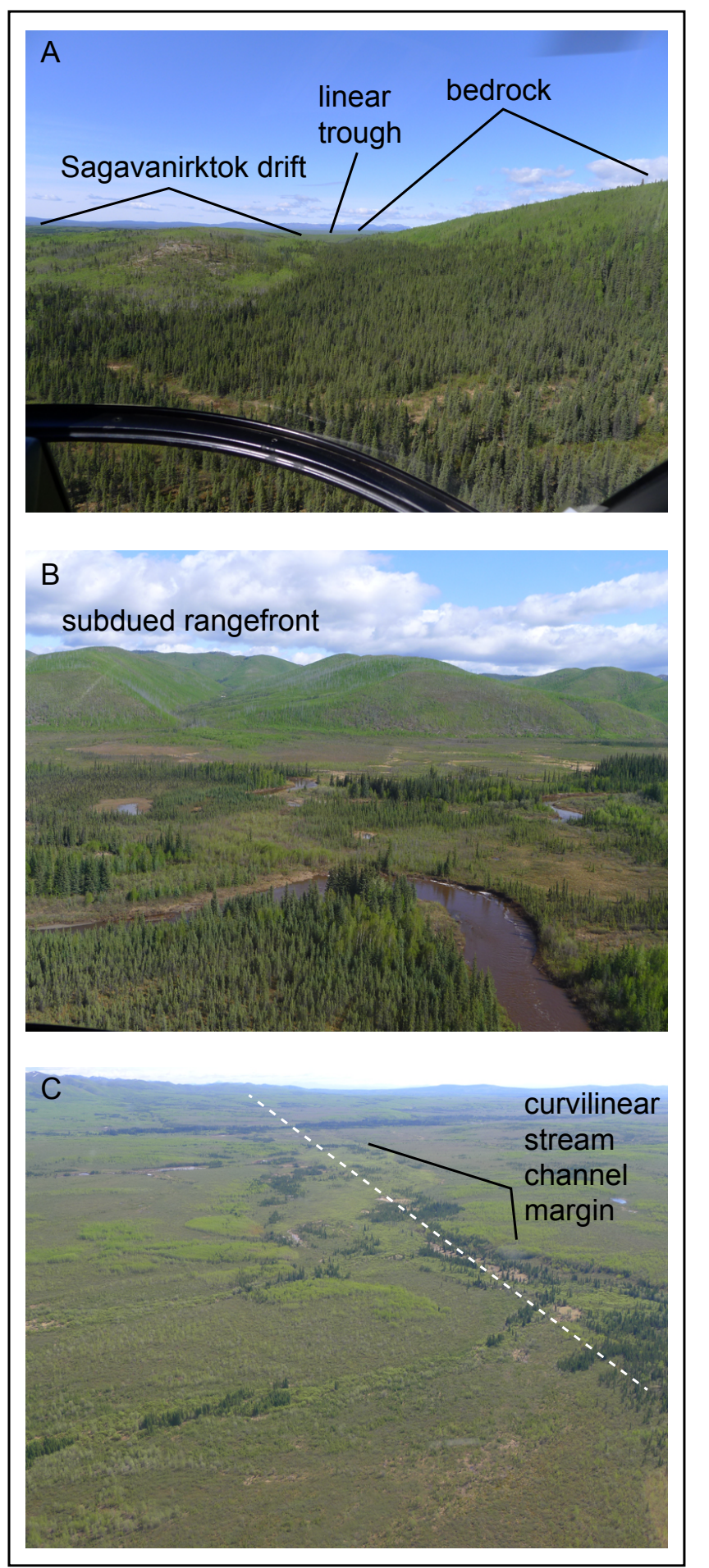

Figure 19. Photographs along the projection of the Kobuk fault. A. View, looking west, of knob and trough morphology along the Sagavanirktok drift-bedrock contact. Fault has been inferred to extend through subtle linear trough Hamilton (2002a; b). B. Subdued rangefront morphology along the Alatna Hills. C. View, looking east, along the mapped trace of the Kobuk fault (dotted white line), showing curvilinear stream channel margin formally described as a linear fault trace, but more likely an underfit ice marginal stream channel.
The northeastern Brooks Range foothills are characterized by a northward-tapering orogenic wedge that consists of duplexes and fault-bend folds and thrusts, hanging wall anticlines, and backthrusts that deform Tertiary rocks (Wallace, 2008a; Wallace and Hanks, 1990). East-northeast-trending faults and folds characterize the eastern Brooks Range mountain front between the Ribdon and Canning rivers, where and east-west-oriented structures become more prominent farther northeast in the Shublik and Sadlerochit Mountains (fig. 18). Fission track thermochronology data suggest the occurrence of three distinct Tertiary deformation events at 45, 35, and $27 \mathrm{Ma}$ (O'Sullivan and Wallace, 2002). North-directed shortening has apparently reactivated parts of the eastern Brooks Range foothills consistent with stratigraphic, seismic, and sparse geomorphic observations. Based on geologic mapping (Meigs, 1990) and interpretation of patterns in deflected, defeated, and antecedent streams, Burbank and others (1996) suggested ongoing growth of the Sadlerochit anticline. These observations include a deeply incised water gap occupied by the Katakturuk River, which extends across the narrow, western part of the range and the deflection of the Sadlerochit River around the nose of the range (Burbank and others, 1996) (fig. 18).

North of the Brooks Range, the Arctic Coastal Plain is relatively devoid of seismicity with the exception of the area east of the Canning River, north of the eastern Brooks Range foothills. Potential earthquake sources in this area include the Marsh Creek anticline, Camden anticline, Camden Bay faults, and other poorly documented structures (fig. 18). The northeast-plunging Marsh Creek anticline extends between the Tamayariak and Sadlerochit rivers on the eastern Arctic Coastal Plain above the reactivated convergent foreland fold-and-thrust belt. Steep dips of Pliocene beds and warped Pleistocene fluvial terraces across the anticline, as well as geomorphic observations that indicate that the Katakturuk River and Marsh Creek have been deflected along the 
margin of the anticline and cut across its crest, suggest active Quaternary and possibly younger growth of the anticline (Burbank and others, 1996; Bader and Bird, 1986; Kelley and Foland, 1987; Dinter and others, 1990; Grantz and others, 1983; Morris, 1957). The rates of folding and seismic potential of the Marsh Creek anticline have not been evaluated.

The Camden Bay anticline and faults occur primarily offshore in the Beaufort Sea and generally parallel the coast in the vicinity of Camden Bay and Flaxman Island (fig. 18). Based on interpretation of seismic reflection profiles, Grantz and others (1983) identified multiple active structures associated with the zone including deep-reaching landslides and related listric normal faults; aseismic normal faults and monoclines; and seismogenic, broad folds, monoclines, and faults. Deformation along these structures is primarily related to gravitational normal stresses generated by thick accumulations of Jurassic to present sediments shed off the Brooks Range and deposited on the continental shelf, and associated diapiric folding analogous to processes along the coast of Louisiana in the Gulf of Mexico. Additionally, contractional stresses associated with the foreland fold-and-thrust belt could contribute to active deformation offshore. A cluster of epicenters near the crest of the Camden anticline suggests modern activity, possibly related to a thrust splay inferred to core the anticline (Dinter and others, 1990). Activity on normal faults parallel to the crest of the Camden anticline has offset late Wisconsin- and Sangamonaged deposits 6 and $12 \mathrm{~m}$ (20 and $39 \mathrm{ft}$ ), respectively (Grantz and others, 1983). A moderate earthquake (M 5.3) occurred along the zone near Barter Island in 1968 (Biswas and others, 1977). A number of subsidiary folds have been mapped onshore in fluvial and glacial deposits (Carter and others, 1986); however, paleoseismic studies have not been conducted and their seismic potential and associated lateral spread hazards have not been evaluated. Although the rates of seismicity are low and surficial evidence of active tectonism are subtle, the structures on the
Arctic Coastal Plain might be capable of future moderate earthquakes.

\section{PLATE BOUNDARY STRAIN BUDGET AND ACTIVE FAULTS}

Plate boundary deformation associated with subduction along the Alaska-Aleutian subduction zone is distributed over $1,000 \mathrm{~km}(620 \mathrm{mi})$ from south-central Alaska to north of the Brooks Range. This deformation is accommodated along active faults by shortening, transpression, right-lateral strike-slip faulting, and crustal block rotations in southern and south-central Alaska, and transtensional left-lateral strike-slip faulting north of the Alaska Range in interior Alaska. The mechanisms of strain accommodation in the Brooks Range and northwestern Alaska are not as well understood but include clockwise rotation of the Bering microplate, right-lateral strike-slip deformation, reactivation of fold-and-thrust belt structures due to compression between North America and the Amerasian Basin, and gravitational listric faulting of thick sedimentary packages on the continental slope of the Beaufort Sea.

Geologic, geodetic, and paleoseismic studies in southern and south-central Alaska indicate that plate boundary-related shortening and transpression are accommodated by active faults in the Chugach-St. Elias Mountains (37 mm/yr [1.5 in/yr]), the Castle Mountain fault $(0.5 \mathrm{~mm} / \mathrm{yr}[0.02 \mathrm{in} / \mathrm{yr}])$, the Denali fault (7-14 mm/yr [0.3-0.6 in/yr]), and the Northern Foothills fold-and-thrust belt $(1.2-3.5 \mathrm{~mm} / \mathrm{yr}$ [0.05- $0.14 \mathrm{in} / \mathrm{yr}]$ ). Additionally, the system of faults that bounds the southern side of the Alaska Range (informally named the southern foothills fold-andthrust belt) likely accommodates a component of shortening. Given the orientation of these faults, the high, rugged topography, and the seismic and geologic evidence for active tectonism, we speculate that a reasonable shortening rate for individual faults in the southern foothills fold-and-thrust belt may be on the order of $0.5-1 \mathrm{~mm} / \mathrm{yr}(0.02-0.04 \mathrm{in} / \mathrm{yr})$. Recurrence intervals of hundreds of years for many 
of the faults in south-central Alaska attest to their relatively high slip rates and high seismic hazard.

Geodetically measured shortening $(<3 \mathrm{~mm} /$ yr $[<0.1 \mathrm{in} / \mathrm{yr}])$ between the Alaska Range and the Brooks Range cannot be resolved onto individual faults. Geodetic estimates of the collective rate of strain accumulation across the system of northeaststriking seismic zones in the vicinity of Fairbanks is $<2 \mathrm{~mm} / \mathrm{yr}$ (<0.1 in/yr) (Fletcher, 2002). In northern Alaska, including the Brooks Range, rates of strain accumulation are below the threshold of current GPS networks but suggest that there could be as much as $1 \mathrm{~mm} / \mathrm{yr}(0.04 \mathrm{in} / \mathrm{yr})$ distributed across a broad region. We infer that the threshold of recognition of surface scarps in northern Alaska is around 0.5 $\mathrm{m}$. Given that the landscape south of the Brooks Range was refreshed during the latest Wisconsin glaciation, which culminated around $6.2-8.3 \mathrm{ky}$ ago (Pewé, 1975) and geologic observations of the lack of surface scarps along mapped faults within the Dalton Highway corridor and in the Fairbanks area (Koehler and others, 2017), we further infer that faults in Interior and northern Alaska are characterized by long interseismic intervals, perhaps thousands to tens of thousands of years, and slip rates on the order of 0.01 to $<0.1 \mathrm{~mm} / \mathrm{yr}(0.0004$ to $0.004 \mathrm{in} /$ yr). These speculative rates are consistent with the weak geomorphic expression of active faults such as the Tintina and Kaltag faults and the interior Alaska seismic zones. The low rates contribute toward large uncertainties regarding which faults in interior and northern Alaska are capable of large surface rupturing earthquakes.

Figure 20 summarizes the currently available geologic, paleoseismic, and geodetic data distributed across the state along a transect (A-A') oriented roughly parallel to the Pacific/North American plate convergence direction. The transect extends across the Yakutat Collision Zone, southcentral, Interior, and northern Alaska/Brooks Range source regions. A cumulative shortening rate can be derived from review of the literature summarized in this paper and is shown by the color gradient band along the transect (fig. 20A). Figure 20B is a plot of shortening rate vs distance that shows values associated with individual regions and faults used to calculate a cumulative shortening rate. Horizontal lines represent the distance over which the rate is inferred including green lines for geodetic data and blue lines for geologic data. Vertical blue lines indicate the uncertainty (where available) in the geologic rate estimates. The maximum and minimum cumulative shortening based on the available data is indicated by the light gray shadowing and our preferred cumulative shortening is shown by a dashed black line.

To determine the preferred cumulative shortening across the transect we make the following assumptions; (1) the Northern Alaska/Brooks Range region is relatively stable (rate of essentially zero); (2) the central Interior is slowly deforming at a rate $\ll 2 \mathrm{~mm} / \mathrm{yr}$ (preferred value of $1 \mathrm{~mm} / \mathrm{yr}$ ); (3) strain is distributed across the Alaska Range including 0.5 $\mathrm{mm} / \mathrm{yr}$ across the Southern Foothills fold-and-thrust belt, $10 \mathrm{~mm} / \mathrm{yr}$ across the Denali fault, and $1.4 \mathrm{~mm} /$ yr across the Northern Foothills fold-and-thrust belt based on summing late Quaternary displacement rates on the main faults in the belt; (4) approximately $0.5 \mathrm{~mm} / \mathrm{yr}$ of shortening is distributed across the Copper River basin based on eastward projection of the Castle Mountain fault; and (5) geodetically measured strain accumulation across the Chugach-St. Elias fold-and-thrust belt $(-37 \mathrm{~mm} / \mathrm{yr})$ is a reasonable proxy for shortening due to the difficulty in obtaining geologically-based Quaternary observations in this rugged region.

In general, the rate of shortening diminishes in a northerly direction across the state from the plate convergence rate of $-51 \mathrm{~mm} / \mathrm{yr}(-2.0 \mathrm{in} / \mathrm{yr})$ along the Yakutat collision zone to $<1 \mathrm{~mm} / \mathrm{yr}(<0.04 \mathrm{in} / \mathrm{yr}$ ) in northern Alaska. Taken together, the combined geologic, paleoseismic, and geodetic observations compiled in this paper result in a cumulative shortening rate between 15.8 and $58 \mathrm{~mm} / \mathrm{yr}$, with a preferred rate of $50.4 \mathrm{~mm} / \mathrm{yr}$ (figs $20 \mathrm{~A}$ and 20B). The lower 


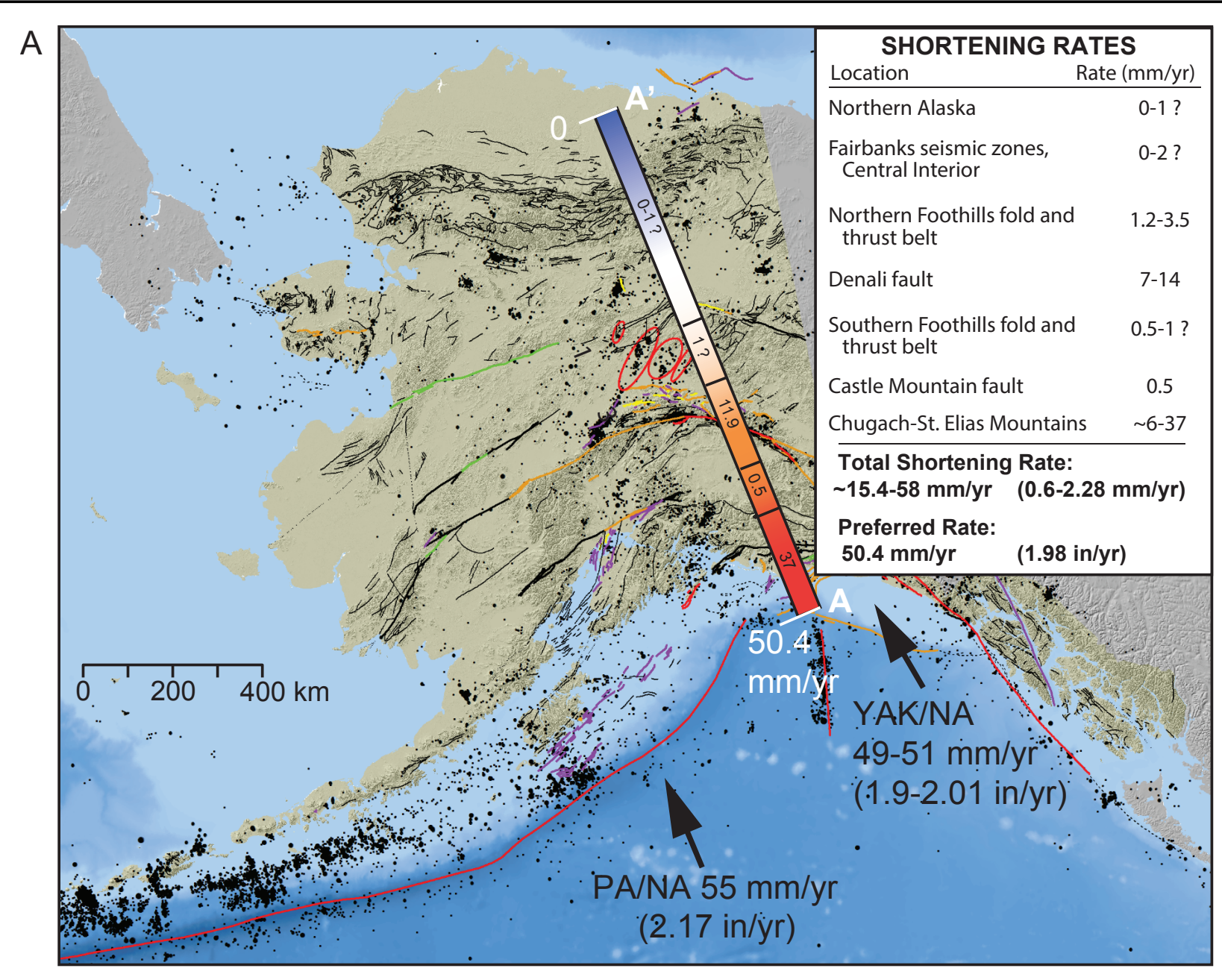

B

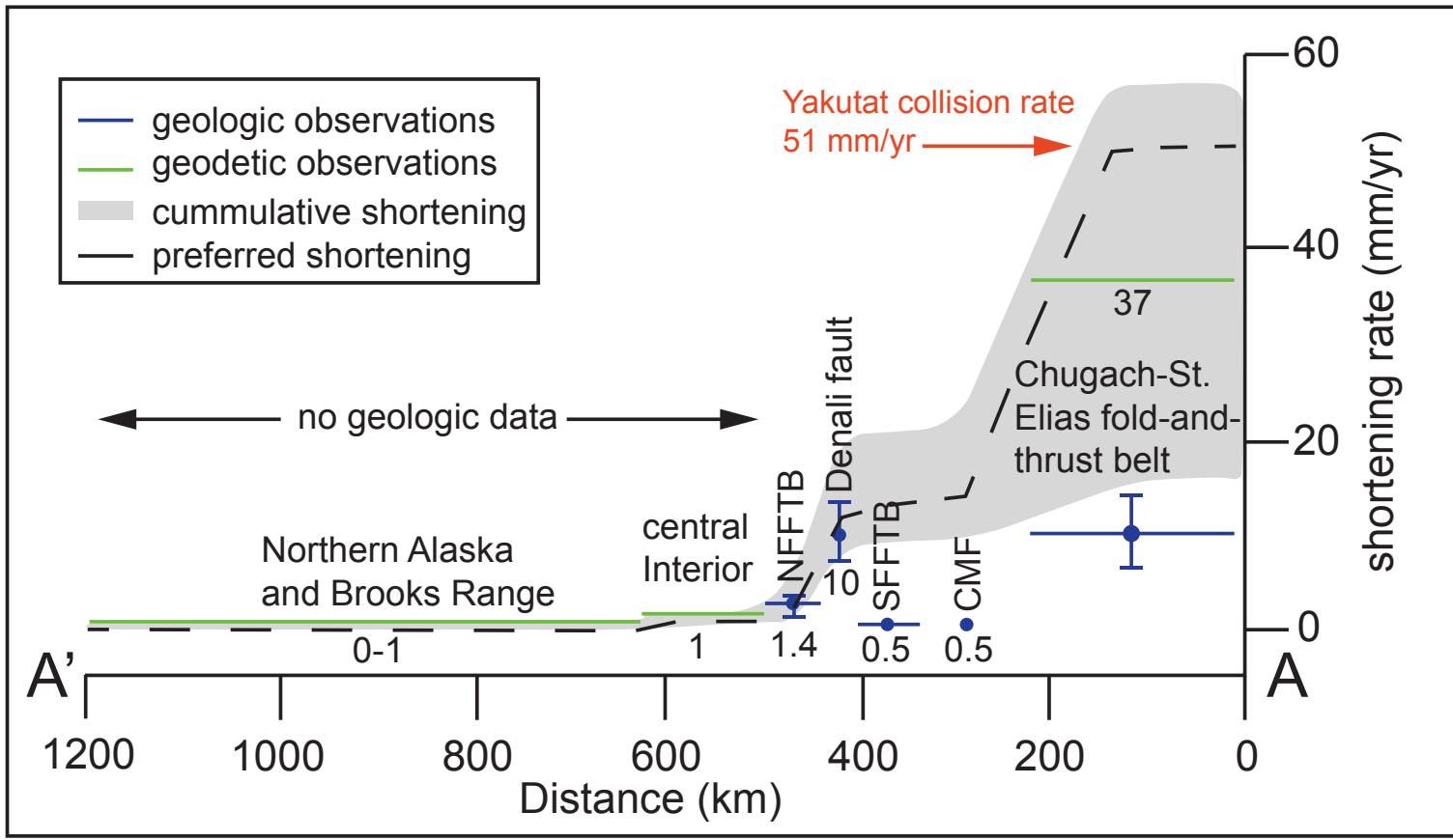


bound on the shortening rate range is likely related to under-characterized late Quaternary activity on faults in the Chugach-St. Elias fold-and-thrust belt and the higher bound may reflect overestimates of shortening in some areas. Certainly, the rate cannot be more than the plate convergence rate. The preferred rate, however, closely approximates the plate convergence rate, and indicates that the pattern of contemporary strain accumulation is consistent with the Quaternary pattern of strain release. This implies that the locations of the major seismic sources have been recognized and their relative activity has been moderately well-characterized at the reconnaissance level.

\section{CONCLUSIONS}

Alaska is one of most seismically active regions in the world and is exposed to seismic hazards related to frequent large earthquakes. Information on the location, size, timing, and recurrence of large earthquakes is an essential component of mitigating seismic risk. This paper summarizes the existing state of knowledge of the distribution of active faults and geologic and paleoseismic data with respect to the relative activity of structures capable of generating damaging earthquakes.

The quality and quantity of pertinent data needed for seismic hazard assessment is variable across the state. The best characterized regions include the Alaska-Aleutian subduction zone and Alaska Peninsula, the Benioff zone, the Queen CharlotteFairweather fault and southeastern Alaska, Yakutat microplate collision zone, and south-central Alaska source regions. Although the seismicity and location of active structures in interior Alaska are moderately well described, the timing and recurrence of earthquakes remain poorly characterized. Limited data are available to characterize active faults and evaluate the seismic potential of faults in the western Alaska and Bering Sea and northern Alaska and Brooks Range source regions.

The geologic record of youthful, surface-rupturing earthquakes throughout Alaska is likely obscured by high rates of latest Pleistocene loess deposition, cryogenic processes, thick forest cover, and rapid vegetation growth (tussocks) in tundra areas. The geologic evidence is also likely obscured and/or removed in many areas due to vigorous geomorphic processes such as landslides, flooding, and other events related to extreme climatic conditions. Factors such as difficult access, rugged topography, and the relatively few investigators conducting research in Alaska also contribute to the sparse amount of geologic observations. Thus, the lack of geologic evidence for major earthquakes does not preclude the possibility of future large magnitude events occurring anywhere in the state.

Although large uncertainties exist related to the timing and recurrence of large earthquakes and slip rates along active faults in Alaska, the sum of shortening observations related to active faults across the state is a close proxy to the rate of strain accumulation, suggesting that the majority of the major active faults have been recognized and characterized at a reconnaissance level. Active faults certainly exist that

Figure 20, opposite. A. Quaternary fault map of Alaska (Koehler, 2013) and plot of combined geologic, paleoseismic, and geodetic shortening observations. Color bar shows cumulative shortening rate along a transect oriented parallel to the Pacific/North American plate conver-gence direction. Color bar shows preferred values for each region used in calculating cumulative shortening. B. Plot of geologically- (blue lines) and geodetically-determined (green lines) rates of deformation from specific regions and faults (Meigs and others, 2008; Wallace 2008b, Elliot and others, 2013; Koehler and others, 2012b; 2013; Fletcher, 2002; Biggs and others, 2007; Matmon and others, 2006; Mériaux and others, 2009; Bemis and others, 2010; 2012; Freymueller, pers. comm.). Length of horizontal lines indicate the geographic distance over which each rate is evaluated. Light gray shading bounds the maximum and minimum cumulative shortening rate across the transect based on the published literature. Black dashed line indicates the preferred cumulative shortening rate. Values used to calcu-late the preferred cumulative shortening are listed below each region/fault. The combined observations indicate that, to first order, the pattern of strain accumulation is consistent with the relative activity and mapped locations of active faults. NFFTB, Northern Foothills fold-and-thrust belt; SFFTB, Southern Foothills fold-and-thrust belt; CMF, Castle Mountain fault. 
have not yet been mapped or have not produced a significant earthquake in historic time. Characterization of these faults as well as more detailed paleoseismic investigations along previously identified faults is necessary to better characterize the seismic hazard in the state.

\section{ACKNOWLEDGMENTS}

The concept for this paper was originally proposed by the Alaska Seismic Hazards Safety Commission (ASHSC) as a means to compile paleoseismic information on active faults throughout Alaska. The first author wishes to thank the commission for its patience during the data compilation phase and for encouragement to pursue its completion. Assimilating active tectonic research distributed across such a large tectonically diverse state is a daunting endeavor and would not be possible without relying on prior experiences, knowledge, and unwritten observations transmitted through informal discussions with many individuals who have conducted or are presently involved with on-going paleoseismologic, seismological, and geodetic research in the State. Although these individuals are too numerous to list we are grateful for fruitful discussions with George Plafker, Rob Witter, Rich Briggs, Simon Engelhart, Rod Combellick, Sean Bemis, Bob Swenson, David Schwartz, Rodger
Hanson, Jeff Freymueller, Jeff Benowitz, Gabriel Wolken, Patty Burns, Marwan Wartes, Bob Gillis, Trystan Herriott, Mike West, Paul Betka, and Julie Elliott, among others. It is their feedback through the course of this writing that helped focus our efforts and highlight our intended purpose: to provide a document to promote future research aimed at improving the understanding of seismic hazards in Alaska. The authors take sole responsibility for any individuals and/or research overlooked during our compilation.

Several observations from unpublished Division of Geological \& Geophysical Surveys (DGGS) reconnaissance field surveys conducted between 2009 and 2015 are incorporated into this report. We extend thanks to individuals who participated in field reconnaissance surveys for other DGGS projects, from which some of the observations presented in this paper were originally gathered and discussed. These individuals include Richard D. Reger, Rebecca-Ellen Farrell Woods, Ken Woods, Rachel Frohman, Alex Gould, Trent Hubbard, and Eleanor Spangler. Staff from the Alaska Earthquake Center including Roger Hansen, Natasha Ruppert, and Elizabeth Veenstra provided information on seismicity in each region. Insightful reviews from Peter Haeussler, Carl Tape, Mike West, Buzz Scher, and Barrett Salisbury are greatly appreciated. 


\section{REFERENCES}

Abrahamson, N.A., 2006, Seismic hazard assessmentProblems with current practice and future developments, in Proceedings, First European Conference on Earthquake Engineering and Seismology: Geneva Switzerland, European Association of Earthquake Engineering (EAEE), 17 p. http://www.preventionweb. net/files/1490_abstractsbook.pdf

Alaska Earthquake Center (AEC), 2016, University of Alaska Fairbanks: Website, last accessed 12-26-16. http://earthquake.alaska.edu/

Alaska, State of, 2013, Alaska State Hazard Mitigation Plan 2013: Alaska Department of Military and Veterans Affairs, Division of Homeland Security \& Emergency Management, 569 p. https://ready. alaska.gov/plans/mitigationplan

Avé Lallemant, H.G., Gottschalk, R.R., Sisson, V.B., and Oldow, J.S., 1998, Structural analysis of the Kobuk fault zone, north-central Alaska, in Oldow, J.S. and Avé Lallemant, H.G., eds., 1998, Architecture of the central Brooks Range fold and thrust belt, Arctic Alaska: Boulder, CO, Geological Society of America Special Paper 324, p. 261-268. http://doi.org/10.1130/0-8137-2324-8.261

Bader, J.W., and Bird, K.J., 1986, Geologic map of the Demarcation Point, Mt. Michelson, Flaxman Island, and Barter Island quadrangles, northeastern Alaska: U.S. Geological Survey Map I-1791, 1 sheet. http://ngmdb.usgs.gov/Prodesc/ proddesc_9911.htm

Barnes, F.F., 1962, Geologic map of lower Matanuska Valley, Alaska: U.S. Geological Survey Miscellaneous Geologic Investigations Map 359, 1 sheet, scale 1:63,360.

Beck, S.L., and Christensen, D.H., 1991, Rupture process of the February 4, 1965, Rat Islands earthquake: Journal of Geophysical Research, v. 96, no. B2, p. 2,205-2,221. http://doi. org/10.1029/90JB02092

Bemis, S.P., 2004, Neotectonic framework of the north-central Brooks Range foothills: Fairbanks, AK, University of Alaska Fairbanks, M.S. thesis, 142 p. Bemis, S.P., 2010, Moletrack scarps to mountainsQuaternary tectonics of the central Alaska Range: Eugene, OR, University of Oregon, Ph.D. dissertation, $121 \mathrm{p}$.
Bemis, S.P., Carver, G.A., and Koehler, R.D., 2012, The Quaternary thrust system of the northern Alaska Range: Geosphere, v. 8, no. 1, p. 1-10, 6 figs., 1 table. http//doi.org/10.1130/GES00695.1 Bemis, S.P., and Wallace, W.K., 2007, Neotectonic framework of the north-central Alaska Range foothills, in Ridgway, K.D., Trop, J.M., Glen, J.M.G., and O'Neill, J.M., eds., Tectonic Growth of a Collisional Continental Margin-Crustal Evolution of Southern Alaska: Geological Society of America Special Paper, v. 431, p. 549-572. http://doi.org/10.1130/2007.2431(21)

Bemis, S.P., Weldon, R.J., and Carver, G.A., 2015, Slip partitioning along a continuously curved fault-Quaternary geologic controls on Denali fault system slip partitioning, growth of the Alaska Range, and the tectonics of south-central Alaska: Lithosphere, v. 7, p. 235-246. http://doi.org/10.1130/L352.1

Berger, A.L., Spotila, J.A., Chapman, J.B., Pavlis, T.L., Enkelmann, Eva, Ruppert, N.A., and Buscher, J.T., 2008, Architecture, kinematics, and exhumation of a convergent orogenic wedge-A thermochronological investigation of tectonicclimatic interactions within the central St. Elias orogen, Alaska: Earth and Planetary Science Letters, v. 270, no. 1-2, p. 13-24. http://doi. org/10.1016/j.epsl.2008.02.034

Betka, P.M., and Gillis, R.J., 2014, Preliminary characterization of brittle deformation on the Iniskin Peninsula: Implications for the kinematic history of the Bruin Bay fault system, lower Cook Inlet, Alaska: Alaska Division of Geological \& Geophysical Surveys Preliminary Interpretive Report 2014-5, 14 p. http://doi. org/10.14509/29130

Biggs, Juliet, Wright, Tim, Lu, Zhong, and Parsons, Barry, 2007, Multi-interferogram method for measuring interseismic deformation-Denali fault, Alaska: Geophysical Journal International, v. 170, no. 3, p. 1,165-1,179. http://doi.org/10.1111/ j.1365-246X.2007.03415.x

Biswas, N.N., Gedney, L.D., and Huang, P., eds., 1977, Seismicity studies in northeast Alaska by a localized seismographic network: Geophysical Institute, University of Alaska Report 241, 22 p. 
Biswas, N.N., Pujol, J., Tytgat, Guy, and Dean, K., 1986, Synthesis of seismicity studies for western Alaska: Tectonophysics, v. 131, no. 3-4, p. 369-392. http://doi.org/10.1016/0040-1951(86)90183-6

Boss, R.F., Lennon, R.B., and Wilson, B.W., 1976, Middle Ground Shoal oil field, Alaska, in Braunstein, Jules, ed., North American oil and gas fields: American Association of Petroleum Geologists Memoir 24, p. 1-22.

Boyd, T.M., and Nabelek, J.L., 1988, Rupture process of the Andreanof Islands earthquake of May 7, 1986: Bulletin of the Seismological Society of America, v. 78, no. 5, p. 1,653-1,673.

Brabb, E.E., and Churkin, Michael, Jr., 1969, Geologic map of the Charley River Quadrangle, east-central Alaska, U.S. Geological Survey Miscellaneous Geologic Investigations Map 573, 1 sheet, scale 1:250,000. http://ngmdb.usgs.gov/ Prodesc/proddesc_9359.htm

Bramhall, E.H., 1938, The central Alaskan earthquake of July 22, 1937: Bulletin of the Seismological Society of America, v. 28, p. 71-75.

Briggs, R.W., Engelhart, S.E., Nelson, A.R., Dura, Tina, Kemp, A.C., Haeussler, P.J., Reide Corbett, D., Angster, S.J., and Bradley, L.A., 2014a, Uplift and subsidence reveal a non-persistent megathrust rupture boundary (Sitkinak Island, Alaska): Geophysical Research Letters, v. 41, no. 7, p. 2,2892,296. http://doi.org/10.1002/2014GL059380

Briggs, R.W., Witter, R.C., Nelson, A.R., Koehler, R.D., Haeussler, P.J., Engelhart, S.E., Gelfenbaum, G., Dura, Tina, and Carver, G.A., 2014b, Implications of recent paleoseismic observations for models of Alaska-Aleutian megathrust rupture patterns [abs.], Seismological Society of America 2014 Annual Meeting, Anchorage, AK, April 30May 2, 2014: Seismological Research Letters, v. 85, no. 2, p. 474. http//doi.org/10.1785/0220140014

Brogan, G.E., Cluff, L.S., Korringa, M.K., and Slemmons, D.B., 1975, Active faults of Alaska: Tectonophysics, v. 29, no. 1-4, p. 73-85. http// doi.org/10.1016/0040-1951(75)90134-1

Bruhn, R.L., 1979, Holocene displacements measured by trenching the Castle Mountain fault near Houston, Alaska, in Short Notes on Alaskan Geology, 1978: Alaska Division of Geological \&
Geophysical Surveys Geologic Report 61, p. 1-4. http://doi.org/10.14509/408

Bruhn, R.L., and Haeussler, P.J., 2006, Deformation driven by subduction and microplate collisionGeodynamics of Cook Inlet basin, Alaska: Geological Society of America Bulletin, v. 118, no. 3-4, p. 289-303. http://doi.org/10.1130/B25672.1

Bruhn, R.L., Pavlis, T.L., Plafker, George, and Serpa, Laura, 2004, Deformation during terrane accretion in the Saint Elias orogen, Alaska: Geological Society of America Bulletin, v. 116, no. 7-8, p. 771-787. http://doi.org/10.1130/B25182.1

Bundtzen, T.K., Laird, G.M., and Lockwood, M.S., 1988, Geologic map of the Iditarod C-3 Quadrangle, Alaska: Alaska Division of Geological \& Geophysical Surveys Professional Report 96, 13 p., 1 sheet, scale 1:63,360. http://doi. org/10.14509/2277

Burbank, Douglas, Meigs, Andrew, and Brozović, Nicholas, 1996, Interactions of growing folds and coeval depositional systems: Basin Research, v. 8, no. 3, p. 199-223. http://doi.org/10.1046/j.13652117.1996.00181.x

Cady, W.M., Wallace, R.E., Hoare, J.M., and Webber, E.J., 1955, The central Kuskokwim region, Alaska: U.S. Geological Survey Professional Paper 268, $132 \mathrm{p}$.

Carlson, J.K., Bemis, S., Toke, N., Bishop, B., and Taylor, T.P., 2017, Documentation of seven earthquakes over the past -7000 years on the westcentral Denali fault at the Nenana River, Alaska, Bulletin of the Seismological Society of America, v. 108, No. 1, pp. 84-100. doi: 10.1785/0120170070 Carter, L.D., Ferrians, O.J., and Galloway, J.P., 1986, Engineering geologic maps of northern Alaska coastal plain and foothills of the Arctic National Wildlife Refuge: U.S. Geological Survey Open File Report 86-334, 9 p., 2 sheets (one sheet 1:250,000; 1 sheet text).

Carver, G.A., Bemis, S.P., Solie, D.N., and Obermiller, K.E., 2008a, Active and potentially active faults in or near the Alaska Highway corridor, Delta Junction to Dot Lake, Alaska: Alaska Division of Geological \& Geophysical Surveys Preliminary Interpretive Report 2008-3D, 32 p. http://doi. org/10.14509/17901 
Carver, G.A., Bemis, S.P., Solie, D.N., Castonguay, S., and Obermiller, K.E., 2010, Active and potentially active faults in or near the Alaska Highway corridor, Dot Lake to Tetlin Junction, Alaska: Alaska Division of Geological \& Geophysical Surveys Preliminary Interpretive Report 2010-1, 42 p. http://doi.org/10.14509/21121

Carver, Gary, and Plafker, George, 2008, Paleoseismicity and neotectonics of the Aleutian subduction zone-An overview, in Freymueller, J.T., Haeussler, P.J., Wesson, R.L., and Ekström, G., eds., Active Tectonics and Seismic Potential of Alaska: American Geophysical Union Geophysical Monograph Series, v. 179, p. 43-63. http://doi.org/10.1029/179GM03 Carver, Gary, Plafker, George, Metz, Mike, Cluff, Lloyd, Slemmons, Burt, Johnson, Elden, Roddick, Jim, and Sorensen, Steve, 2004, Surface rupture on the Denali fault interpreted from tree damage during the 1912 Delta River Mw 7.2-7.4 earthquake-Implications for the 2002 Denali fault earthquake slip distribution, in Rowe, C.A., Christensen, D., and Carver, G., eds., The 2002 Denali fault earthquake sequence: Bulletin of the Seismological Society of America, v. 94, no. 6B, p. S58-S71. http://doi.org/10.1785/0120040625 Carver, Gary, Sauber, J., Lettis, W., Witter, R.L., and Whitney, B., 2008b, Active faults on northeastern Kodiak Island, Alaska, in Freymueller, J.T., Haeussler, P.J., Wesson, R.L., and Ekström, G., eds., Active Tectonics and Seismic Potential of Alaska: American Geophysical Union Geophysical Monograph Series, v. 179, p. 167-184. http://doi. org/10.1029/179GM09

Chapman, J.B., Pavlis, T.L., Gulick, S.P.S., Berger, A.L., Lowe, Lindsay, Spotila, James, Bruhn, R.L., Vorkink, Michael, Koons, Peter, Barker, Adam, Picornell, Carlos, Ridgway, Ken, Hallet, Bernard, Jaeger, John, and McCalpin, James, 2008, Neotectonics of the Yakutat collision-Changes in deformation driven by mass redistribution, in Freymueller, J.T., Haeussler, P.J., Wesson, R.L., and Ekström, G., eds., Active Tectonics and Seismic Potential of Alaska: American Geophysical Union Geophysical Monograph Series, v. 179, p. 65-81. http://doi.org/10.1029/179GM04

Chapman, J.B., Pavlis, T.L., Bruhn, R.L., Worthington,
L.L., Gulick, S.P.S., and Berger, A.L., 2012, Structural relationships in the eastern syntaxis of the St. Elias orogen, Alaska: Geosphere, v. 8, no. 1, p. 105-126. http://doi.org/10.1130/GES00677.1 Christensen, D.H., and Beck, S.L., 1994, The rupture process and tectonic implications of the great 1964 Prince William Sound earthquake: Pure and Applied Geophysics, v. 142, no. 1, p. 29-53. http:// doi.org/10.1007/BF00875967

Christeson, G.L., Gulick, S.P.S., van Avendonk, H.J.A., Worthington, L.L., Reece, R.S., and Pavlis, T.L., 2010, The Yakutat terrane-Dramatic change in crustal thickness across the Transition fault, Alaska: Geology, v. 38, no. 10, p. 895-898. http:// doi.org/10.1130/G31170.1

Cornell, C.A., 1968, Engineering seismic risk analysis: Bulletin of the Seismological Society of America, v. 58 , no. 5 , p. $1,583-1,606$.

Crone, A.J., Personius, S.F., Craw, P.A., Haeussler, P.J., and Staft, L.A., 2004, The Susitna Glacier thrust fault-Characteristics of surface ruptures on the fault that initiated the 2002 Denali fault earthquake, in Rowe, C.A., Christensen, D., and Carver, G., eds., The 2002 Denali fault earthquake sequence: Bulletin of the Seismological Society of America, v. 94, no. 6B, p. S5-S22. http://doi. org/10.1785/0120040619

Davies, J.N., 1972, Crustal morphology of central Alaska [abs.]: Geological Society of America Abstracts with Programs, v. 4, no. 3, Cordilleran Section, 68th Annual Meeting, p. 144-145.

Davies, J.N., 1975, Seismological interpretation of plate tectonics in south-central Alaska: Fairbanks, AK, University of Alaska Fairbanks, Ph.D. thesis, 193 p.

Davies, J.N., and House, Leigh, 1979, Aleutian subduction zone seismicity, volcano-trench separation, and their relation to great thrust-type earthquakes: Journal of Geophysical Research, v. 84, no. B9, p. 4,583-4,591. http://doi. org/10.1029/JB084iB09p04583

Davies, J.N., Sykes, L., House, Leigh, and Jacob, K., 1981, Shumagin seismic gap, Alaska PeninsulaHistory of great earthquakes, tectonic setting, and evidence for high seismic potential: Journal of Geophysical Research, v. 86, no. B5, p. 3,8213,855. http://doi.org/10.1029/JB086iB05p03821 
Davis, T.N., 1960, A field report on the Alaska earthquakes of April 7, 1958: Bulletin of the Seismological Society of America, v. 50, no. 4, p. 489-510.

Decker, J.E., Reifenstuhl, R.R., Robinson, M.S., Waythomas, C.F., and Clough, J.G., 1995, Geology of the Sleetmute A-5, A-6, B-5, and B-6 quadrangles, southwestern Alaska: Alaska Division of Geological \& Geophysical Surveys Professional Report 99, 16 p., 2 sheets. http://doi. org/10.14509/2280

DeMets, C., Gordon, R.G., Argus, D.F., and Stein, S., 1990, Current plate motions: Geophysical Journal International, v. 101, no. 2, p. 425-478. http://doi. org/10.1111/j.1365-246X.1990.tb06579.x

Detterman, R.L., and Hartsock, J.K., 1966, Geology of the Iniskin-Tuxedni region, Alaska: U.S. Geological Survey Professional Paper 512, 78 p., 6 sheets, scale 1:63,360.

Detterman, R.L., and Reed, B.L., 1980, Stratigraphy, structure, and economic geology of the Iliamna Quadrangle, Alaska: U.S. Geological Survey Bulletin 1368-B, p. B1-B86, 1 sheet, scale 1:250,000.

Detterman, R.L., Hudson, Travis, and Hoare, J.M., 1975, Bruin Bay fault inactive during the Holocene, in Yount, M.E., ed., U.S. Geological Survey Alaska Program, 1975, U.S. Geological Survey Circular 722, p. 44-45.

Detterman, R.L., Hudson, Travis, Plafker, George, Tysdal, R.G., and Hoare, J.M., 1976, Reconnaissance geologic map along the Bruin Bay and Lake Clark faults in Kenai and Tyonek quadrangles, Alaska: U.S. Geological Survey Open File Map 76-477, 4 p., scale: 1:250,000.

Detterman, R.L., Plafker, George, Hudson, Travis, Tysdal, R.G., Pavoni, Nazario, and Weber, F.R., 1974, Surface geology and Holocene breaks along the Susitna segment of the Castle Mountain Fault, Alaska: U.S. Geological Survey Miscellaneous Field Studies Map 618, 1 sheet, scale 1:24,000.

Devore, J.R., Bemis, S.P., and Walker, L.A., 2012, Evidence for post-26 ka displacement of the Northern Foothills Thrust at the Nenana River, Alaska (Abstract T11A-2552): American Geophyscal Union, 2012 Fall Meeting, San Francisco, CA, Dec. 3-7.
Dinter, D.A., Carter, L.D., and Brigham-Grette, Julie, 1990, Late Cenozoic geologic evolution of the Alaskan North Slope and adjacent continental shelves, in Grantz, Arthur, Johnson, L., and Sweeney, J.F., eds., The Arctic Ocean region/ The Geology of North America: Boulder, CO, Geological Society of America, v. L, p. 459-490.

Dixon, J.P., 1988, Seismicity of the 1985 Dall City earthquake sequence: Fairbanks, AK, University of Alaska Fairbanks, M.S. thesis.

Doser, D.I., 2004, Seismicity of the DenaliTotschunda fault zone in central Alaska (19121988) and its relation to the 2002 Denali fault earthquake sequence: Bulletin of the Seismological Society of America, v. 94, no. 6B, p. S132-S144. http://doi.org/10.1785/0120040611

Doser, D.I., and Brown, W.A, 2001, A study of historic earthquakes of the Prince William Sound, Alaska region: Bulletin of the Seismological Society of America, v. 91, no. 4, p. 842-857. http://doi. org/10.1785/0120000241

Dumitru, T.A., Miller, E.L., O’Sullivan, P.B., Amato, J.M., Hannula, K.A., Calvert, A.T., and Gans, P.B., 1995, Cretaceous to Recent extension in the Bering Strait region, Alaska: Tectonics, v. 14, no. 3, p. 549-563. http://doi.org/10.1029/95TC00206 Eberhart-Phillips, Donna, Haeussler, P.J., Freymueller, J.T., Frankel, A.D., Rubin, C.M., Craw, Patricia, Ratchkovski, N.A., Anderson, Greg, Carver, G.A., Crone, A.J., Dawson, T.E., Fletcher, Hilary, Hansen, Roger, Harp, E.L., Harris, R.A., Hill, D.P., Hreinsdóttir, Sigrún, Jibson, R.W., Jones, L.M., Kayen, Robert, Keefer, D.K., Larsen, C.F., Moran, S.C., Personius, S.F., Plafker, George, Sherrod, Brian, Sieh, Kerry, Sitar, Nicholas, and Wallace, W.K., 2003, The 2002 Denali fault earthquake, Alaska-A large magnitude, slip-partitioned event: Science, v. 300, no. 5622, p. 1,113-1,118. http// doi.org/10.1126/science.1082703

Elliott, J.L., Larsen, C.F., Freymueller, J.T., and Motyka, R.J., 2010, Tectonic block motion and glacial isostatic adjustment in southeast Alaska and adjacent Canada constrained by GPS measurements: Journal of Geophysical Research, v. 115, no. B9, B09407, 21 p. http://doi.org/10.1029/2009JB007139 
Elliott, J.L., Freymueller, J.T., and Larsen C.F., 2013, Active tectonics of the St. Elias orogeny, Alaska, observed with GPS measurements, Journal of Geophysical Research: Solid Earth, Vol. 118, 5625-5642. http://doi.org/10.1002/jgrb.50341

Estabrook, C.H., 1985, Seismotectonics of northern Alaska: Fairbanks, AK, University of Alaska Fairbanks, M.S. thesis, 139 p.

Fernald, A.T., 1960, Geomorphology of the upper Kuskokwim region, Alaska: U.S. Geological Survey Bulletin 1071-G, 88 p., 2 sheets, 1:250,000 scale. Field, E.H., Biasi, G.P., Bird, P., Dawson, T.E., Felzer, K.R., Jackson, D.D., Johnson, K.M., Jordan, T.H., Madden, C., Michael, A.J., Milner, K.R., Page, M.T., Parsons, T., Powers, P.M., Shaw, B.E., Thatcher, W.R., Weldon, R.J., II, and Zeng, Y., 2013, Uniform California earthquake rupture forecast, version 3 (UCERF3)-The time-independent model: U.S. Geological Survey Open-File Report 2013-1165, 97 p., California Geological Survey Special Report 228, and Southern California Earthquake Center Publication 1792. http://pubs.usgs.gov/of/2013/1165/

Field, E.H., Dawson, T.E., Felzer, K.R., Frankel, A.D., Gupta, V., Jordan, T.H., Parsons, T., Petersen, M.D., Stein R.S., Weldon II, R.J., Wills, C.J., 2009, Uniform California earthquake rupture forecast, version 2 (UCERF 2), Bulletin of the Seismological Society of America, v. 99, p. 2,0532,107. http://doi.org/10.1785/0120080049

Fletcher, H.J., 2002, Crustal deformation in Alaska measured using the Global Positioning System: Fairbanks, AK, University of Alaska Fairbanks Ph.D. thesis, 135 p.

Fletcher, H.J., and Freymueller, J.T., 2003, New constraints on the motion of the Fairweather fault, Alaska, from GPS observations: Geophysical Research Letters, v. 30, no. 3, 1139, 4 p. http:// doi.org/10.1029/2002GL016476

Foster, H.L., comp., 1976, Geologic map of the Eagle Quadrangle, Alaska: U.S. Geological Survey Miscellaneous Investigations Series Map 922, 1 sheet, scale 1:250,000.

Foster, H.L., Laird, Jo, Keith, T.E., Cushing, G.W., and Menzie, W.D., 1983, Preliminary geologic map of the Circle Quadrangle, Alaska: U.S.
Geological Survey Open-File Report 83-170-A, 30 p., 1 sheet, scale 1:250,000.

Frankel, A.D., Petersen, M.D., Mueller, C.S., Haller, K.M., Wheeler, R.L., Leyendecker, E.V., Wesson, R.L., Harmsen, S.C., Cramer, C.H., Perkins, D.M., and Rukstales, K.S., 2002, Documentation for the 2002 update of the National Seismic Hazard Maps: U.S. Geological Survey Open-File Report 2002-420, 33 p. https://pubs.usgs.gov/of/2002/ ofr-02-420/

Freymueller, J.T., Woodward, H., Cohen, S.C., Cross, R., Elliot, J., Larsen, C.F., Hreinsdóttir, S., and Zweck, C., 2008, Active deformation processes in Alaska, based on 15 years of GPS measurements, in Freymueller, J.T., Haeussler, P.J., Wesson, R.L., and Ekström, G., eds., Active Tectonics and Seismic Potential of Alaska: American Geophysical Union Geophysical Monograph Series 179, p. 1-42. http://doi.org/10.1029/179GM02

Fuchs, W.A., 1980, Tertiary tectonic history of the Castle Mountain fault-Caribou fault system in the Talkeetna Mountains, Alaska: Salt Lake City, UT, University of Utah, Ph.D. thesis, 152 p.

Fugro Consultants Inc., 2011, Seismic hazard characterization and ground motion analyses for Susitna-Watana dam site, NTP 6 Seismic Studies, Technical Memorandum No. 4, v0, AEA11-022. Gedney, Larry, and Berg, Eduard, 1969, The Fairbanks earthquakes of June 21, 1967-Aftershock distribution, focal mechanisms, and crustal parameters: Bulletin of the Seismological Society of America, v. 59, no. 1, p. 73-100.

Gedney, Larry, and Marshall, Dianne, 1981, A rare earthquake sequence in the Kobuk Trench, northwestern Alaska: Bulletin of the Seismological Society of America, v. 71, no. 5, p. 1,587-1,592.

Gedney, Larry, Berg, Eduard, Pulpan, Hans, Davies, J.N., and Feetham, William, 1969, A field report on the Rampart, Alaska earthquake of October 29, 1968: Bulletin of the Seismological Society of America, v. 59, no. 3, p. 1,421-1,423.

Gedney, Larry, Shapiro, L., and VanWormer, D., 1972, Correlation of epicenters with mapped faults, east-central Alaska, 1968-1971: U.S. Geological Survey Open-File Report 72-128, 7 p., 1 sheet, scale 1:1,000,000. 
Geomatrix Consultants, 1997, Final report-Sitespecific earthquake ground motion study for radar building site, Clear Air Force Station, Alaska: U.S. Army Engineer Division, Huntsville, AL, project number 3993.

Gillis, R.J., Decker, P.L., Wartes, M.A., Loveland, A.M., and Hubbard, T.D., 2014, Geologic map of the south-central Sagavanirktok Quadrangle, North Slope, Alaska: Alaska Division of Geological \& Geophysical Surveys Report of Investigation 2014-4, 24 p., 2 sheets, scale 1:63,360. http://doi. org/10.14509/29138

Grantz, Arthur, 1966, Strike-slip faults in Alaska: U.S. Geological Survey Open-File Report 267, 82 p.

Grantz, Arthur, Dinter, D.A., and Biswas, N.N., 1983, Map, cross sections, and chart showing late Quaternary faults, folds, and earthquake epicenters on the Alaskan Beaufort Shelf: U.S. Geological Survey Miscellaneous Investigations I-1182-C, scale 1:500,000, 7 p., 3 sheets, 1:500,000 scale.

Graves, Robert, Jordan, T.H., Callaghan, Scott, Deelman, Ewa, Field, Edward, Juve, Gideon, Kesselman, Carl, Maechling, Philip, Mehta, Gaurang, Milner, Kevin, Okaya, David, Small, Patrick, and Vahi, Karan, 2011, CyberShake: A physics-based seismic hazard model for southern California, Pure and Applied Geophysics, v. 168, p. 367-381. http://doi.org/10.1007/s00024-010$0161-6$

Greene, H.G., Barrie, J.V.J., Brothers, D.S., Nishenko, S.P., Conway, K., Enkin, R., Conrad, J.E., Maier, K.L., and Stacy, C., 2016, The Queen CharlotteFairweather fault zone - The knife edged PacificNorth American plate boundary [abs.]: Eos Transactions American Geophysical Union, Fall Meeting Supplement, Abstract OS12B-08.

Grybeck, Donald, Beikman, H.M., Brosgé, W.P., Tailleur, I.L., and Mull, C.G., 1977, Geologic map of the Brooks Range, Alaska: U.S. Geological Survey Open-File Report 77-166-B, 2 sheets, scale 1:1,000,000.

Gulick, S.P.S., Lowe, L.A., Pavlis, T.L., Gardner, J.V., and Mayer, L.A., 2007, Geophysical insights into the Transition fault debate-Propagating strike slip in response to stalling Yakutat block subduction in the Gulf of Alaska: Geology, v. 35, no. 8, p. 763-766. http://doi.org/10.1130/G23585A.1

Gulick, S.P.S., Reece, R.S., Christeson, G.L., van Avendonk, H., Worthington, L.L., and Pavlis, T.L., 2013, Seismic images of the Transition fault and the unstable Yakutat-Pacific-North American triple junction: Geology, v. 41, no. 5, p. 571-574. http://doi.org/10.1130/G33900.1

Haeussler, P.J., 2008, An overview of the neotectonics of interior Alaska-Far-field deformation from the Yakutat microplate collision, in Freymueller, J.T., Haeussler, P.J., Wesson, R.L., and Ekström, G., eds., Active Tectonics and Seismic Potential of Alaska: American Geophysical Union Geophysical Monograph Series, v. 179, p. 83-108. http://doi. org/10.1029/179GM05

Haeussler, P.J., and Plafker, G., 2004, Earthquakes in Alaska: U.S. Geological Survey Open-File Report 95-624.

Haeussler, P.J., and Saltus, R.W., 2005, 26 km of offset on the Lake Clark fault since late Eocene time, in Haeussler, P.J., and Galloway, J.P., eds., Studies by the U.S. Geological Survey in Alaska, 2004: U.S. Geological Survey Professional Paper 1709-A, 4 p. Haeussler, P.J., and Saltus, R.W., 2011, Location and extent of Tertiary structures in Cook Inlet basin, Alaska, and mantle dynamics that focus deformation and subsidence, in Dumoulin, J.A., and Galloway, J.P., eds., Studies by the U.S. Geological Survey in Alaska, 2008-2009: U.S. Geological Survey Professional Paper 1776-D, $26 \mathrm{p}$.

Haeussler, P.J., Best, T.C., and Waythomas, C.F., 2002, Paleoseismology at high latitudes_-Seismic disturbance of upper Quaternary deposits along the Castle Mountain fault near Houston, Alaska: Geological Society of America Bulletin, v. 114, no. 10, p. 1,296-1,310.

Haeussler, P.J., Bruhn, R.L., and Pratt, T.L., 2000, Potential seismic hazards and tectonics of the upper Cook Inlet basin, Alaska, based on analysis of Pliocene and younger deformation: Geological Society of America Bulletin, v. 112, no. 9, p. 1,414-1,429. 
Haeussler, P.J., Matmon, A., Schwartz, D.P., Seitz, G., 2014, The Denali fault slip rate and models of interior Alaska active deformation [abs.]: Seismological Society of America Annual Meeting, Anchorage, Alaska, April 30-May 2, 2014, Abstracts with Programs, v. 85, no. 2, p. 474.

Haeussler, P.J., Schwartz, D.P., Dawson, T.E., Stenner, H.D., Lienkaemper, J.J., Sherrod, B., Cinti, F.R., Montone, P., Craw, P.A., Crone, A.J., and Personius, S.F., 2004, Surface rupture and slip distribution of the Denali and Totschunda faults in the 3 November 2002 M 7.9 earthquake, Alaska: Bulletin of the Seismological Society of America, v. 94, no. 6B, p. S23-S52.

Hamilton, T.D., 2002a, Surficial geologic map of the Bettles Quadrangle, Alaska: U.S. Geological Survey, Miscellaneous Field Studies Map MF2409, 9 p., 1 sheet.

Hamilton, T.D., 2002b, Surficial geologic map of the Hughes Quadrangle, Alaska: U.S. Geological Survey, Miscellaneous Field Studies Map MF2408, 10 p. 1 sheet.

Hamilton, T.D., 1984, Late Quaternary offsets along the Kobuk and related fault zones, northwestern Alaska: Geological Society of America Abstracts with Programs, v. 16, no. 5, p. 288.

Hanson, K.L., Wells, D.L., and Angell, M., 2002, Activity of the Northern Foothills thrust faultStrain partitioning related to the Denali fault, central Alaska [abs.]: Eos Transactions, American Geophysical Union, v. 83, no. 47, p. 1,333; abstract \#S72F-1333.

Hart, E.W., 1980, Fault-rupture hazard zones in California: California Division of Mines and Geology Special Publication 42, 25 p.

Hoare, J.M., 1961, Geology and tectonic setting of lower Kuskokwim-Bristol Bay region, Alaska: American Association of Petroleum Geologists Bulletin, v. 45, no. 5, p. 594-611.

Hoare, J.M., and Coonrad, W.L., 1961, Geologic map of the Goodnews Quadrangle, Alaska: U.S. Geological Survey Miscellaneous Geologic Investigations Map 339, 1 sheet, scale 1:250,000.

Hudson, Travis, and Plafker, George, 1978, Kigluaik and Bendeleben faults, Seward Peninsula, in Johnson, K.M., ed., The United States Geological
Survey in Alaska-Accomplishments during 1977: U.S. Geological Survey Circular 772-B, p. 47-50. Hudson, Travis, Plafker, George, and Dixon, K., 1982, Horizontal offset history of the Chatham Strait fault, in Coonrad, W.L, ed., The United States Geological Survey in Alaska-Accomplishments in 1980: U.S. Geological Survey Circular 844, p. 128-132.

Ichinose, G.P., Somerville, H.K., Thio, H.K., Graves, R., and O'Connell, D., 2007, Rupture process of the 1964 Prince William Sound, Alaska, earthquake from the combined inversion of seismic, tsunami, and geodetic data, Journal of Geophysical Research, vol. 112, B07306. http:// doi.org/10.1029/2006JB004728

Imm, T.A., Dillon, J.T., and Bakke, A.A., 1993, Generalized geologic map of the Arctic National Wildlife Refuge, northeastern Brooks Range, Alaska: Alaska Division of Geological \& Geophysical Surveys Special Report 42, 1 sheet, scale 1:500,000. Johnson, J.M., and Satake, Kenji, 1994, Rupture extent of the 1938 Alaska earthquake as inferred from tsunami waveforms: Geophysical Research Letters, v. 21, no. 9, p. 733-736. http://doi. org/10.1029/94GL00333

Johnson, J.M., Tanioka, Yuichiro, Ruff, L.J., Satake, Kenji, Kanamori, Hiroo, and Sykes, L.R., 1994, The 1957 great Aleutian earthquake: Pure and Applied Geophysics, v. 142, no. 1, p. 3-28.

Kaufman, D.S., 1986, Surficial geologic map of the Solomon, Bendeleben, and southern part of the Kotzebue quadrangles, western Alaska: U.S. Geological Survey Miscellaneous Field Studies Map MF-1838-A, 1 sheet, scale 1:250,000.

Kaufman, D.S., Calkin, P.E., Whitford, W.B., Przybyl, B.J., Hopkins, D.M., Peck, B.J., and Nelson, R.E., 1989, Surficial geologic map of the Kigluaik Mountains area, Seward Peninsula, Alaska: U.S. Geological Survey Miscellaneous Field Studies Map 2074, 1 sheet, scale 1:63,360.

Kelley, J.S., and Foland, R.L., 1987, Structural style and framework geology of the coastal plain and adjacent Brooks Range, in Bird, K.J., and Magoon, L.B, Petroleum Geology of the Northern Part of the Arctic National Wildlife Refuge, Northern Alaska: U.S. Geological Survey Bulletin 1778, p. 255-270. 
Kelley, T.E., 1961, Photogeology-A quick, economical tool for oil hunters: Oil and Gas Journal, Nov. 20, p. 265-272.

Kelley, T.E., 1963, Geology and hydrocarbons in Cook Inlet Basin, Alaska: American Association of Petroleum Geologists Memoir 2, p. 278-296.

Kelsey, H.M., Witter, R.C., Engelhart, S.E., Briggs, R., Nelson, A., Haeussler, P.J., and Corbett, D.R., 2015, Beach ridges as paleoseismic indicators of abrupt coastal subsidence during subduction zone earthquakes, and implications for Alaska-Aleutian subduction zone paleoseismology, southeast coast of the Kenai Peninsula, Alaska: Quaternary Science Reviews, v. 113, p. 147-158. http://doi. org/10.1016/j.quascirev.2015.01.006

Kirschner, C.E., and Lyon, C.A., 1973, Stratigraphic and tectonic development of Cook Inlet petroleum province, in Pitcher, M.G., ed., Arctic Geology: American Association of Petroleum Geologists Memoir 19, p. 396-407.

Koehler, R.D., 2013, Quaternary faults and folds (QFF): Alaska Division of Geological \& Geophysical Surveys Digital Data Series 3, http://maps.dggs. alaska.gov/qff. http://doi.org/10.14509/24956

Koehler, R.D., Reger, R.D., Spangler, R.R., and Hubbard, T.D., 2017, Assessment of geomorphology and geologic hazards in the Parks Highway-Minto Flats-Dalton Highway infrastructure corridor: Cook Inlet to Prudhoe Bay, Alaska: Report of Investigations 2016-X, Alaska, Division of Geological \& Geophysical Surveys.

Koehler, R.D., and Reger, R.D., 2011, Reconnaissance evaluation of the Lake Clark fault, Tyonek area, Alaska: Alaska Division of Geological \& Geophysical Surveys Preliminary Interpretive Report 2011-1, 8 p. http://doi.org/10.14509/22221

Koehler, R.D., and Woods, R.-E.F., 2013, Paleoseismic and LiDAR investigations along the Cathedral Rapids and Dot " $T$ " Johnson faults, interior Alaska: Alaska Division of Geological \& Geophysical Surveys Report of Investigation 2013-4, 21 p. http://doi.org/10.14509/26761

Koehler, R.D., Farrell, Rebecca-Ellen, Burns, P.A.C., and Combellick, R.A., 2012a, Quaternary faults and folds in Alaska_-A digital database, in Koehler,
R.D., Quaternary Faults and Folds (QFF): Alaska Division of Geological \& Geophysical Surveys Miscellaneous Publication 141, 31 p., 1 sheet, scale 1:3,700,000. http://doi.org/10.14509/23944 Koehler, R.D., Personius, S.F., Schwarz, D.P., Haeussler, P.J., and Seitz, G.G., 2011, A Paleoseismic study along the central Denali Fault, Chistochina Glacier area, south-central Alaska: Alaska Division of Geological \& Geophysical Surveys Report of Investigation 2011-1, 17 p. http://doi.org/10.14509/22361

Koehler, R.D., Reger, R.D., Carver, G.A., Spangler, E., and Gould, A., 2014, Castle Mountain fault, south-central Alaska-Observations on slip partitioning from lidar and paleoseismic trenching [abs.]: Geological Society of America Abstracts with Programs, v. 46, no. 6, abstract \#247276.

Koehler, R.D., Reger, R.D., and Frohman, R.A., 2012b, The Castle Mountain fault, south-central Alaska-New lidar-based observations on the sense of slip, Eos Trans. AGU, Fall Meet. Suppl., Abstract \#S53D-2530: Alaska Division of Geological \& Geophysical Surveys, 1 p., 1 sheet. http://doi. org/10.14509/24724

Koehler, R.D., Reger, R.D., Spangler, E.R. and Gould, A.I., 2016, Investigation of Active and potentially active faults along the route of the proposed Alaska Stand Alone Pipeline, Livengood to Cook Inlet, Alaska: Alaska Division of Geological \& Geophysical Surveys Report of Investigation 20154, 71 p. http://doi.org/10.14509/29409

Koehler, R.D., Schwarz, D.P., Rood, D.H., Reger, R.D., and Wolken, G.J., 2013, Preliminary paleoseismic observations along the central Denali fault, Alaska [poster], Eos Transactions AGU, Fall Meeting Supplement, Abstract \#T23C-2598, San Francisco, California, December 10, 2013: Alaska Division of Geological \& Geophysical Surveys, 1 sheet. http://doi.org/10.14509/26888

Kramer, S.L., 1996, Seismic hazard analysis_-Chapter 4, Geotechnical Earthquake Engineering: Upper Saddle River, NJ, Prentice Hall, p. 106-142.

Kulikov, E.A., Rabinovich, A.B., Fine, I.V., Bornhold, B.D., and Thomson, R.E., 1998, Tsunami generation by landslides at the Pacific coast of North America and the role of tides: Oceanology, v. 38, no. 3, p. 323-328. 
Lahr, J.C., Page, R.A., Fogleman, K.A., and Stephens, C.D., 1985, New evidence for activity on the Talkeetna segment, Castle Mountain-Caribou fault system-The 1984 Sutton earthquake, in Bartsch-Winkler, Susan, ed., The United States Geological Survey in Alaska-Accomplishments during 1984: U.S. Geological Survey Circular 967, p. 62-63.

Lahr, J.C., Page, R.A., Stephens, C.D., and Fogleman, K.A., 1986, Sutton, Alaska, earthquake of 1984Evidence for activity on the Talkeetna segment of the Castle Mountain fault system: Bulletin of the Seismological Society of America, v. 76, no. 4, p. 967-983.

Lander, J.F., 1996, Tsunamis affecting Alaska, 17371996: Boulder, CO, National Oceanic and Atmospheric Administration(NOAA)/National Geophysical Data Center (NGDC), Key to Geophysical Research Documentation, v. 31, 195 p.

Lathram, E.H., 1964, Apparent right-lateral separation on Chatham Strait fault, southeastern Alaska: Geological Society of America Bulletin, v. 75, no. 3, p. 249-252. http://doi.org/10.1130/00167606(1964)75[249:ARSOCS]2.0.CO;2

Lathram, E.H., 1965, Preliminary geologic map of northern Alaska: U.S. Geological Survey Open-File Report 65-96, 2 sheets, scale 1:1,000,000.

Lemke, R.W., 1967, Effects of the earthquake of March 27, 1964, at Seward, Alaska: U.S. Geological Survey Professional Paper 542-E, p. E1-E43, 2 sheets, scale 1:63,360.

Liberty, L.M., Finn, S.P., Haeussler. P.J., Pratt, T.L., and Peterson, Andrew, 2013, Megathrust splay faults at the focus of the Prince William Sound asperity, Alaska: Journal of Geophysical Research, Solid Earth, v. 118, no. 10, p. 5,428-5,441. http:// doi.org/10.1002/jgrb.50372

López, A.M., and Okal, E.A., 2006, A seismological reassessment of the source of the 1946 aleutian 'tsunami' earthquake, Geophysical Journal International, v. 165, p. 835-849.

MacKevett, E.M., Jr., 1978, Geologic map of the McCarthy Quadrangle, Alaska: U.S. Geological Survey Miscellaneous Investigations Series Map 1032, 1 sheet, scale 1:250,000.

Magoon, L.B., 1994, Petroleum resources in Alaska, in
Plafker, George, and Berg, H.C., eds., The Geology of Alaska: Boulder, CO, Geological Society of America, Geology of North America, v. G-1, p. 905-936.

Magoon, L.B., Adkinson, W.L., and Egbert, R.M., 1976, Map showing geology, wildcat wells, Tertiary plant fossil localities, K-Ar age dates, and petroleum operations, Cook Inlet area, Alaska: U.S. Geological Survey Miscellaneous Investigations Series Map I-1019, scale 1:250,000.

Matmon, A., Schwartz, D.P., Haeussler, P.J., Finke, R., Lienkaemper, J.J., Stenner, H.D., and Dawson, T.E., 2006, Denali fault slip rates and Holocenelate Pleistocene kinematics of central Alaska: Geology, v. 34, no. 8, p. 645-648. http://doi. org/10.1130/G22361.1

McCalpin, J.P., 2009, Paleoseismology, 2nd edition; International Geophysical Series, v. 95: Burlington, MA, Elsevier, 613 p.

McCalpin, J.P., Bruhn, R.L., Pavlis, T.L., Gutierrez, F., Guerrero, J., and Lucha, P., 2011, Antislope scarps, gravitational spreading, and tectonic faulting in the western Yakutat microplate, south coastal Alaska: Geosphere, v. 7, no. 5, p. 1,143-1,158. http://doi. org/10.1130/GES00594.1

Meigs, A.J., 1990, Structural geometry and sequence in the eastern Sadlerochit Mountains, northeastern Brooks Range, Alaska: Fairbanks, AK, University of Alaska Fairbanks, M.Sc. thesis.

Meigs, A.J., Johnston, Sarah, Garver, John, and Spotila, James, 2008, Crustal-scale structural architecture, shortening, and exhumation of an active, eroding orogenic wedge (Chugach/St. Elias Range, southern Alaska): Tectonics, v. 27, no. 4, TC4003, 26 p. http://doi.org/10.1029/2007TC002168

Mériaux, A.-S., Sieh, K., Finkel, R.C., Rubin, C.M., Taylor, M.H., Meltzner,, A.J., and Ryerson, F.J., 2009, Kinematic behavior of southern Alaska constrained by westward decreasing postglacial slip rates on the Denali Fault, Alaska: Journal of Geophysical Research, v. 114, no. B3, B03404. http://doi.org/10.1029/2007JB005053

Mertie, J.B., and Harrington, G.L., 1924, The RubyKuskokwim Region, Alaska: U.S. Geological Survey Bulletin 754, 129 p., 4 sheets, scale 1:250,000. 
Miller, D.J., 1960, The Alaska Earthquake of July 10, 1958-Giant wave in Lituya Bay: Bulletin of the Seismological Society of America, v. 50, no. 2, p. 253-266.

Moore, T.E., Potter, C.J., O’Sullivan, P.B., Shelton, K.L., and Underwood, M.B., 2004, Two stages of deformation and fluid migration in the west-central Brooks Range fold and thrust belt, northern Alaska, in Swennen, Rudy, Roure, François, and Granath, J.W., eds., Deformation, Fluid Flow, and Reservoir Appraisal in Foreland Fold and Thrust Belts: American Association of Petroleum Geologists Hedberg Series, no. 1, p. 157-186.

Morris, R.H., 1957, Reconnaissance study of the Marsh anticline, northern Alaska: U.S. Geological Survey Open File Report 57-0076, 6 p., 1 plate, no scale.

Mull, C.G., and Adams, K.E., 1989, Bedrock geology of the eastern Koyukuk Basin, central Brooks Range, and east-central Arctic Slope along the Dalton Highway, Yukon River to Prudhoe Bay, Alaska: Alaska Division of Geological \& Geophysical Surveys Guidebook 7, v. 1, 309 p., 1 sheet, scale 1 inch $=45$ miles. http://doi. org/10.14509/269

Mull, C.G., Glenn, R.K., and Adams, K.E., 1997, Tectonic evolution of the central Brooks Range mountain front-Evidence from the Atigun Gorge region: Journal of Geophysical Research, v. 102, no. B9, p. 20,749-20,772. http://doi. org/10.1029/96JB03732

Mull, C.G., Harris, E.E., Delaney, P.R., and Swenson, R.F., 2009, Geology of the Cobblestone CreekMay Creek area, east-central Brooks Range Foothills, Alaska: Alaska Division of Geological \& Geophysical Surveys Preliminary Interpretive Report 2009-5, 40 p., 1 sheet, scale 1:63,360. http://doi.org/10.14509/19661

Nicolsky, D.J., Suleimani, E.N., Haeussler, P.J., Ryan, H.F., Koehler, R.D., Combellick, R.A., and Hansen, R.A., 2013, Tsunami inundation maps of Port Valdez, Alaska: Alaska Division of Geological \& Geophysical Surveys Report of Investigation 2013-1, 77 p., 1 sheet, scale 1:12,500. http://doi. org/10.14509/25055
Nishenko, S.P., and Jacob, K.H., 1990, Seismic potential of the Queen Charlotte-Alaska-Aleutian seismic zone: Journal of Geophysical Research, v. 95, no. B3, p. 2,511-2,532. http://doi. org/10.1029/JB095iB03p02511

Nishenko, Stuart, Drury, Claire, and Milheizler, Jeff, 1998, Recent FEMA activities in earthquake risk analysis and mitigation, in Raufaste, N.J., Jr., ed., Wind and Seismic Effects-Proceedings of the 30th Joint Meeting of the U.S./Japan Cooperative Program in Natural Resources Panel on Wind and Seismic Effects, May 12-15, 1998, Gaithersburg, MD, NTIS document PB98150238, p. 300-305.

Okal, E.A., and Hebert, H., 2007, Far-field simulation of the 1946 Aleutian tsunami, Geophysical Journal International, v. 169, p. 1229-1238.

O’Sullivan, P.B., 1994, Fission track evidence indicates that the present-day Brooks range, Alaska is a Cenozoic, not Early Cretaceous physiographic feature [abs.]: Eos Transactions of the American Geophysical Union, v. 75, no. 44, Fall Meeting Supplement, 646.

O'Sullivan, P.B., and Wallace, W.K., 2002, Outof-sequence, basement-involved structures in the Sadlerochit Mountains region of the Arctic National Wildlife refuge, Alaska-Evidence and implications from fission-track thermochronology: Geological Society of America Bulletin, v. 114, no. 11, p. 1,356-1,378. http://doi.org/10.1130/00167606(2002) 114<1356:OOSBIS>2.0.CO;2

O'Sullivan, P.B., Wallace, W.K., and Murphy, J.M., 1998, Fission-track evidence for apparent out-ofsequence Cenozoic deformation along the Philip Smith Mountain front, northeastern Brooks Range, Alaska: Earth and Planetary Science Letters, v. 164, no. 3-4, p. 435-449. http://doi.org/10.1016/ S0012-821X(98)00237-4

Page, R.A., 1973, The Sitka Alaska Earthquake of 1972-An expected visitor: Earthquake Information Bulletin, U.S., no. 5, p. 4-9.

Page, R.A., Biswas, N.N., Lahr, J.C., and Pulpan, Hans, 1991, Seismicity of continental Alaska, in Slemmons, D.B., Engdahl, E.R., Zoback, M.D., and Blackwell, D.D., eds., Neotectonics of North of America (Decade Map edition): Boulder, CO, Geological Society of America, v. 1, p. 47-68. 
Parkin, E.J., 1969, Horizontal crustal movements determined from surveys after the Alaskan earthquake of 1964, in The Prince William Sound, Alaska, Earthquake of 1964 and Aftershocks; vol. III, Geodesy and Photogrammetry: Washington, DC, National Oceanic and Atmospheric Administration (NOAA) U.S. Coast and Geodetic Survey, p. 35-50.

Patton, W.W., Jr., 1973, Reconnaissance geology of the northern Yukon-Koyukuk Province, Alaska: U.S. Geological Survey Professional Paper 774-A, p. A1-A17.

Patton, W.W., Jr., and Hoare, J.M., 1968, The Kaltag fault, west-central Alaska, in U.S. Geological Survey, Geological Survey Research 1968, Chapter D: U.S. Geological Survey Professional Paper 600D, p. D147-D153.

Patton, W.W., Jr., and Miller, T.P., 1966, Regional geologic map of the Hughes Quadrangle, Alaska: U.S. Geological Survey Miscellaneous Geologic Investigations I-459, 1 sheet, 1:250,000 scale.

Patton, W.W., Jr., and Miller, T.P., 1973, Bedrock geologic map of Bettles and southern part of Wiseman quadrangles, Alaska: U.S. Geological Survey Miscellaneous Field Studies MF-492, 1 sheet, 1:250,000 scale.

Patton, W.W., Jr., Miller, T.P., and Tailleur, I.L., 1968, Regional geologic map of the Shungnak and southern part of the Ambler River quadrangles, Alaska: U.S. Geological Survey Miscellaneous Geologic Investigations I-554, 1 sheet, 1:250,000 scale.

Pavlis, T.L., Picornell, Carlos, Serpa, Laura, Bruhn, R.L., and Plafker, George, 2004, Tectonic processes during oblique collision-Insights from the St. Elias orogen, northern North American Cordillera: Tectonics, v. 23, no. 3, TC3001. http://doi. org/10.1029/2003TC001557

Perez, O.J., and Jacob, K.H., 1980, Tectonic model and seismic potential of the eastern Gulf of Alaska and Yakataga seismic gap: Journal of Geophysical Research, v. 85, no. B12, p. 7,132-7,150. http:// doi.org/10.1029/JB085iB12p07132

Personius, S.F., Crone, A.J., Burns, P.A.C., and Rozell, Ned, 2015, Paleoseismology of the Denali fault system at the Schist Creek site, central Alaska: U.S.
Geological Survey Open-File Report 2015-1225, 15 p., 1 oversize plate. http://doi.org/10.3133/ ofr20151225

Péwé, T.L., Wahrhaftig, Clyde, and Weber, F.R., 1966, Geologic map of the Fairbanks Quadrangle, Alaska: U.S. Geological Survey Miscellaneous Geologic Investigations Map 455, 5 p., 1 sheet, scale 1:250,000.

Péwé, T.L.,1975, Quaternary Geology of Alaska, U.S. Geological Survey Professional Paper 835

Plafker, George, 1967a, The Alaska Earthquake, March 27, 1964-Regional effects, surface faults on Montague Island: U.S. Geological Survey Professional Paper 543-G, p. G1-G42, 2 sheets, scale 1:31,680.

Plafker, George, 1967b, Geologic map of the Gulf of Alaska tertiary province, Alaska: U.S. Geological Survey Miscellaneous Geologic Investigations Map 484, 1 sheet, scale 1:500,000.

Plafker, George, 1969, Tectonics of the March 27, 1964, Alaska earthquake: U.S. Geological Survey Professional Paper 543-I, p. I1-I74, 2 sheets, scale 1:500,000.

Plafker, George, 1974, Preliminary geologic map of Kayak and Wingham Islands, Alaska: U.S. Geological Survey Open-File Report 74-82, 1 sheet, scale 1:31,680.

Plafker, George, and Berg, H.C., 1994, Review of the geology and tectonic evolution of Alaska, in Plafker, George, and Berg, H.C., eds., The Geology of Alaska: Boulder, CO, Geological Society of America, The Geology of North America, v. G-1, p. 989-1,021.

Plafker, George, and Thatcher, Wayne, 2008, Geological and geophysical evaluation of the mechanism of the great 1899 Yakutat Bay earthquakes, in Freymueller, J.T., Haeussler, P.J., Wesson, R.L., and Ekström, G., eds., Active Tectonics and Seismic Potential of Alaska: American Geophysical Union Geophysical Monograph Series, v. 179, p. 215-236. http://doi. org/10.1029/179GM12

Plafker, George, Detterman, R.L., and Hudson, R., 1975, New data on the displacement history of the Lake Clark fault, in Yount, M.E., ed., U.S. Geological Survey Alaska Program, 1975: U.S. Geological Survey Circular 722, p. 44-45. 
Plafker, George, Gilpin, L.M., and Lahr, J.C., 1994a, Neotectonic map of Alaska, in Plafker, George, and Berg, H.C., eds., The Geology of Alaska: Boulder, CO, Geological Society of America, The Geology of North America, v. G1, Plate 12, 1 sheet with text, scale 1:2,500,000.

Plafker, George, Hudson, T.L., Bruns, Terry, and Rubin, Meyer, 1978, Late Quaternary offsets along the Fairweather fault and crustal plate interactions in southern Alaska: Canadian Journal of Earth Sciences, v. 15, no. 5, p. 805-816. http://doi. org/10.1139/e78-085

Plafker, George, Hudson, T.L., and Richter, D.H., 1977, Preliminary observations on late Cenozoic displacements along the Totschunda and Denali fault system, in Blean, K.M., ed., The United States Geological Survey in Alaska-Accomplishments during 1976: U.S. Geological Survey Circular 751-B, p. B67-B69.

Plafker, George, Hudson, T.L., Rubin, M., and Dixon, K.L., 1982, Holocene marine terraces and uplift history in the Yakataga seismic gap near Icy Cape, Alaska, in Coonrad, W.L., ed., U.S. Geological Survey Alaska Accomplishments during 1980: U.S. Geological Survey Circular 844, p. 111-115. Plafker, George, Moore, J.C., and Winkler, G.R., 1994b, Geology of the southern Alaska margin, in Plafker, George, and Berg, H.C., eds., The Geology of Alaska: Boulder, CO, Geological Society of America, Geology of North America, v. G-1, p. 389-449.

Plesch, A., Shaw, J.H., Benson, C., Bryant, W.A., Carena, S., Cooke, M., Dolan, J., Guis, G., Gath, E., Grant, L., Hauksson, E., Jordan, T.H., Kamerling, M., Legg, M., Lindvall, S., Magistrale, H., Nicholson, C., Niemi, N., Oskin, M., Perry, S., Planansky, G., Rockwell, T., Shearer, P., Sorlien, C., Süss, M.P., Suppe, J., Treiman, J., Yeats, R., 2007, Community fault model (CFM) for Southern California, Bulletin of the Seismological Society of America, v. 97, p. 1,793-1,802. http://doi. org/10.1785/0120050211

Praet, N., Moernaut, J., Van Daele, M., Boes, E., Haeussler, P.J., Strupler, M., Schmidt, S., Loso, M.G., and De Batist, M., 2017, Paleoseismic potential of sublacustrine landslide records in a high-seismicity setting (south-central Alaska), Marine Geology, v. 384, p. 103-119.

Ratchkovski, N.A., and Hansen, R.A., 2002, New constraints on tectonics of interior AlaskaEarthquake locations, source mechanisms, and stress regime: Bulletin of the Seismological Society of America, v. 92, no. 3, p. 998-1,014. http://doi. org/10.1785/0120010182

Reed, B.L., and Nelson, S.W., 1980, Geologic map of the Talkeetna Quadrangle, Alaska: U.S. Geological Survey Miscellaneous Investigations Series Map 1174, 15 p., 1 sheet, scale 1:250,000.

Reifenstuhl, R.R., Dover, J.H., Newberry, R.J., Clautice, K.H., Liss, S.A., Blodgett, R.B., Bundtzen, T.K., and Weber, F.R., 1997, Interpretive geologic bedrock map of the Tanana B-1 Quadrangle, central Alaska: Alaska Division of Geological \& Geophysical Surveys Report of Investigation 9715B, 15 p., 1 sheet, scale 1:63,360. http://doi. org/10.14509/2552

Reiter, Leon, 1990, Earthquake hazard analysisIssues and insights: New York, NY, Columbia University Press, $254 \mathrm{p}$.

Reiter, Leon, 1995, Paleoseismology-A user's perspective, in Serva, Laura, and Slemmons, D.B., eds., Perspectives in Paleoseismology: Association of Engineering Geologists Special Publication, v. 6, p. 3-6.

Richter, D.H., 1976, Geologic map of the Nabesna Quadrangle, Alaska: U.S. Geological Survey Miscellaneous Investigations Series Map I-932, 1 sheet, 1:250,000 scale.

Richter, D.H., and Matson, N.A., Jr., 1971, Quaternary faulting in the eastern Alaska Range: Geological Society of America Bulletin, v. 82, no. 6, p. 1,529-1,540. http://doi.org/10.1130/00167606(1971)82[1529:QFITEA]2.0.CO;2

Ruppert, N.A., Ridgway, K.D., Freymueller, J.T., Cross, R.C., and Hansen, R.A., 2008, Active tectonics of interior Alaska-Seismology, GPS geodesy, and local geomorphology, in Freymueller, J.T., Haeussler, P.J., Wesson, R.L., and Ekström, G., eds., Active Tectonics and Seismic Potential of Alaska: American Geophysical Union Geophysical Monograph Series, v. 179, p. 109-133. http://doi. org/10.1029/179GM06 
Ryan, H.F., and Scholl, D.W., 1993, Geologic implications of great interplate earthquakes along the Aleutian Arc: Journal of Geophysical Research, v. 98 , no. B12, p. 22,135-22,146. http://doi. org/10.1029/93JB02451

Ryan, H.F., Lee, H.J., Haeussler, P.J., Alexander, C.R., and Kayen, R.E., 2010, Historic and paleosubmarine landslide deposits imaged beneath Port Valdez, Alaska-Implications for tsunami generation in a glacial fiord, in Mosher, D.C., Shipp, C., Moscardelli, L., Chaytor, J., Baxter, C., Lee, H., and Urgeles, R., eds., Submarine Mass Movements and their Consequences: Springer Science + Business Media B.V., Advances in Natural and Technological Hazards Research, v. 28, p. 411-421.

Sainsbury, C.L., 1972, Geologic map of the Teller Quadrangle, western Seward Peninsula, Alaska: U.S. Geological Survey Miscellaneous Geologic Investigations Map 685, 4 p., 1 sheet, scale 1:250,000.

Sauber, Jeanne, McClusky, Simon, and King, Robert, 1997, Relation of ongoing deformation rates to the subduction zone process in southern Alaska: Geophysical Research Letters, v. 24, no. 22, p. 2,853-2,856. http://doi.org/10.1029/97GL52979

Schmoll, H.R., and Yehle, L.A., 1987, Surficial geologic map of the northwestern quarter of the Tyonek A-4 Quadrangle, south-central Alaska: U.S. Geological Survey Miscellaneous Field Studies Map MF-1934, scale 1:31,680, 1 sheet.

Schwartz, D.P., 2006, A look back at 1906Perspectives on great earthquakes and postearthquake investigations: Seismological Research Letters, v. 77, no. 2, p. 123-127. http://doi. org/10.1785/gssrl.77.2.123

Schwartz, D.P., and others, in review, Field data and preliminary interpretations at four paleoseismic sites on the western Denali fault, Alaska: U.S. Geological Survey Open-file Report 2013-XXXX.

Schwartz, D.P., Dawson, T.E., Haeussler, P.J., Lienkaemper, J.J., Matmon, A., Stenner, H.D., Sherrod, Brian, Cinti, F.R., Montone, P., Carver, G.A., and Plafker, George, 2003, Paleoearthquakes on the Denali-Totschunda fault systemPreliminary observations of slip and timing:
American Geophysical Union, fall meeting, abstract \#S11B-03.

Schwartz, D.P., Haeussler, P.J., Seitz, G.G., and Dawson, T.E., 2012, Why the 2002 Denali fault rupture propagated onto the Totschunda faultImplications for fault branching and seismic hazards: Journal of Geophysical Research, v. 117, no. B11, B11304. http://doi.org/10.1029/2011JB008918 Schwartz, D.P., Haeussler, P.J., Seitz, G.G., Koehler, R.D., Personius, S.F., Crone, A.J., and Dawson, T.E., 2014, Recurrence of large earthquakes along the Denali fault system [abs.]: Seismological Society of America Annual Meeting, Seismological Research Letters, v. 85, no. 2, p. 474.

Seitz, G.J., Haeussler, P.J., Crone, A.J., Lipovsky, P.S., and Schwartz, D.P., 2008, Eastern Denali fault slip rate and paleoseismic history, Kluane lake area, Yukon Territory, Canada [abs.]: Eos Transactions American Geophysical Union, v. 89, no. 53, Fall Meeting Supplement, Abstract T53B-1947.

Shennan, Ian, Bruhn, Ronald, and Plafker, George, 2009, Multi-segment earthquakes and tsunami potential of the Aleutian megathrust: Quaternary Science Reviews, v. 28, no. 1-2, p. 7-13. http:// doi.org/10.1016/j.quascirev.2008.09.016

Shennan, Ian, Bruhn, Ronald, Barlow, Natasha, Good, Kelly, and Hocking, Emma, 2014, Late Holocene great earthquakes in the eastern part of the Aleutian megathrust: Quaternary Science Reviews, v. 84, p. 86-97. http://doi.org/10.1016/j. quascirev.2013.11.010

Slemmons, D.B., and McKinney, Roy, 1977, Definition of "Active Fault" final report: U.S. Army Corps of Engineers Waterways Experiment Station Miscellaneous Paper S-77-8, 22 p.

Snay, R.A., Freymueller, J.T., and Pearson, Chris, 2013, Crustal motion models developed for version 3.2 of the horizontal time-dependent positioning utility: Journal of Applied Geodesy, v. 7, p. 173190. http://doi.org/10.1515/jag-2013-0005

Somerville, P.G., and Moriwaki, Yoshi, 2003, Seismic hazards and risk assessment in engineering practice, in Lee, W.H.K., Kanamori, Hiroo, Jennings, P.C., and Kisslinger, Carl, eds., International Handbook of Earthquake and Engineering Seismology, part B, p. 1,065-1,080. 
Sonnevil, R.A., 1981, The Chilkat-Prince of Wales plutonic province, southeastern Alaska, in Albert, N.R.D., and Hudson, T.L., eds., The United States Geological Survey in Alaska-Accomplishments during 1979: U.S. Geological Survey Circular 823-B, p. B112-B115.

St. Amand, Pierre, 1957, Geological and geophysical synthesis of the tectonics of portions of British Columbia, the Yukon Territory, and Alaska: Geological Society of America Bulletin, v. 68, no. 10, p. 1,343-1,370.

Suleimani, E.N., Nicolsky, D.J., West, D.A., Combellick, R.A., and Hansen, R.A., 2010, Tsunami inundation maps of Seward and northern Resurrection Bay, Alaska: Alaska Division of Geological \& Geophysical Surveys Report of Investigation 2010-1, 47 p., 3 sheets, scale 1:12,500. http://doi.org/10.14509/21001

Tape, C.M., Silwal, Vipul, Ji, Chen, Keyson, Laura, West, M.E., and Ruppert, Natalia, 2015, Transtensional tectonics of the Minto Flats fault zone and Nenana Basin, central Alaska: Bulletin of the Seismological Society of America, v. 105, no. 4, p. 2,081-2,100. http://doi. org/10.1785/0120150055

Tape, C.M., West, M.E., Silwal, Vipul, and Ruppert, Natalia, 2013, Earthquake nucleation and triggering on an optimally oriented fault: Earth and Planetary Science Letters, v. 363, p. 231-241. http://doi.org/10.1016/j.epsl.2012.11.060

Tarr, R.S., Martin, Lawrence, and Gilbert, G.K., 1912, The earthquakes at Yakutat Bay, Alaska, in September, 1899; with a preface by G.K. Gilbert: U.S. Geological Survey Professional Paper 69, 135 p., 3 sheets, scale 1:5,000,000.

Taylor, T.P., and Bemis, S.P., 2012, Paleoseismology of the Denali fault at the Nenana River, Abstract T11A-2551: American Geophysical Union Fall Meeting, San Francisco, CA, December 3-7, 2012. Ten Brink, N.W., and Waythomas, C.F., 1985, Late Wisconsin glacial chronology of the north-central Alaska Range-A regional synthesis and its implication for early human settlements, in Powers, W.R., ed., North Alaska Range Early Man Project:
National Geographic Society Research Reports, v. 19 , p. 15-32.

Thorson, R.M., 1979, Recurrent Late Quaternary faulting near Healy, Alaska, in Alaska Division of Geological \& Geophysical Surveys, Short Notes on Alaskan Geology 1978: Alaska Division of Geological \& Geophysical Surveys Geologic Report 61C, p. 10-14. http://doi.org/10.14509/410

Tocher, Don, 1960, The Alaska earthquake of July 10, 1958-Movement on the Fairweather fault and field investigation of southern epicentral region: Bulletin of the Seismological Society of America, v. 50, no. 2, p. 267-292.

U.S. Nuclear Regulatory Commission (NRC), 1997, Part 100, Reactor Site Criteria, Subpart B, Appendix A to Part 100, III. Definitions (c). http://www.nrc.gov/reading-rm/doc-collections/ cfr/part100/full-text.html

Wahrhaftig, Clyde, 1958, Quaternary geology of the Nenana River valley and adjacent parts of the Alaska Range: U.S. Geological Survey Professional Paper 293-A, 118 p.

Wallace, W.K., 2008a, Chapter 2, Mechanical stratigraphy and the structural geometry and evolution of the central and eastern foothills of the Brooks Range, northern Alaska, in Hanks, C.L., Unraveling the timing of fluid migration and trap formation in the Brooks Range foothills_-A key to discovering hydrocarbons: Final Report to United States Department of Energy, National Energy Technology Laboratory, DOE Award No. DE-FC236-06NT41248.

Wallace, W.K., 2008b, Yakataga fold and thrust beltStructural geometry and tectonic implications of a small continental collision zone, in Freymueller, J.T., Haeussler, P.J., Wesson, R.L., and Ekström, G., eds., Active Tectonics and Seismic Potential of Alaska: American Geophysical Union Geophysical Monograph 179, p. 237-256. http://doi. org/10.1029/179GM13

Wallace, W.K., and Hanks, C.L., 1990, Structural provinces of the northeastern Brooks Range, Arctic National Wildlife Refuge, Alaska: American Association of Petroleum Geologists Bulletin, v. 74, no. 7 , p. 1,100-1,118. 
Weber, F.R., and Foster, H.L., 1982, Tertiary(?) conglomerate and Quaternary faulting in the Circle Quadrangle, Alaska, in Coonrad, W.L., ed., The U.S. Geological Survey in AlaskaAccomplishments during 1980: U.S. Geological Survey Circular 844, p. 58-60.

Weber, F.R., Wheeler, K.L., Rinehart, C.D., Chapman, R.M., and Blodgett, R.B., 1992, Geologic map of the Livengood Quadrangle, Alaska: U.S. Geological Survey Open-File Repot 92-562, 20 p., 1 sheet, scale 1:250,000.

Wesnousky, S.G., 1986, Earthquakes, Quaternary faults, and seismic hazard in California: Journal of Geophysical Research, v. 91, no. B12, p. 12,587-12,631. http://doi.org/10.1029/ JB091iB12p12587

Wesson, R.L., Boyd, O.S., Mueller, C.S., Bufe, C.G., Frankel, A.D., and Petersen, M.D., 2007, Revision of time-independent probabilistic seismic hazard maps for Alaska: U.S. Geological Survey OpenFile Report 2007-1043. http://pubs.usgs.gov/ of/2007/1043/

Wesson, R.L., Frankel, A.D., Mueller, C.S., and Harmsen, S.C., 1999, Probabilistic seismic hazard maps of Alaska: U.S. Geological Survey Open-File Report 99-36, 43 p.

West, M., Gardine, M., Ruppert, N., Tape, C., Holtkamp, S., Freymueller, J., and Abers, G., 2016, Perspectives on the $M_{W} 7.1$ Iniskin earthquake, [abs.] Seismological Society of America 2016 Annual Meeting, Reno, NV, April 20-22, 2016

Willis, J.B., Haeussler, P.J., Bruhn, R.L., and Willis, G.C., 2007, Holocene slip rate for the western segment of the Castle Mountain fault, Alaska: Bulletin of the Seismological Society of America, v. 97, no. 3, p. 1,019-1,024.

Witter, R.C., LeWinter, A., Bender, A., Glennie, C., and Finnegan, D., 2017a, Sculpted by water, elevated by earthquakes: the coastal landscape of Glacier Bay National Park, Alaska, U.S. Geological Survey General Information Product 177.

Witter, R.C., Scharer, K., DuRoss, C.B., Bender, A.M., Haeussler, P.J., and Lease, R., 2017b, Evidence for prehistoric earthquakes on the southern Fairweather fault in trenches across the 1958 surface rupture, Glacier Bay National Park,
Alaska, [abs.], Seismological Society of America 2017 Annual Meeting, Denver, CO, April 18-20, 2017.

Witter, R.C., Briggs, R.W., Koehler, R.D., Gelfenbaum, G.R., Engelhart, S.E., Nelson, A.R., Carver, G.A., Bender, A.M., and Hemphill-Haley, Eileen, 2014a, Evidence for high tsunamis in the Fox Islands implies repeated Aleutian megathrust earthquakes in the Unalaska seismic gap: Seismological Society of America, Annual Meeting, Anchorage, AK, April 30-May 2, 2014, Abstracts with Programs, v. 85, no. 2 , p. 442.

Witter, R.C., Carver, G.A., Briggs, R.W., Gelfenbaum, G.R., Koehler, R.D., La Selle, S.P., Bender, A.M., Engelhart, S.E., and Hemphill-Haley, Eileen, 2015, Unusually large tsunamis frequent a currently creeping part of the Aleutian megathrust: Geophysical Research Letters, v. 43, no. 1, p. 76-84. http://doi.org/10.1002/2015GL066083

Witter, R.C., Briggs, R.W., Koehler, R.D., Gelfenbaum, G.R., Engelhart, S.E., Nelson, A.R., Carver, G.A., Bender, A.M., and Hemphill-Haley, Eileen, 2014b, Little late Holocene strain accumulation and release on the Aleutian megathrust below the Shumagin Islands, Alaska: Geophysical Research Letters, v. 41, no. 7, p. 2,359-2,367. http://doi. org/10.1002/2014GL059393

Worthington, L.L., Gulick, S.P.S., and Pavlis, T.L, 2010, Coupled stratigraphic and structural evolution of a glaciated orogenic wedge, offshore St. Elias Orogen, Alaska: Tectonics, v. 29, no. 6, TC6013. http://doi.org/10.1029/2010TC002723 Wright, T.J., Lu, Zhong, and Wicks, Chuck, 2003, Source model for the $\mathrm{M}_{\mathrm{W}}$ 6.7, 23 October 2002, Nenana Mountain earthquake (Alaska) from InSAR: Geophysical Research Letters, v. 30, no. 18. http://doi.org/10.1029/2003GL018014

Yeats, Robert, 2012, Chapter 2, Alaska, Canada, Cascadia, and eastern North America, in Yeats, Robert, ed., Active faults of the world: New York, Cambridge University Press, 634 p.

Youngs, R.R., and Coppersmith, K.J., 1985, Implications of fault slip rates and earthquake recurrence models to probabilistic seismic hazard estimates: Bulletin of the Seismological Society of America, v. 75, no. 4, p. 939-964. 